Universidad de Lima

Escuela de Posgrado

Maestría en Tributación y Política Fiscal

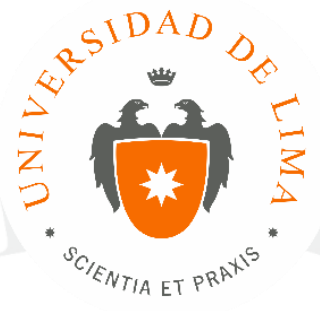

\title{
TRATAMIENTO TRIBUTARIO PARA EFECTOS DEL IMPUESTO A LA RENTA DE LOS GASTOS DE PROSPECCIÓN Y EXPLORACIÓN MINERA EFECTUADOS ANTES DEL INICIO DE LA ETAPA PRODUCTIVA
}

Trabajo de investigación para optar el Grado Académico de Maestro en

Tributación y Política Fiscal

Gisela Arroyo Langschwager

19970134

Asesor Walker Villanueva Gutiérrez

Lima - Perú

Noviembre de 2017 


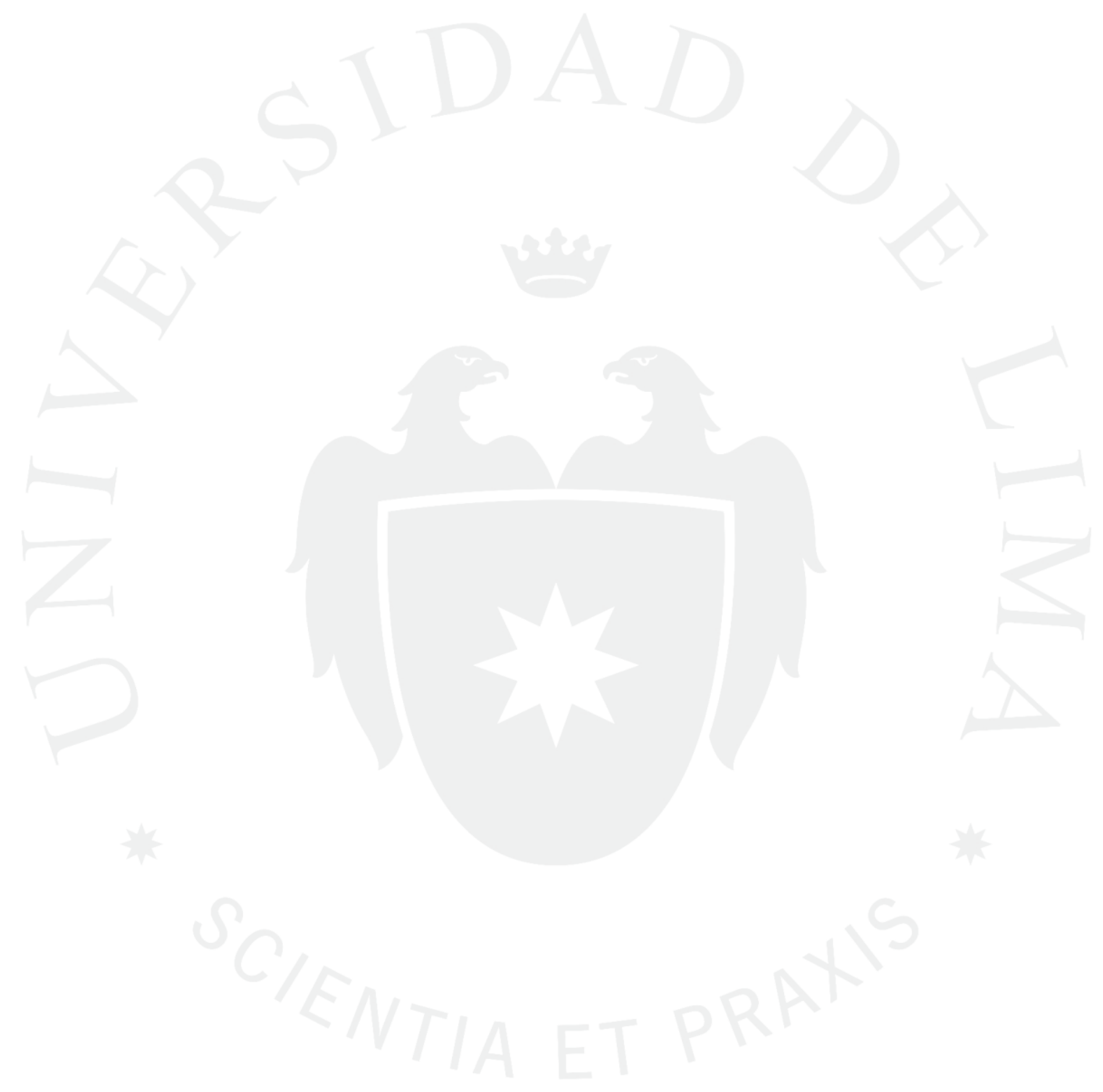




\section{TRATAMIENTO TRIBUTARIO PARA}

\section{EFECTOS DEL IMPUESTO A LA RENTA DE}

LOS GASTOS DE PROSPECCIÓN Y

EXPLORACIÓN MINERA EFECTUADOS

ANTES DEL INICIO DE LA ETAPA

PRODUCTIVA 
A mis padres, que hicieron lo posible, lo imposible y lo extra-ordinario por mi educación. No hay mejor legado. 


\section{TABLA DE CONTENIDO}

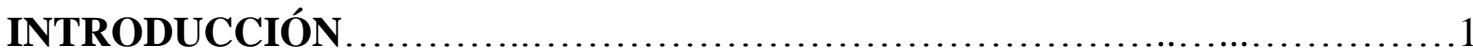

CAPÍTULO I: NOCIÓN DE GASTOS DE PROSPECCIÓN Y EXPLORACIÓN MINERA EFECTUADOS ANTES DEL INICIO DE LA ETAPA

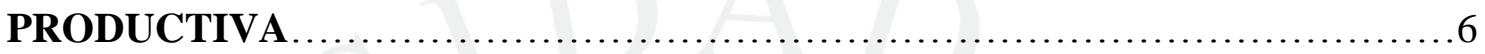

CAPÍTULO II: MARCO NORMATIVO TRIBUTARIO APLICABLE...........10

CAPÍtULO III: EL “GASTO DE PROSPECCIÓN Y EXPLORACIÓN MINERA" REGULADO POR LA NORMA TRIBUTARIA

3.1 Artículo $74^{\circ}$ de la Ley General de Minería: ¿gasto o inversión?..................14

3.1.1 Aplicación de la norma tributaria sobre "activos"...................... 16

3.1.2 Aplicación de la norma tributaria sobre "activos fijos".................. 19

3.1.3 Corolario............................................................. 28

3.2 Alcance del concepto de "prospección y exploración" y sus diferencias con otro tipo de gastos pre operativos................................... 28

3.2.1 Gastos preoperativos generales................................... 30

3.2.2 Gastos de desarrollo............................................... 34

3.2.3 Gastos de cateo................................................. 36

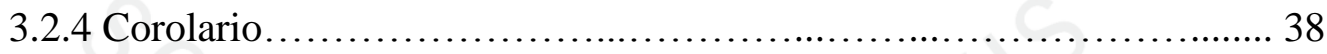

CAPÍTULO IV: OPCIONES PREVISTAS POR LA NORMA TRIBUTARIA PARA LA DEDUCCIÓN DE LOS GASTOS DE PROSPECCIÓN Y EXPLORACIÓN MINERA ANTES DEL INICIO DE LA ETAPA

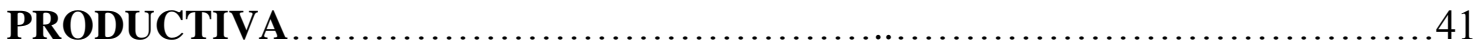

4.1 Generalidades sobre la deducción de gastos efectuados en etapas

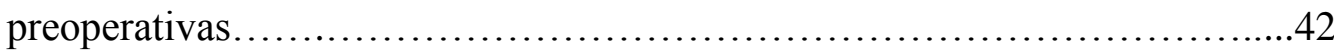

4.2 Primera opción: Amortización del gasto.............................49

4.2.1 La amortización tributaria: concepto y fines......................50 
4.2.2 Producción mínima obligatoria (PMO) .52

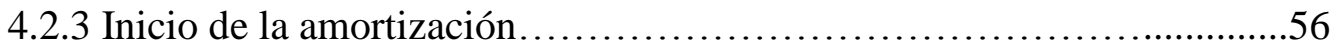

4.2.4 Plazo de la amortización...........................................60

4.2.5 Método de amortización.................................................66

4.3 Segunda opción: Deducción del gasto en el ejercicio en que se

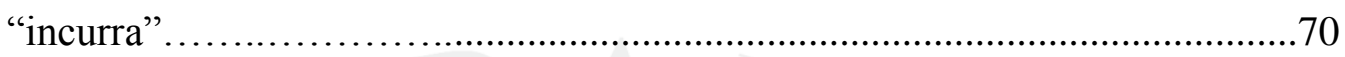

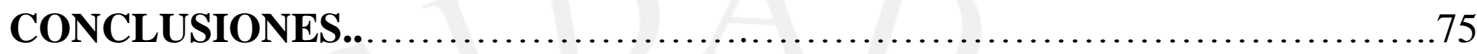

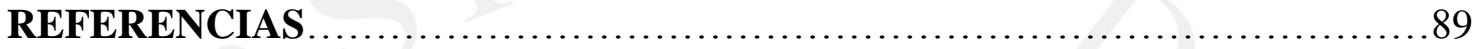

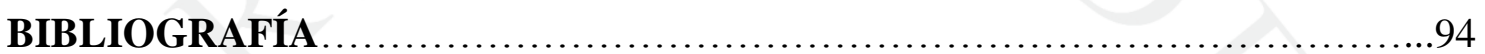




\section{ÍNDICE DE TABLAS}

Tabla 3.1. Diferencias entre el tratamiento tributario de los gastos de prospección y exploración y los gastos preoperativos generales................................................32

Tabla 3.2. Diferencias entre el tratamiento tributario de los gastos de prospección y

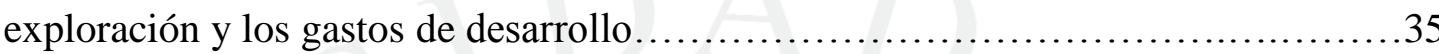




\section{INTRODUCCIÓN}

El tratamiento tributario aplicable a las inversiones en prospección y exploración minera resulta de especial importancia para el inversionista que apuesta por iniciar y desarrollar un proyecto minero. Nos referimos a las inversiones iniciales destinadas a determinar la existencia o no del mineral, su volumen, características, y en base a ello, la viabilidad de su explotación. Este tipo de inversiones implican un altísimo riesgo, tanto por la incertidumbre en torno a su éxito o viabilidad, así como por tratarse de montos bastante significativos desde un punto de vista económico. En este contexto, factores como la seguridad jurídica, la certidumbre en el tratamiento de dichos desembolsos y la garantía del retorno de la inversión resultan fundamentales. Debe tenerse en consideración que las inversiones efectuadas durante una etapa preproductiva no tienen un correlato con ingreso alguno pues tales ingresos sólo se generarán una vez que inicie la explotación del yacimiento, si es que este resulta viable.

Consideramos que la política tributaria en materia minera debe tener como objetivo lograr ingresos que permitan al Estado sostener sus cargas públicas, pero también brindar al inversionista un sistema fiscal atractivo que ofrezca seguridad jurídica y predictibilidad de las reglas de juego, de manera que se consiga competitividad internacional en la atracción de inversiones en exploración que aseguren la continuidad de dicha actividad tan importante para el desarrollo nacional y de esa forma a su vez se garantice la generación de futuros ingresos para el Estado.

La inversión en un país resultará más atractiva mientras exista menor riesgo en el retorno de la inversión y mayor seguridad y certidumbre jurídica. Si bien en el Perú hemos venido utilizando los Contratos Ley como instrumento para garantizar la seguridad jurídica al inversionista minero, es cierto también que esta estabilidad se mengua cuando el régimen estabilizado o el tratamiento tributario específico establecido para el sector no es claro, crea incertidumbre, o genera distintos criterios en su interpretación y aplicación.

Consideramos indispensable para que un régimen sea atractivo al inversionista, el tener normas claras que otorguen una mínima seguridad jurídica que además permita 
garantizar el rendimiento de su inversión bajo reglas que no cambien o permanezcan en sustancia a lo largo del tiempo, sea tanto por las posibles modificaciones legislativas como por la variación en la interpretación o aplicación de las mismas por parte del fisco.

Es así que el tratamiento tributario de los gastos de prospección y exploración toma especial importancia para la inversión minera, pues será un factor que influirá en la decisión de invertir y en la posibilidad de recuperar la inversión a futuro.

Por un lado, se requiere un tratamiento tributario que permita su deducción contra los ingresos que se generen en caso la inversión resulte exitosa o genere incentivos para continuar con la misma, o en todo caso, se posibilite la recuperación de los créditos acumulados o escudos fiscales generados en caso la inversión sea infructuosa. De otro lado, será un factor también el grado de certeza o seguridad jurídica que el inversionista tenga en relación al tratamiento tributario de los gastos de prospección y exploración, seguridad que sólo podrán ofrecer normas claras, que no resulten ambiguas en su aplicación ni que se encuentren sujetas a cambios de interpretación.

El tratamiento tributario aplicable a los gastos de prospección y exploración minera antes de la etapa productiva, se encuentra regulado en el artículo $74^{\circ}$ del Decreto Supremo N 014-92-EM, Texto Único Ordenado de la Ley General de Minería (en adelante "LGM"), norma que ha resultado desfasada en el tiempo y cuyo texto actual se mantiene sin mayor alteración hace casi treinta años desde la promulgación en 1981 del Decreto Legislativo $109^{\circ}$.

Las normas vigentes en esta materia no se condicen ni reflejan la realidad de un país que tiene como uno de sus principales impulsores de desarrollo al sector minero y cuyo dinamismo, variedad y complejidad ha sobrepasado las consideraciones planteadas inicialmente por el legislador. Recordemos que dichas normas fueron promulgadas en un escenario muy distinto al actual, en el que la experiencia e inversión en minería resultaba mínima en comparación a la existente al día de hoy. En efecto, tenemos que en 1981 la inversión en minería ascendía a un aproximado de US\$ 400 millones, mientras que en el 2013 dicha inversión alcanzó un monto máximo de inversión de US\$ 9,719 millones (Sociedad Nacional de Minería, Petróleo y Energía [SNMPE], 2016). 
Asimismo, a lo largo de los años hemos sido testigos de los diversos criterios interpretativos y discrepancias en la aplicación de las normas que regulan el tratamiento tributario de los gastos de exploración, así como actuaciones del fisco tendientes a desconocer la deducción de dichos gastos para la determinación del Impuesto a la Renta. De igual modo, hemos visto pronunciamientos y posiciones adoptadas por los órganos administrativos en materia fiscal que en muchos casos han resultado desproporcionados, excesivamente restrictivos o carentes de fundamento.

El presente trabajo pretende efectuar un análisis de la normativa tributaria vigente que regula la deducción del Impuesto a la Renta de los gastos de prospección y exploración efectuados en el sector minero antes de la etapa productiva. Asimismo, tiene como objetivo revisar los diversos criterios interpretativos existentes en relación a dichas normas, así como las contingencias tributarias para su deducción.

De igual forma, pretende efectuar un análisis de la legislación vigente a fin de sugerir precisiones o modificaciones que permitan otorgar claridad y predictibilidad de las reglas de juego, y de esa manera optimizar la normativa tributaria en aras de la mejora de la competitividad del sector dando prevalencia a mecanismos tributarios que permitan incentivar la inversión en exploración.

Consideramos que este análisis en torno al asunto propuesto, toma vital importancia en la época actual, considerando que a criterio de muchos atravesamos por el denominado "fin del superciclo de los commodities" (Red Latinoamericana sobre las Industrias Extractivas, 2016). Muestra de ello es que la inversión en exploración minera se ha reducido sustancialmente, haciéndose necesarios mecanismos que impulsen o incentiven la inversión en actividades de exploración que, a su vez, garanticen futuros ingresos y el mantenimiento a futuro de las arcas fiscales.

Como lo ha reportado el Organismo Supervisor de la Inversión en Energía y Minas [OSINERGMIN], (2016), la disponibilidad de las reservas mineras y de las futuras explotaciones en el sector dependen de la inversión en exploración minera, la misma que ha venido disminuyendo año a año después de alcanzar cifras record en el 2012 (p. 7). En el 2015 la inversión en exploración llegó a un total de US\$ 439.8 millones, lo que significó una caída de $28.6 \%$ en relación al año 2014 (Instituto de Ingenieros de Minas del Perú, 2016). De igual manera, sólo entre el 2015 y el 2016 la inversión minera en exploración disminuyó un 46\% [SNMPE], 2017). 
Asimismo, de acuerdo a lo señalado por el Survey of Mining Companies elaborado por el Instituto Fraser, el Perú ha caído diez puestos en el Índice de Atracción de Inversiones (del puesto 26 al 36). Si bien el principal motivo de esta caída en la percepción de los inversionistas mineros reside en los conflictos sociales, inciden también factores tales como incertidumbre en cuanto a la interpretación y aplicación de las regulaciones existentes y el régimen de tributación, considerados como elementos que no fomentan la inversión (Lampadia, 2016).

Esta coyuntura se explica por varios factores que han producido que los inversionistas mineros efectúen recortes significativos en inversiones destinadas a las actividades de exploración. Entre estos factores tenemos la caída continua del precio de los minerales, la paralización de proyectos por conflictos sociales y la dificultad para conseguir los permisos y concluir los trámites necesarios para iniciar proyectos, inclusive de exploración, así como los altos costos operativos y de capital y la incertidumbre en la demanda de commodities.

Debemos tener presente que sólo manteniendo la inversión en exploración es posible asegurar un crecimiento sostenido en la minería con el descubrimiento de nuevos yacimientos y su explotación.

En suma, consideramos que la mejora en la competitividad del sector minero peruano mediante la instauración de un régimen tributario que otorgue seguridad jurídica en su aplicación, así como claridad y predictibilidad en interpretación, y asimismo que garantice y no obstaculice la rentabilidad de las operaciones mineras, constituye un factor importante para la atraer inversiones en exploración y garantizar la continuidad de las operaciones mineras en el país y su consecuente beneficio a las arcas fiscales y el desarrollo nacional.

El tratamiento de los gastos de prospección y exploración como inversión inicial para el desarrollo de un proyecto, tiene importantes efectos en relación al rendimiento esperado por el inversionista debido a que la inversión en exploración no sólo es significativa económicamente, sino que indispensable para el desarrollo de la actividad minera por lo que necesita ser viable. No habrá desarrollo de minería productiva sin proyectos de exploración, de manera que el tratamiento tributario de los gastos de prospección y exploración, la seguridad jurídica en su interpretación y aplicación, así como normas que incentiven estas inversiones, resultarán importantes para el desarrollo 
de la actividad minera y por ende, para el desarrollo del país.

Finalmente, como parte del desarrollo del presente trabajo y a modo de conclusión, consideramos relevante plantear alternativas legislativas que permitan modernizar y optimizar la legislación nacional en aras de la mejora de la competitividad del sector y el otorgamiento de una mayor seguridad jurídica al inversionista minero. 


\section{CAPÍTULO I: NOCION DE GASTOS DE PROSPECCIÓN Y EXPLORACIÓN MINERA EFECTUADOS ANTES DEL INICIO DE LA ETAPA PRODUCTIVA}

La actividad minera es una actividad que se desarrolla en diversas etapas o fases a lo largo del tiempo pues para llegar a la explotación del yacimiento y a una etapa productiva será necesario desarrollar varias etapas previas que exigirán distintos tipos de inversión, desde aquellas vinculadas a la adquisición del título de la concesión, el descubrimiento y dimensionamiento del yacimiento minero, la construcción de socavones o tajos, campamentos y todas las instalaciones y autorizaciones necesarias para extraer y comercializar el mineral.

Cada una de estas etapas tiene una finalidad específica que debe ser cumplida antes de continuar con la siguiente. Las etapas de la actividad minera son las siguientes:

- Prospección y exploración

- Desarrollo y preparación

- Producción

- Cierre y postcierre

La actividad minera se inicia con las actividades de prospección, las mismas que consisten en la identificación de la zona en donde se ubica el yacimiento minero a través de la ubicación de anomalías geológicas en la corteza terrestre, en donde posiblemente puedan existir yacimientos minerales. Son actividades de prospección, por ejemplo, la toma de fotos aéreas, la interpretación de datos satelitales la prospección geoquímica y geofísica, etc. ("Manual de Minería”, p. 29-30).

De acuerdo con lo señalado por el artículo $1^{\circ}$ de la LGM, las actividades de prospección consisten en la investigación conducente a determinar áreas de posible mineralización por medio de indicaciones químicas y físicas medidas con instrumentos y técnicas de precisión. 
En base a los resultados de las actividades de prospección se determina el área sobre la que se efectuarán las actividades de exploración minera, actividades cuya finalidad será la de comprobar la existencia de minerales, su calidad, ubicación y la viabilidad de su explotación. Sobre el particular, el artículo $8^{\circ}$ de la LGM define a la exploración como la actividad minera tendiente a demostrar las dimensiones, posición, características mineralógicas, reservas y valores de los yacimientos minerales.

Ahora bien, para poder desarrollar las actividades de exploración el inversionista debe contar previamente con una concesión minera. No es posible desarrollar legalmente exploración minera sin contar con este título habilitante. Al respecto, el artículo $7^{\circ}$ de la LGM señala que "las actividades de exploración, explotación, beneficio, labor general y transporte minero son ejecutadas por personas naturales y jurídicas nacionales o extranjeras, a través del sistema de concesiones”. Por su parte, el artículo $9^{\circ}$ de la LGM señala que:

La concesión minera otorga a su titular el derecho a la exploración y explotación de los recursos minerales concedidos, que se encuentren dentro de un sólido de profundidad indefinida, limitado por planos verticales correspondientes a los lados de un cuadrado, rectángulo o poligonal cerrada, cuyos vértices están referidos a coordenadas Universal Transversal Mercator (UTM).

Adicionalmente a la concesión, para poder desarrollar las actividades de exploración el titular minero debe contar con la autorización para el inicio de actividades de exploración que otorga el Estado, para lo cual se deberá contar previamente con la aprobación del instrumento ambiental exigido, entre otros requisitos ${ }^{1}$.

Durante la fase de exploración se realizan estudios destinados a determinar la existencia de mineral en la zona, así como la viabilidad técnica y económica de la explotación del yacimiento. Es a raíz de las actividades propias de la exploración que se determina la magnitud (reserva) y calidad (ley) del mineral que se encuentra en el yacimiento. Dependiendo de ello, se determinará la rentabilidad del proyecto y si se procederá a la explotación del mismo (PROESMIN, s.f., p. 34).

Las actividades de exploración consisten, entre otras, en actividades de perforación, muestreo, análisis del contenido y tipo de mineral, estudios topográficos,

\footnotetext{
${ }^{1}$ Ver al respecto el artículo $75^{\circ}$ del Reglamento de Procedimientos Mineros aprobado por Decreto Supremo $N^{\circ}$ 018-92-EM y modificado por Decreto Supremo Nº 020-2012-EM.
} 
geológicos, geoquímicos, interpretación de imágenes, ejecución de galerías, cruceros y chimeneas de exploración y de plantas piloto de tratamiento que permitirá determinar si el mineral es tratable y su recuperabilidad, etc. lo que a su vez supondrá la adquisición o alquiler de equipos y maquinaria, contratación de servicios, tanto de personal propio como de empresas especializadas, desembolsos para sufragar gastos de alojamiento, alimentación, transporte, etc. De igual modo durante la fase de exploración resultará necesario incurrir en gastos por concepto de asesorías y consultorías, montaje, instalación, mantenimiento de equipos, estudios socio ambientales y de protección ambiental, relaciones comunitarias, comunicaciones, seguridad y vigilancia, entre otros.

Cabe resaltar que mientras que los gastos de prospección se pueden dar en una etapa inicial sin necesidad de contar con títulos habilitantes, las actividades de exploración sólo podrán desarrollarse en la medida que el inversionista sea titular de una concesión minera y se haya obtenido la autorización estatal para el inicio de las actividades de exploración.

Ahora bien, como resultado de la actividad de exploración caben dos posibilidades: a) que el proyecto se declare inviable, o; b) que el proyecto sea viable. La viabilidad del proyecto se determina en función de un Estudio de Factibilidad, el mismo que tiene como objetivo analizar y demostrar la viabilidad técnica y comercial de la explotación. En el mismo se describen las reservas, leyes, método propuesto de explotación, plan de desarrollo, costos de transporte, etc. Es como consecuencia de este análisis que el inversionista minero da paso al inicio de la etapa de desarrollo o preparación, para lo cual se deberá obtener la autorización estatal correspondiente.

En la fase de desarrollo se implementarán y ejecutarán los trabajos de infraestructura necesarios para poder llevar a cabo la explotación y se realizarán las inversiones destinadas a hacer posible el acceso y la extracción del mineral, tales como remoción de tierra, excavación, construcción del campamento, de acceso al depósito, apertura de socavones, pozos, galerías, chimeneas, plantas de agua, caminos y vías de acceso, etc. (García Montufar, 1989, p. 14).

Luego de culminar con las etapas antes mencionadas y contar con la infraestructura necesaria para acceder al yacimiento y proceder a su explotación, recién se procederá a extraer el mineral dando inicio a la etapa de producción. Finalizada la etapa de producción la actividad minera concluirá con el cierre y post cierre de la mina. 
Ahora bien, el presente trabajo, pretende abordar el tratamiento de las inversiones que el titular de la actividad minera debe efectuar en la primera de las fases de la actividad minera: la fase de prospección y exploración. Esto es, nos referiremos a las inversiones efectuadas en una fase inicial de la actividad minera cuya finalidad es comprobar la existencia de minerales así como si su explotación resultaría o no viable desde un punto de vista técnico y económico.

En tal sentido, estas inversiones serán desembolsos importantes y de alto riesgo, pues nos encontramos en una fase en la que se apuesta por un proyecto sin certeza alguna respecto de una posible recuperabilidad de la inversión. En esta fase y debido a la ausencia de ingresos, los desembolsos efectuados van acumulándose generando pérdidas año a año. Nuestro trabajo revisará su tratamiento para efectos fiscales y la posibilidad de imputar tales desembolsos contra los ingresos que se generen en el futuro, o su recuperabilidad en caso el proyecto resulte trunco o inviable.

Considerando todo lo antes señalado, ensayaremos la siguiente noción de "gastos de prospección minera" y de "gastos de exploración minera":

- Gastos de prospección minera: desembolsos destinados a la identificación de la zona en donde se encuentra el yacimiento minero a través de la ubicación de anomalías geológicas en la corteza terrestre por medio de indicaciones químicas y físicas medidas con instrumentos y técnicas de precisión.

- Gastos de exploración minera: desembolsos destinados a la comprobación de existencia de yacimientos minerales, sus dimensiones, ubicación, características, reservas y valores, así como la viabilidad técnica y económica de su explotación.

Cabe señalar que analizaremos el tratamiento de los gastos de prospección y exploración efectuados únicamente en una etapa preoperativa, eso es, en el supuesto de que el titular de la actividad minera no tenga ninguna actividad de explotación ni en dicho proyecto ni en un proyecto o concesión distintos. Si bien es posible que un inversionista que tiene unidades productivas desarrolle a la par actividades de exploración en la misma unidad de producción o en una concesión distinta, el supuesto al que nos avocamos es el del inversionista que sólo desarrollo actividades en una etapa preoperativa. 


\section{CAPÍTULO II: MARCO NORMATIVO TRIBUTARIO APLICABLE}

El Impuesto a la Renta grava la renta neta, esto es la renta obtenida por los contribuyentes luego de deducidos los gastos destinados a producirla o mantenerla, incluyendo los desembolsos efectuados durante etapas pre-operativas que deberán reconocerse e imputarse contra la renta neta que el contribuyente llegue a generar en su etapa productiva. Sólo así, el Impuesto a la Renta gravará la real capacidad contributiva del sujeto.

A fin de determinar la renta neta de los contribuyentes, el artículo $37^{\circ}$ de la Ley del Impuesto a la Renta dispone que son deducibles de la renta bruta los gastos necesarios para la generación de renta gravada o el mantenimiento de la fuente productora de renta. Dicho artículo adicionalmente enumera una serie de egresos que son deducibles en forma limitada, condicionada o ilimitada, según las reglas específicas dispuestas para cada caso. Sin embargo, dicho listado es meramente enunciativo y no taxativo, en consecuencia, bastará acreditar la relación de causalidad para que sean considerados como gastos deducibles estén o no enumerados en el mencionado artículo $37^{\circ}$.

Ahora bien, el inciso o) del artículo $37^{\circ}$ de la Ley del Impuesto a la Renta, se refiere en forma específica a la deducción de gastos de exploración, preparación y desarrollo en que incurren los titulares de actividades mineras. Así, establece que estos gastos podrán ser deducidos en el ejercicio en que se incurran o deberán ser amortizados en los plazos y condiciones que señale la LGM y sus normas complementarias y reglamentarias. Por su parte, el artículo $74^{\circ}$ de la LGM, dispone lo siguiente:

El valor de adquisición de las concesiones, se amortizará a partir del ejercicio en que de acuerdo a ley corresponda cumplir con la obligación de producción mínima, en un plazo que el titular de actividad minera determinará en ese momento, en base a la vida probable del depósito, calculada tomando en cuenta las reservas probadas y probables y la producción mínima obligatoria de acuerdo a ley. El plazo así establecido deberá ser puesto en conocimiento de la Administración Tributaria al presentar la Declaración 
Jurada Anual del Impuesto a la Renta correspondiente al ejercicio en que se inicie la amortización, adjuntando el cálculo correspondiente.

El valor de adquisición de las concesiones incluirá el precio pagado, o los gastos de petitorio, según el caso.

Igualmente, incluirá lo invertido en prospección y exploración hasta la fecha en que de acuerdo a ley corresponda cumplir con la producción mínima, salvo que se opte por deducir lo gastado en prospección y/o exploración en el ejercicio en que se incurra en dichos gastos.

Cuando por cualquier razón la concesión minera fuere abandonada o declarada caduca antes de cumplir con la producción mínima obligatoria, su valor de adquisición se amortizará íntegramente en el ejercicio en que ello ocurra. En el caso de agotarse las reservas económicas explotables, hacerse suelta o declararse caduca la concesión antes de amortizase totalmente su valor de adquisición; podrá, a opción del contribuyente, amortizarse de inmediato el saldo, o continuar amortizándose anualmente hasta extinguir su costo dentro del plazo originalmente establecido.

De acuerdo a lo señalado por la norma antes citada, lo invertido en prospección y exploración hasta la fecha en que de acuerdo a la ley corresponda cumplir con la producción mínima, esto es, durante la etapa preoperativa, podrá amortizarse en un plazo que se determine en base a la vida probable del depósito, salvo que se opte por deducir lo gastado en el ejercicio en que se incurra en dichos gastos.

Como puede verse, el artículo $74^{\circ}$ de la LGM constituye la norma especial o específica que regula el tratamiento de los gastos de prospección y exploración minera que se efectúan antes del inicio de la etapa productiva, entendiendo por tal a la fecha en que se llegue a cumplir con la producción mínima legal establecida en la propia LGM. En tal sentido, lo dispuesto por el artículo $74^{\circ}$ de la LGM rige sobre cualquier otra disposición de carácter general en base al Principio "ley especial rige sobre ley general". El Tribunal Fiscal se ha pronunciado en este sentido al señalar en la Resolución del Tribunal Fiscal $N^{\circ}$ 5732-5-2003 respecto de la deducibilidad de las concesiones mineras lo siguiente:

(...) existe una ley específica (TUO de la Ley General de Minería) que regula aspectos vinculados a la deducibilidad de las concesiones mineras en el Impuesto a la Renta, por lo que en aplicación del principio de especialidad de las normas debe primar ésta sobre 
la ley general (Ley del Impuesto a la Renta) en tanto haya contradicción entre ambas (...).

Ahora bien, son varias las controversias interpretativas que han surgido a lo largo del tiempo en relación a la aplicación del artículo $74^{\circ}$ de la LGM, generando incertidumbre, falta de certeza y de seguridad jurídica en torno al tratamiento tributario otorgado a la deducción de los gastos de prospección y exploración.

En primer término, existen diversas interpretaciones en relación a lo que debe entenderse por "lo invertido en prospección y exploración”. Si bien la Ley del Impuesto a la Renta se refiere en su inciso o) al término "gastos", la redacción del artículo $74^{\circ}$ de la LGM pareciera referirse a inversiones en general, por lo que existen dudas sobre si esta regla se aplica también a la deducción de egresos que califiquen como costo, o en general inversiones que no califiquen en estricto como "gasto".

De otro lado, corresponde analizar si es que la norma sólo resulta aplicable a desembolsos que califican como "prospección” y "exploración” bajo los términos técnicos mineros, o si tal definición puede extenderse a otro tipo de desembolsos de tipo preoperativo. Resulta claro que este tratamiento no aplicará a los gastos de desarrollo, pero existen gastos de tipo administrativo que en estricto no califican como gastos de exploración desde un punto de vista técnico. Se tratan más bien de gastos que tendrían la naturaleza de gastos de organización o preoperativos, conceptos que estarían regulados por el inciso g) del artículo $37^{\circ}$ de la Ley del Impuesto a la Renta. Estos matices aún no resultan claros y no han recibido un tratamiento unánime por parte de los contribuyentes y de la Administración Tributaria. Se trata aún de temas controvertidos que no han sido zanjados.

Otro asunto controvertido en relación a la aplicación de la norma tributaria, está referido a lo que debe entenderse por "deducción del gasto en el ejercicio en que se incurra". Tenemos que por un lado se considera que el "incurrido" hace referencia al ejercicio de desembolso efectivo y constituye una excepción a la aplicación del Principio de Devengado. De otra parte, la Administración Tributaria ha efectuado acotaciones al considerar que el ejercicio en que se incurre en un gasto debe ser el ejercicio en que se inicia operaciones, esto considerando qué en aplicación del criterio de asociación de ingresos con gastos, los gastos deben deducirse en forma correlativa con el ejercicio en que se genere ingresos. Este criterio interpretativo ha sido aplicado para los gastos preoperativos regulados en el inciso g) del artículo $37^{\circ}$ de la Ley del 
Impuesto a la Renta; sin embargo, cabe analizar si estamos ante el mismo tipo de gastos y de tratamiento normativo o nos encontramos en un supuesto distinto.

Finalmente, en relación a la posibilidad de deducir los gastos vía amortización durante la vida probable del depósito, existen diversos criterios adoptados respecto a los plazos y métodos de amortización que recoge la norma tributaria, y cuya aplicación genera incertidumbre a los inversionistas.

Los temas antes mencionados revisten singular importancia para el análisis del inversionista al momento de planificar los proyectos mineros, de manera tal que bajo reglas claras y con garantías de seguridad jurídica suficiente se garantice el retorno de su inversión. Como vemos, las reglas no están lo suficientemente claras y existen diversos criterios de interpretación y dudas sobre el tratamiento tributario aplicable. Es así que en un escenario en que las inversiones mineras han empezado a reducirse, limitarse, condicionarse o existen mayores factores de riesgo, la certidumbre jurídica se convierte en un elemento de análisis esencial para la planificación y ejecución de futuras inversiones. 


\section{CAPÍTULO III: EL “GASTO DE PROSPECCIÓN Y EXPLORACIÓN MINERA” REGULADO POR LA NORMA TRIBUTARIA}

\subsection{Artículo $74^{\circ}$ de la Ley General de Minería: ¿gasto o inversión?}

El inciso o) del artículo $37^{\circ}$ de la Ley del Impuesto a la Renta regula la deducción de los "gastos" de exploración en que incurren los titulares de la actividad minera remitiéndose a lo dispuesto en forma específica por la LGM. Por su parte, el artículo $74^{\circ}$ de la LGM se refiere a la deducción de "lo invertido" en prospección y exploración. Esta aparente discrepancia en la terminología usada por ambas normas ("gasto" versus "lo invertido") ha generado dudas en relación a la aplicación y alcances del tratamiento tributario previsto en el artículo $74^{\circ}$ de la LGM.

Sobre el particular, se entiende por "gasto" a la disminución del beneficio económico durante un período contable en forma de disminución del valor de los activos o bien originados en una obligación o aumento de los pasivos, que dan como resultado disminuciones en el patrimonio neto, y no están relacionados con las distribuciones realizadas a los propietarios de ese patrimonio (Plan Contable General Empresarial, Resolución del Consejo Normativo de Contabilidad Nº43-2010-EF/94, 2010).

De otro lado, el término inversión se refiere a decir de Peumans (1967), a todo desembolso de recursos financieros para adquirir bienes concretos durables $o$ instrumentos de producción, denominados bienes de equipo, y que la empresa utilizará durante varios años para cumplir su objeto social (p. 21). Para Cholvis (1974), la inversión es la colocación de un capital en determinada empresa u operación. Agrega que en el campo de la contabilidad los rubros activos representan la inversión de los capitales propios y ajenos que se utilizan para el cumplimiento de los objetivos de la explotación (p.77).

Como puede verse el término "inversión" está relacionado con erogaciones que tendrán uso por varios años y que por tanto estarán asociados a ingresos que se generen por varios períodos en el futuro. Las inversiones son registradas contablemente como 
"activos", término definido como el "recurso controlado por la entidad como resultado de sucesos pasados, del que la empresa espera obtener beneficios económicos". (Plan Contable General Empresarial, Resolución del Consejo Normativo de Contabilidad $N^{\circ}$ 043-2010-EF/94, 2010).

Así tenemos que mientras que un "gasto" implica una disminución del beneficio económico en un período contable que afecta a los resultados o Estado de Ganancias y Pérdidas de dicho ejercicio, la "inversión" se registra como un activo que tendrá relación con beneficios económicos futuros a lo largo de uno o varios años.

La consecuencia de tal distinción es que mientras el "gasto" se deduce en un sólo ejercicio, la "inversión" se deduce en el ejercicio o ejercicios futuros en los que se espera obtener los beneficios económicos, esto es con la amortización o depreciación del activo a lo largo del tiempo, o con la realización o transferencia del activo en el ejercicio de su disposición.

Al respecto, el párrafo 4.45 del Marco Conceptual para la Información Financiera $^{2}$ (en adelante "Marco Conceptual), señala que un activo no es objeto de reconocimiento en el balance cuando se considera improbable que del desembolso se vayan a obtener beneficios económicos futuros. En lugar de ello, tal erogación -una que no genere beneficios en adelante-, se reconocerá como gasto en el estado de resultados. Asimismo, el párrafo 4.51 señala que para el reconocimiento de los gastos relacionados con el uso de activos se utilizan procedimientos sistemáticos y racionales de distribución a lo largo de varios períodos contables que se denominan depreciación o amortización.

De acuerdo a lo señalado, tenemos dos posibles interpretaciones del artículo $74^{\circ}$ de la LGM:

a) Entender que cuando la Ley del Impuesto a la Renta hace referencia a "gastos de exploración", se refiere exclusivamente a desembolsos que califican o se registran como "gasto" para efectos contables. Bajo este entendimiento el artículo $74^{\circ}$ de la LGM no sería aplicable a los desembolsos que califiquen como "activo", en cuyo caso se deducirían bajo las reglas generales del Impuesto a la Renta.

\footnotetext{
${ }^{2}$ Versión 2016, aprobada por Resolución de Consejo Normativo de Contabilidad N 063-2016-EF/30
} 
b) Entender que cuando el artículo $74^{\circ}$ de la LGM hace referencia a "lo invertido" en prospección y exploración, alcanza a todo tipo de inversiones, sea que califiquen o no desde un punto de vista contable como "gasto" o "activo".

\subsubsection{Aplicación de la norma tributaria sobre "activos"}

No existe duda respecto a que las erogaciones que se registran o califican contablemente como "gasto" se tratan de acuerdo a lo previsto en el artículo $74^{\circ}$ de la LGM. El cuestionamiento estaría referido entonces a si las disposiciones del artículo $74^{\circ}$ de la LGM resultarían aplicables también para aquellas erogaciones que se registren como "activos", que es como se registran -en términos generales- a las inversiones.

Dicho esto, y como cuestión previa debemos incidir en las características de los desembolsos destinados a la prospección y exploración minera en etapa preoperativa. Como hemos mencionado, se tratan de erogaciones que al darse en etapas previas a la producción no tienen correlación alguna con la generación de ingresos actuales, son por el contrario desembolsos que se efectúan con la expectativa de generar ingresos en el futuro en la medida que el proyecto resulte exitoso.

En este sentido, en términos generales los desembolsos en prospección y exploración en etapa preoperativa tienen para efectos contables la naturaleza de “activos”, pues estos tendrán relación con la generación de beneficios económicos futuros a lo largo de uno o varios años.

En línea con lo señalado, la Norma Internacional de Información Financiera 6: Exploración y Evaluación de Recursos Minerales, (2016) ${ }^{3}$-en adelante NIIF 6-, señala que la entidad debe establecer una política contable que especifique qué desembolsos se reconocerán como activos para exploración. Agrega que al establecer esta política se considerará el grado en que los desembolsos puedan estar asociados con el descubrimiento de recursos minerales específicos (párrafo 9) ${ }^{4}$.

\footnotetext{
${ }^{3}$ La NIIF 6 en su versión 2016 fue oficializada mediante Resolución del Consejo Normativo de Contabilidad $\mathrm{N}^{\circ}$ 063-2016-EF/30.

${ }^{4}$ Menciona como ejemplo a los siguientes desembolsos: adquisición de derechos de exploración; estudios topográficos, geológicos, geoquímicos y geofísicos; perforaciones exploratorias; excavaciones de zanjas y trincheras; toma de muestras; actividades relacionadas con la evaluación de la factibilidad técnica y la viabilidad comercial de la extracción de un recurso natural.
} 
Siendo ello así, carecería de sentido interpretar que el artículo $74^{\circ}$ de la LGM se limita a regular sólo aquellos desembolsos que se registran contablemente como "gasto", pues bajo este entendimiento la norma resultaría inaplicable ya que en términos generales, las erogaciones destinadas a la prospección y exploración minera se registran como "activos para exploración”.

Asimismo, entender que el artículo $74^{\circ}$ de la LGM se aplica sólo a aquellos desembolsos que se registran como "gasto", es decir, a aquellos desembolsos cuya naturaleza NO es la de generar beneficios futuros, terminaría por eliminar la finalidad para la cual la norma tributaria fue creada al regular el diferimiento y la amortización del gasto, esto es, que la deducción de las inversiones en exploración tengan un correlato con los ingresos que estas inversiones generen en el futuro.

Bajo dicha interpretación llegaríamos al absurdo de considerar que el tratamiento especial previsto en la LGM y que implica diferir el gasto y amortizarlo durante el período en que se generan ingresos, sería aplicable a gastos que no conllevaron su generación. Nos preguntamos entonces: ¿qué sentido tendría prever la deducción vía amortización tributaria para erogaciones que no tienen asociación con beneficios futuros a lo largo de los años?

Justamente lo que busca la norma tributaria es la deducción de los montos invertidos en exploración vía la amortización a lo largo de la vida de la mina de manera tal que estos desembolsos tengan un correlato con los ingresos que generen, esto porque las inversiones (reconocidas como activo) son las que tienen vinculación con los beneficios futuros generados por el descubrimiento del mineral. Resultaría ilógico pretender que sólo lo que califique para efectos contables como gasto (por no tener relación con la generación de los ingresos futuros), sea deducible tributariamente de las rentas futuras vía amortización.

Interpretar que las normas que regulan la deducción de gastos de prospección y exploración engloban también a los activos, resulta lógico y consistente con la finalidad para la cual la norma fue creada, y asimismo, con el tratamiento financiero aplicable a dichos desembolsos.

Así, corresponderá que los desembolsos en exploración que tengan vinculación con el descubrimiento de recursos y generación de beneficios futuros se reconozcan 
contablemente como activo para exploración y se amorticen tanto financiera como tributariamente.

Por el contrario, los desembolsos efectuados durante la etapa de exploración que no tengan vinculación con la generación de beneficios futuros se reconocerán como gasto del ejercicio para efectos contables (de acuerdo a la política establecida por el contribuyente), mientras que para efectos tributarios el inversionista podrá deducir dicho gasto en el ejercicio en que se incurra.

En tal sentido, consideramos que la finalidad del legislador al regular el tratamiento tributario de los gastos de prospección y exploración minera ha sido la de recoger la lógica de la norma contable, y que supone regular la deducción de partidas que califican como activos.

De otro lado, y más allá de la finalidad de la norma, consideramos que a fin de entender sus alcances corresponde su análisis bajo distintos métodos de interpretación admitidos por el Derecho.

Al respecto, el inciso o) del artículo $37^{\circ}$ de la Ley del Impuesto a la Renta hace referencia a "gastos de exploración" mientras que el artículo $74^{\circ}$ de la LGM se refiere a "lo invertido en prospección y exploración".

De una interpretación literal de lo dispuesto por el artículo $74^{\circ}$ de la LGM tenemos que el uso del término "lo invertido", permite concluir que las regulaciones previstas en dicho artículo alcanza a las partidas que califican como "activos" en tanto que así es como se registran las inversiones o desembolsos que tienen relación con la generación de beneficios futuros.

Asimismo, de una interpretación sistemática o conjunta de ambos dispositivos, se concluye que el supuesto regulado por la norma tributaria no podría limitarse a lo que califique en estricto como "gasto", sino que alcanza también y en forma general a lo que se invierta en prospección y exploración minera, abarcando tanto a lo que califique en forma estricta como "gasto", como a cualquier otra "inversión", sea que esta sea registrada como un activo o no.

Bajo esta interpretación, el término "gasto" contenido en la Ley del Impuesto a la Renta no puede analizarse en forma restrictiva y aislada. El entendimiento de la misma debe complementarse con lo dispuesto por la LGM, norma que además alcanza 
no sólo a las inversiones en exploración, sino también a las inversiones en prospección minera.

De otro lado, y aun en el supuesto que se considere que la Ley del Impuesto a la Renta sólo hace referencia a lo que en estricto califica contablemente como "gasto", debemos señalar que teniendo la LGM igual jerarquía normativa, sus reglas son aplicables de igual manera a los activos o inversiones pues dicha norma regula "lo invertido" en prospección y exploración.

En conclusión, consideramos que no cabe limitar el tratamiento de los gastos de prospección y exploración sólo a aquellos desembolsos que califiquen contablemente como "gasto", sino que dicho tratamiento resulta aplicable también a las inversiones que se registran como "activo".

En esta misma línea, si revisamos comparativamente nuestra legislación podemos encontrar que el artículo $53^{\circ}$ de la Ley Orgánica de Hidrocarburos (Ley 26221, 1993) regula la deducción de los desembolsos que se efectúan en la etapa preoperativa utilizando el siguiente texto: "los gastos de exploración y desarrollo así como las inversiones que realicen los Contratistas hasta la fecha en que se inicie la extracción comercial de Hidrocarburos (...)”.

Como vemos, en el sector hidrocarburos tenemos una sola norma que hace referencia tanto a "gastos" como a "inversiones", mientras que para el sector minero tenemos dos normas: una recogida en la Ley del Impuesto a la Renta que se refiere a "gastos", y otra en la LGM que se refiera a "lo invertido". Pues bien, si no existe duda que el artículo $53^{\circ}$ de la Ley Orgánica de Hidrocarburos incluye tanto a "gastos" como a "activos" nos preguntamos: ¿por qué habría que tener una interpretación distinta de la norma tributaria minera?. Entendemos que ambas normas, tanto la aplicable al sector hidrocarburos como al sector minero, al referirse a "inversiones" o "lo invertido", incluyen a conceptos que califican contablemente como "activo".

\subsubsection{Aplicación de la norma tributaria sobre "activos fijos"}

Quizá la mayor duda en relación al alcance de las normas que regulan los desembolsos en prospección y exploración, se genere en relación a aquellas erogaciones que bajo un concepto general podrían calificar como "activo fijo" (aunque no necesariamente se registren como tal). 
Como sabemos no existe una definición de "activo fijo" en la Ley del Impuesto a la Renta ni su reglamento, sin embargo, tal y como lo ha señalado el Informe $\mathrm{N}^{\circ} 035$ 2007-SUNAT-2B0000 (2007), para entender dicho concepto resultan de aplicación las Normas Internacionales de Contabilidad, los Principios de Contabilidad Generalmente Aceptados (PCGA) y la Doctrina Contable. Al respecto, el Informe antes citado señala que de acuerdo con los PCGA, los activos fijos también conocidos como propiedad, planta y equipo o activos de planta, se utilizan para la producción y distribución de los productos y servicios, citando como ejemplos el terreno, los bienes inmuebles, el mobiliario, los accesorios e instalaciones, la maquinaria, el equipo y los vehículos. Asimismo, la Norma Internacional de Contabilidad 16 (NIC 16): Propiedades, Planta y Equipo $(2016)^{5}$-en adelante "NIC 16"-, señala que las propiedades, planta y equipo son los activos tangibles que: (a) posee una entidad para su uso en la producción o suministro de bienes y servicios, para arrendarlos a terceros o para propósitos administrativos; y, (b) se espera usar durante más de un periodo (párrafo 6). Por su parte, citando a Kohler, la Administración Tributaria define al "activo fijo" como el activo tangible que se tiene por los servicios que presta en la producción de bienes y servicios cualquier elemento de una planta ${ }^{6}$.

Por lo señalado podemos concluir que los activos fijos vienen a ser los activos tangibles utilizados para la producción y distribución de los productos y servicios que se esperan usar durante más de un período. Calificarían entonces bajo esta definición inversiones en exploración tales como vehículos, maquinarias, equipos para perforación, galerías de exploración, campamento de exploración, entre otros desembolsos propios de esta etapa.

La disyuntiva está entonces en definir si las inversiones en exploración que a su vez califican bajo el concepto de "activo fijo", deben depreciarse en función a su uso y por tanto se deducirse conforme a lo previsto por el artículo $38^{\circ}$ de la Ley del Impuesto a la $\operatorname{Renta}^{7}$; o si por el contrario, deben deducirse de conformidad con lo dispuesto por el artículo $74^{\circ}$ de la LGM.

\footnotetext{
${ }^{5}$ Versión 2016, aprobada por Resolución de Consejo Normativo de Contabilidad N $063-2016-E F / 30$

${ }^{6}$ Este concepto ha sido recogido también por el Tribunal Fiscal en las resoluciones $\mathrm{N}^{\circ} \mathrm{s} 3942-5-2010$ y 3461-3-2009.

${ }^{7}$ De acuerdo a lo establecido por el artículo $38^{\circ}$ de la Ley del Impuesto a la Renta, el desgaste o agotamiento que sufran los bienes del activo fijo que los contribuyentes utilicen en negocios, industria, profesión u otras actividades productoras de rentas gravadas de tercera categoría, se compensará
} 
Al respecto, bajo el entendimiento del artículo $74^{\circ}$ de la LGM que venimos planteando, la norma alcanzaría también a los activos, sin diferenciar entre "activos fijos" y otros tipos de activo. En tal sentido, correspondería que tales desembolsos formen parte del "activo de exploración", y se amorticen tributariamente a lo largo de la vida útil de la mina ${ }^{8}$.

Este es también el entendimiento que se tiene en el sector hidrocarburos al interpretar el artículo $53^{\circ}$ de la Ley Orgánica de Hidrocarburos (Ley 26221, 1993) antes mencionado. El término "inversión” recogido en este artículo incluye también a bienes que calificarían como "activo fijo", siendo claro para el sector hidrocarburos que no cabe la deducción vía depreciación de activos en una etapa preoperativa, pues estos forman parte del activo de exploración amortizable. Siguiendo la misma lógica, si el término "inversión" recogido en el artículo $53^{\circ}$ de la Ley Orgánica de Hidrocarburos incluye al "activo fijo", podemos concluir que el término "lo invertido" recogido en el artículo $74^{\circ}$ de la LGM también lo incluye.

De otro lado, hemos señalado que el artículo $74^{\circ}$ de la LGM constituye la norma tributaria especial o específica que rige el tratamiento fiscal de las inversiones en prospección y exploración, y por tanto en virtud del Principio de Especialidad de las normas jurídicas según el cual la norma especial prevalece sobre la norma de carácter general, la regulación contenida en la LGM rige sobre lo previsto por otras normas e incluso sobre el régimen general establecido en la Ley del Impuesto a la Renta. Entonces cabe preguntarnos, ¿el tratamiento recogido en el artículo $74^{\circ}$ de la LGM rige por especialidad sobre lo establecido por la Ley del Impuesto a la Renta en relación a la depreciación del activo fijo regulado en el artículo $38^{\circ}$ y siguientes de dicha norma?.

Debemos señalar también que la LGM no ha previsto una norma expresa que regule el tratamiento tributario de los activos fijos o los bienes sujetos a depreciación

mediante la deducción por las depreciaciones admitidas en la ley. Cabe señalar que el artículo $84^{\circ}$ de la LGM ha previsto para los contratos de estabilidad tributaria vigentes por quince años, la facultad de ampliar la tasa anual de depreciación de las maquinarias, equipos industriales y demás activos hasta el $20 \%$ anual de acuerdo a las características propias de cada proyecto, a excepción de las edificaciones y construcciones cuyo límite máximo es del 5\%; no obstante, bajo la legislación actual dichas tasas coincidirían con las previstas en el régimen general del Impuesto a la Renta.

${ }^{8}$ Considerando que nuestro análisis se centra en el caso de una empresa minera netamente preoperativa, no consideramos viable que el contribuyente opte por la deducción de desembolsos (aún menos activos fijos) en el ejercicio de lo incurrido, pues ello determinaría la generación de pérdidas tributarias que no podrían arrastre en su totalidad a futuro. 
utilizados en la etapa preoperativa, por lo que no existe norma que excluya a los “activos fijos" del ámbito de aplicación del artículo 74 de la LGM.

Pues bien, bajo este análisis jurídico, las inversiones en prospección y exploración que a su vez califican bajo el concepto general de "activo fijo", serían deducibles conforme a lo dispuesto por el artículo $74^{\circ}$ de la LGM en tanto dicha norma englobaría a todo tipo de activos.

No obstante y a fin de contrastar tal conclusión y analizar su razonabilidad, cabe hacer un análisis del tratamiento financiero aplicable a las inversiones en exploración que a su vez reúnen las características para ser calificadas conceptualmente como un "activo fijo":

- Conforme a lo previsto por la NIIF 6, los desembolsos efectuados en relación con la exploración y evaluación de recursos minerales a partir de la fecha en que se obtenga el derecho legal para explorar y hasta antes de que se pueda demostrar la factibilidad técnica y la viabilidad comercial de la extracción de recursos minerales se rigen por esta norma, y por tanto, de acuerdo a la política contable que adopte la empresa, incluso los bienes tangibles que se adquieran para ser usados durante más de un período, se registrarán como "activos para exploración".

- La NIC 16 establece (literal c) del numeral 3), que sus disposiciones NO resultan aplicables al reconocimiento y medición de activos para exploración y evaluación que se rigen por la NIIF 6. En tal sentido, a los "activos para exploración" no les resultará aplicable la NIC 16 y por tanto, el registro de una depreciación financiera. ${ }^{9}$

- No obstante, la misma NIC 16 señala que esta norma sí resultará aplicable a los elementos de propiedades, planta y equipo utilizados para desarrollar o mantener los "activos para exploración".

- Tenemos entonces que aquellos bienes tangibles de propiedad, planta y equipo adquiridos durante la etapa preoperativa para ser usados por más de un período, que NO califiquen como "activos para la exploración", o sirvan para desarrollarlos o mantenerlos, calificarán como "activo fijo", resultando

\footnotetext{
${ }^{9}$ Sobre el particular, el numeral 16 de la NIIF 6 señala que algunos activos para exploración y evaluación se tratan como tangibles, poniendo como ejemplo a los vehículos y equipos de perforación.
} 
aplicables las normas de la NIC 16, y por tanto el registro contable de su depreciación.

- Estos bienes a los que se refiere la NIC 16, que siendo adquiridos en una etapa exploratoria sí califican como "activo fijo", son denominados por la doctrina como "service assets" (activos de soporte) y tienen como característica el no tener una vida útil asociada a la vida de la mina (Rosado Silva, 2003, p. 124$125)^{10}$.

- En resumen, tenemos que para efectos financieros, los bienes tangibles adquiridos durante la etapa de exploración para ser usados por más de un período:

(i) Se registrarán como "activo para la exploración" en la medida que se traten de inversiones relacionadas con la exploración y evaluación de recursos minerales (búsqueda de recursos y viabilidad de su explotación), y se reconozcan como tal en aplicación de la NIIF 6. A estos activos nos les resulta de aplicación la NIC 16, y por tanto, no están sujetos al registro de una depreciación financiera.

(ii) Se registrarán como "activo fijo" en la medida que se traten de propiedad, planta y equipo utilizados para desarrollar o mantener los activos para exploración. Estos "activos de soporte" se caracterizan por no tener una vida útil asociada a la vida del depósito minero, se regirán por la NIC 6 y estarán sujetos a una depreciación financiera.

De acuerdo a lo expuesto, resulta claro que a los "activos para la exploración" no les son aplicables las reglas contenidas en la NIC 16 y por tanto no se reconocerá su

${ }^{10}$ La anterior versión de la NIC 16 (aprobada por Resolución de Consejo Normativo de Contabilidad $\mathrm{N}^{\circ}$ 007-96-EF/93.01), tenía una redacción más clara que la actual, al señalar que la misma aplicaba a los inmuebles, maquinaria y equipos usados para desarrollar o mantener las actividades de exploración y extracción de minerales, petróleo, gas natural y los recursos no renovables similares, cuando son separables de esas actividades o activos.

Tanto la norma vigente como la anterior, buscan incluir en la aplicación de la NIC 16 a los "activos de soporte". Mientras que la norma vigente identifica a estos activos como aquellos necesarios para desarrollar o mantener los activos para exploración, la norma anterior los identificaba como aquellos necesarios para desarrollar o mantener las actividades de exploración en la medida que sean separables.

Sobre este particular, Chumacero Quispe (2015), ha señalado que si un activo fijo está relacionado a la exploración y evaluación de recursos minerales, no se encontrará bajo el alcance de la NIC 16 por exclusión expresa del párrafo tercero. En tal sentido, opina que en tanto dicho activo pueda ser separado y trasladado a otro proyecto distinto a la actividad minera sí estaría dentro del alcance de la NIC 16 (p. 8687).

En este mismo sentido, la Resolución del Tribunal Fiscal Nº 031-1-2013 ha señalado que a los inmuebles, maquinarias y equipos no separables de los activos o actividades excluidos del alcance de la NIC 16, tampoco les será aplicable dicha norma contable. 
depreciación financiera. Siendo ello así, no cabría tampoco la aplicación de las normas tributarias que regulan la deducción de la depreciación del activo fijo conforme lo establece el artículo $38^{\circ}$ de la Ley del Impuesto a la Renta.

En efecto, por un lado, el artículo $38^{\circ}$ de la Ley del Impuesto a la Renta resulta aplicable a los "activos fijos", pero no así a los "activos para exploración". De otro lado, no cabe la aplicación de normas que regulan la depreciación tributaria, cuando en aplicación de las normas contables no corresponde registrar depreciación financiera alguna, más aún cuando la norma tributaria condiciona la deducción de la depreciación a su contabilización. ${ }^{11}$

En ese sentido, consideramos que a los activos tangibles que se esperan usar durante más de un período y que se registran como "activos para exploración" les es aplicable el tratamiento tributario previsto en el artículo $74^{\circ}$ de la LGM, y que por el contrario, no se regulan por lo dispuesto en el artículo $38^{\circ}$ de la Ley del Impuesto a la Renta.

La duda surge en relación al tratamiento tributario aplicable a los "activos de soporte" que son registrados como "activo fijo" en aplicación de la NIC 16. Al respecto, si bien hemos sostenido que el artículo $74^{\circ}$ de la LGM es aplicable a los "activos", y que no existe una norma que excluya a los "activos fijos" de su ámbito, es también cierto que en este caso es posible sostener que el artículo $38^{\circ}$ de la Ley del Impuesto a la Renta resulta aplicable, y por tanto, estos activos no estarían sujetos a la amortización por el plazo de la vida del depósito minero a partir del inicio de la extracción comercial, sino a la depreciación en función de los porcentajes máximos establecidos en la Ley del Impuesto a la Renta y sus normas reglamentarias a partir de su uso.

Suma a esta posición, que de acuerdo a lo que hemos señalado, estos "activos de soporte" se caracterizan por no tener una vida útil asociada a la mina, y por tanto, su deducción durante el plazo de la vida del depósito minero no estaría permitiendo una adecuada asociación de los gastos con los ingresos que estos activos generan.

Tomemos como ejemplo el caso de una computadora adquirida en etapa de exploración. Financieramente este activo no calificaría como un "activo de

\footnotetext{
${ }^{11}$ De acuerdo a lo dispuesto por el inciso b) del artículo $22^{\circ}$ del Reglamento de la Ley del Impuesto a la Renta y respecto de los bienes del activo fijo distintos a edificaciones y construcciones dispone: "la depreciación aceptada tributariamente será aquella que se encuentre contabilizada dentro del ejercicio gravable en los libros y registros contables (...)".
} 
exploración" porque no se trataría de un bien utilizado o relacionado con la búsqueda de recursos minerales, y asimismo, porque aún en dicho caso este sería un "activo de soporte" utilizado para desarrollar o mantener los activos de exploración. Para efectos contables sería registrado entonces como un "activo fijo" contabilizándose su depreciación por el plazo de su vida útil (en promedio 3 años). Para efectos tributarios, si aplicamos el tratamiento previsto en el artículo $74^{\circ}$ de la LGM, dicha inversión se amortizaría en el plazo de la vida de la mina (en promedio 15 años ${ }^{12}$ ), y si aplicamos el artículo $38^{\circ}$ de la Ley del Impuesto a la Renta, la depreciación de deduciría con un tope máximo de $25 \%$ anual (4 años).

En términos generales y de acuerdo a lo expuesto, consideramos que la norma no otorga certeza sobre el tratamiento tributario aplicable pudiendo generar controversias interpretativas y acotaciones del fisco en ambos sentidos. Así caben las siguientes posibilidades:

- Que se desconozca la amortización tributaria aplicada de acuerdo al artículo $74^{\circ}$ de la LGM, de aquellos bienes que califiquen conceptualmente como "activo fijo", al considerar que correspondía su deducción vía depreciación conforme a las normas generales del Impuesto a la Renta. Como consecuencia de ello, además se desconoce la deducción de la depreciación al no haber sido registrada contablemente ${ }^{13}$, o por el contrario;

- Que se desconozca la deducción de la depreciación de bienes registrados como "activo fijo" al considerar que en aplicación del artículo $74^{\circ}$ de la LGM, correspondía diferir el gasto hasta el inicio de la extracción comercial y amortizarse por el plazo de la vida del depósito.

A fin de ejemplificar lo antes señalado, planteamos los siguientes casos:

\footnotetext{
12 Tomamos el lapso de 15 años como un promedio razonable para la vida probable de un depósito minero. A tal efecto podemos remitirnos a las Notas a los Estados Financieros de Compañía Minera Milpo S.A.A. al 31 de diciembre de 2016, que considera una vida útil para sus principales proyectos de 10 años (Atacocha), 14 años (Magistral) y 19 años (Pukaqaqa) (p. 36). Asimismo, podemos verificar que según los Estados Financieros de Compañía de Minas Buenaventura S.A.A por los años 2016, 2015 y 2014, la vida útil promedio de sus minas es de 13 años (p. 33).

${ }^{13}$ Como viene sucediendo hoy en relación a los costos de desarrollo minero. En efecto mientras los contribuyentes deducen lo invertido en función de lo dispuesto por el artículo $75^{\circ}$ de la LGM (amortización de uno a tres años); la Administración Tributaria califica dichas inversiones como activo fijo, desconoce la amortización y señala que deben depreciarse en función a los porcentajes de depreciación admitidos por ley.
} 
(a)Contribuyente que adquiere maquinaria y equipo, la registra como activo de exploración y la amortiza en los quince años de la vida de la mina. El contribuyente considera este tratamiento razonable pues permite un correlato entre el gasto y las rentas que se genere al iniciar la explotación. Por el contrario, optar por la depreciación del activo fijo supondría enviar a resultados el monto de la depreciación que no podrá deducir de renta alguna generando así pérdida tributaria. En tanto los períodos de exploración son bastante largos, ello podría conllevar la imposibilidad de imputar la pérdida tributaria contra las futuras rentas netas teniendo en cuenta las reglas para el arrastre de pérdidas vigentes $^{14}$.

En este caso, la Administración Tributaria podría cuestionar el proceder del contribuyente y desconocer la amortización señalando que la maquinaria y equipo debía deducirse bajo las reglas de depreciación del activo fijo. Asimismo, y en la medida que la depreciación no fue contabilizada (por no haberse registrado ni el activo fijo ni su depreciación contable), no admite tampoco su deducción como tal ${ }^{15}$.

(b)Contribuyente que adquiere maquinaria y equipo y la registra como activo fijo depreciable a una razón del $20 \%$ (en cinco períodos) ${ }^{16}$. El contribuyente considera razonable este proceder pues le permite recuperar fiscalmente el monto invertido en un plazo bastante corto.

En este caso, la Administración Tributaria podría cuestionar el proceder del contribuyente al considerar que la maquinaria y equipo debió formar parte del

\footnotetext{
${ }^{14}$ De acuerdo a lo previsto por el artículo $50^{\circ}$ de la Ley del Impuesto a la Renta, los contribuyentes podrán compensar la pérdida neta de tercera categoría con arreglo a uno de los siguientes sistemas: (a) compensar la pérdida imputándola a las rentas netas que obtengan en los cuatro ejercicios inmediatos posteriores al de su generación; y, (b) compensar la pérdida imputándola al 50\% de las rentas que se obtengan en los ejercicios inmediatos posteriores.

${ }^{15}$ Cabe mencionar que en la Resolución No 10379-4-2013, el Tribunal Fiscal señaló que el régimen de depreciación previsto en el artículo $84^{\circ}$ de la LGM constituye un régimen distinto al establecido en la normativa del Impuesto a la Renta, no resultando exigible el requisito de contabilización para acceder a la depreciación del 20\%. No obstante, en el caso en mención la Administración reparó la depreciación deducida en exceso a la ya contabilizada. No se refiere al supuesto en que no haya registro del activo fijo ni se haya contabilizado depreciación alguna.

${ }^{16}$ Según lo señalado por la Tabla de depreciación máxima contenida en el literal b) del artículo 22 del Reglamento de la Ley del Impuesto a la renta, la maquinaria y equipo utilizado por la actividad minera se deprecia a un porcentaje anual máximo de $20 \%$.
} 
activo de exploración y amortizarse en 15 años, desconoce la depreciación generando la disminución del saldo a favor.

(c)Contribuyente que edifica o construye inmuebles (campamento de exploración, sistema de agua, planta piloto, etc.), considerando la inversión como activo de exploración amortizable en el plazo de quince años de vida de la mina. El contribuyente considera razonable este proceder pues le permite recuperar fiscalmente el monto invertido en el plazo de explotación.

En este caso, la Administración Tributaria podría cuestionar el proceder del contribuyente al considerar que los bienes debieron registrarse como edificación y construcción y depreciarse a una razón del 5\% anual (en un lapso de 20 años $)^{17}$ contados a partir de su uso. Ello significaría que la deducción de depreciación durante el período exploratorio, generando pérdidas que no necesariamente podrían recuperarse.

(d)Contribuyente que edifica o construye inmuebles (campamento de exploración, sistema de agua, planta piloto, etc.), considerando la inversión como edificación y construcción depreciable a una razón del 5\% anual en un lapso de 20 años.

En este caso, la Administración Tributaria no efectuaría acotaciones ya que la opción de la amortización sería más favorable al contribuyente, pero el inversionista se encontrará en una situación fiscal desventajosa en tanto podrá deducir la depreciación de las rentas que se generen hasta el año quince; sin embargo, no podrá imputar el saldo no depreciado contra renta alguna generando pérdidas no recuperables (salvo que se generen otros proyectos).

Como puede verse, la norma tributaria tal y como está redactada no permite determinar un tratamiento claro en relación a los bienes que tienen características de activo fijo y que se adquieren durante la exploración minera. Por el contrario, la regulación vigente resulta insuficiente y poco clara, llevando a situaciones no previstas y que no se condicen con la finalidad de diferir los montos invertidos en exploración y asociar dichos desembolsos con la generación de las rentas que se generen a lo largo de la vida del depósito minero. Asimismo, la norma tributaria tampoco limita o prevé en forma expresa un tratamiento distinto para los casos en que un activo no responda o no tenga relación con la vida útil de la mina por consumirse o desgastarse en plazos

\footnotetext{
${ }^{17}$ Según lo dispuesto por el artículo $39^{\circ}$ de la Ley del Impuesto a la Renta.
} 
significativamente menores, como es el caso de algunos activos fijos con una vida útil corta.

\subsubsection{Corolario}

Teniendo en consideración todo lo antes señalado, en aras de la seguridad jurídica consideramos recomendable proponer una precisión normativa que permita zanjar cualquier duda o cuestionamiento al tratamiento tributario que los titulares de la actividad minera otorgan a este las inversiones en prospección y exploración.

En tal sentido, consideramos recomendable que la norma tributaria que regula el tratamiento de este tipo de erogaciones haga referencia en general a "los desembolsos" que realicen los titulares de la actividad minera, evitando la distinción entre "gasto", “activo" o "inversión", término utilizado también por la NIIF 6.

Asimismo, resulta recomendable que la norma establezca en forma expresa el tratamiento tributario aplicable a las erogaciones que bajo un concepto general califican como "activo fijo", a fin de determinar si el mismo se rige por el artículo $74^{\circ}$ de la LGM o bajo las reglas de depreciación previstas por la Ley del Impuesto a la Renta, previendo asimismo un tratamiento específico para aquellos "activos fijos" que con registrados como tal por calificar como "activos de soporte" y cuya vida útil no tiene relación con la vida del depósito minero.

\subsection{Alcance del concepto de "prospección y exploración" y sus diferencias con otro tipo de gastos pre operativos}

El inciso o) del artículo $37^{\circ}$ de la Ley del Impuesto a la Renta se refiere a la deducción de los gastos de exploración. Por su parte, el artículo $74^{\circ}$ de la LGM se refiere a la deducción de los gastos de prospección y exploración. Corresponde entonces analizar el concepto de gasto de "prospección" y el de "exploración" a fin de entender los alcances de las normas antes citadas.

Conforme hemos desarrollado en el Capítulo I, entendemos por gastos de prospección y exploración minera a los siguientes:

- Son gastos de prospección minera, aquellos desembolsos destinados a la identificación de la zona en donde se encuentra el yacimiento minero a través 
de la ubicación de anomalías geológicas en la corteza terrestre por medio de indicaciones químicas y físicas medidas con instrumentos y técnicas de precisión.

- Son gastos de exploración minera, aquellos desembolsos destinados a la comprobación de existencia de yacimientos minerales, sus dimensiones, ubicación, características, reservas y valores, así como la viabilidad técnica y económica de su explotación.

Asimismo, entendemos por gastos de prospección y exploración minera efectuados antes del inicio de la etapa productiva, a aquellos desembolsos ejecutados antes del inicio de la actividad de explotación de mineral, sea que esta actividad se desarrolle en el mismo proyecto o concesión o en uno distinto.

Como vemos, es la naturaleza y el destino de los desembolsos de acuerdo a criterios técnicos y especializados lo que determina su calificación como gastos de prospección y exploración. Su identificación por tanto dependerá de los fines para los que se destinen desde un punto de vista técnico.

Pues bien, además de los gastos de prospección y exploración en una fase previa al inicio de la etapa productiva será necesario realizar una serie de desembolsos distintos a los que califican propiamente como prospección y exploración. En efecto, habrán desembolsos que corresponderán a la definición de gastos de desarrollo pues su finalidad no será la de ubicar el mineral, sino la de acceder a él. Asimismo, habrán desembolsos que no correspondan a los de prospección y exploración pues su finalidad será distinta a la de encontrar el mineral y determinar la viabilidad de su explotación, tal es el caso por ejemplo de algunos gastos de tipo administrativo, que no encajarían en la definición de gastos de prospección y exploración bajo un punto de vista técnico.

La distinción entre un tipo de gastos y otro resulta fundamental para determinar el tratamiento tributario aplicable, pues mientras la deducción de los gastos de prospección y exploración se regirá por la regla específica dispuesta en el artículo $74^{\circ}$ de la LGM, la deducción de los gastos que no califiquen como tales se regirán por lo dispuesto en las normas generales de la Ley del Impuesto a la Renta u otras normas especificas.

Teniendo en consideración lo señalado, además de los gastos de prospección y exploración minera consideramos que los desembolsos que se efectúan antes del inicio 
de la etapa de operaciones podrían calificar en uno de los siguientes conceptos: (i) gastos preoperativos generales; (ii) gastos de desarrollo; y, (iii) gastos de cateo. A continuación pasamos a desarrollar sus características, las diferencias existentes entre los mismos y los gastos de prospección y desarrollo, así como en el tratamiento tributario que le corresponde a cada uno de ellos.

\subsubsection{Gastos preoperativos generales}

Como hemos mencionado, no todos los gastos efectuados en una etapa anterior a las operaciones mineras califican como gastos de prospección y exploración. En efecto, sólo calificarán como tales aquellos que desde un punto de vista técnico tengan dicha naturaleza y estén destinados a la ubicación del yacimiento minero, la comprobación de sus características y la viabilidad de su explotación. Existirán por tanto gastos que no encajen en esta definición técnica ni tampoco califiquen como gastos de desarrollo o preparación, a estos otros gastos los denominaremos "gastos preoperativos generales".

Los "gastos preoperativos generales" tienen una índole distinta a los gastos de prospección, exploración y de desarrollo. Se tratan de desembolsos de corte administrativo, vinculados por ejemplo a la constitución y organización de la sociedad, gastos de financiamiento, alquiler de oficinas, entre otros.

Al respecto en el Informe $\mathrm{N}^{\circ}$ 079-2016-SUNAT/5D0000, la Administración Tributaria ha definido como gastos preoperativos a "los gastos de establecimiento, de puesta en marcha de operaciones, de inicio de actividades o los desembolsos necesarios para abrir una nueva instalación o para comenzar una operación o el lanzamiento de nuevos productos o procesos". En dicho Informe al definir los gastos preoperativos la Administración Tributaria se remite a la descripción de gastos de establecimiento recogida en la NIC 38 - Intangibles, señalando que pueden consistir en costos de inicio de actividades tales como costos legales y administrativos soportados en la creación de una entidad con personalidad jurídica, desembolsos necesarios para abrir una nueva instalación, una actividad o para comenzar una operación (costos de preapertura) o bien costos de lanzamiento de nuevos productos o procesos (costos previos a la operación) (p.3).

Este tipo de gastos se rigen por el régimen común del Impuesto a la Renta previsto en el inciso g) del artículo $37^{\circ}$ de la Ley del Impuesto a la Renta y el literal d) 
del Reglamento de la Ley del Impuesto a la Renta (Decreto Supremo $N^{\circ}$ 122-94-EF y normas modificatorias, 1994), que a la letra señalan lo siguiente:

Artículo $37^{\circ}$

g) Los gastos de organización, los gastos preoperativos iniciales, los gastos preoperativos originados por la expansión de actividades de la empresa y los intereses devengados durante el período preoperativo, a opción del contribuyente, podrán deducirse en el primer ejercicio o amortizarse proporcionalmente en el plazo máximo de $\operatorname{diez}(10)$ años.

Artículo $21^{\circ}$

d) La amortización a que se refiere el inciso g) del Artículo $37^{\circ}$ de la Ley, se efectuará a partir del ejercicio en que se inicie la producción o explotación.

Una vez fijado el plazo de amortización sólo podrá ser variado previa autorización de la SUNAT. El nuevo plazo se computará a partir del ejercicio gravable siguiente a aquél en que fuera presentada la solicitud por el contribuyente, sin exceder en total el plazo máximo de diez años.

Los intereses devengados durante el período preoperativo comprenden tanto a los del período inicial como a los del período de expansión de las operaciones de la empresa.

En relación a la interpretación de dichas normas, en el Informe $\mathrm{N}^{\circ}$ 62-2009SUNAT/2B0000 del 24 de abril de 2009, la Administración Tributaria señaló que la opción de deducir en el primer ejercicio los gastos de organización y preoperativos debe entenderse referida a la deducción en el ejercicio gravable en que se inicia la producción o explotación, esto es, que la referencia al término "primer ejercicio" únicamente cobra sentido si se quiere diferir la deducción del gasto al primer ejercicio de terminada la etapa pre operativa. Esta posición ha sido ratificada por el Tribunal Fiscal en diversas Resoluciones, entre las cuales que podemos citar la $\mathrm{N}^{\circ}$ 5349-3-2005 y la No 2989-4-2010, entre otras.

De acuerdo a lo señalado por las normas antes citadas y los criterios interpretativos asumidos por la Administración Tributaria y el Tribunal Fiscal, tenemos que los gastos preoperativos regulados por el régimen común del Impuesto a la Renta pueden deducirse a opción del contribuyente: (i) en el primer ejercicio en que se inicie la producción; o, (ii) amortizarse en forma proporcional a partir del inicio de la producción en un plazo que no podrá superar los diez años. 
Como puede verse, el tratamiento tributario que corresponde a los "gastos preoperativos iniciales" difiere del previsto en el artículo $74^{\circ}$ de la LGM en lo siguiente:

Tabla 3.1.

Diferencias entre el tratamiento tributario de los gastos de prospección y exploración y los gastos preoperativos generales

\section{Prospección y Exploración}

- A opción del contribuyente, el gasto puede deducirse en el ejercicio en que se incurra en él

- A opción del contribuyente, el gasto puede amortizarse en un plazo que se determinará en base a la vida probable del depósito

\section{Gastos preoperativos generales}

- A opción del contribuyente, el gasto puede deducirse en el primer ejercicio en el que se inicie la producción

- A opción del contribuyente, el gasto puede amortizarse proporcionalmente en un plazo máximo de diez años

- La amortización se efectuará a partir del ejercicio en que se inicie la producción

- Se prevé la variación del plazo de amortización previa autorización de la SUNAT
- No se prevé la variación del plazo de amortización
- La amortización se efectuará a partir del ejercicio en que se llegue a la producción mínima legal

Es claro que en tanto el tratamiento tributario aplicable a los gastos de prospección y exploración y los gastos preoperativos generales difieren, toma especial relevancia la distinción técnica entre uno y otro (desde un punto de vista fiscal), para evitar posibles acotaciones por parte de la Administración Tributaria referidas al momento de la deducción del gasto o el método de amortización utilizado para cada caso, más aún cuando las normas contables no exigen hacer este tipo de distinciones.

Debe tenerse en consideración que la NIIF 6 resulta aplicable sólo a los desembolsos que se efectúan después de haber obtenido el derecho legal para desarrollar la actividad minera y antes de que se demuestre la factibilidad técnica y viabilidad comercial del proyecto. Ello genera que las empresas se vean obligadas a generar centros de costos distintos para los gastos efectuados entre estos dos momentos de manera tal que pueda identificarse a los desembolsos que se rigen por esta norma contable, pero nada obliga a generar distintos centros de costos para los gastos que califican como "prospección y exploración" y aquellos que califican como un "preoperativo general". 
Este criterio que obliga a distinguir entre gastos de "prospección y exploración" y "gastos preoperativos generales" ha sido compartido por el Tribunal Fiscal. Así, en la Resolución Nº2989-4-2010 ha manifestado lo siguiente:

Que en el caso de autos se tiene que por un lado la Ley Orgánica de Hidrocarburos prevé una regulación tributaria especial para el caso de los "gastos diferidos", siempre que estos califiquen como "gastos de exploración, desarrollo y/o inversiones" respecto de un lote de hidrocarburos, en tanto que la Ley del Impuesto a la Renta tiene una regulación general para el caso de gastos de organización, preoperativos iniciales y preoperativos originados por la expansión de actividades de la empresa, siendo que ambas normas condicionan la deducción de tales gastos al inicio de la extracción comercial, producción o explotación de la actividad por la que se incurrieron en dichos gastos. (p. 8)

Esta misma posición ha sido adoptada por la Administración Tributaria en el Informe $\mathrm{N}^{\circ}$ 22-2014-SUNAT/5D0000 del 2 de julio de 2014, que se pronuncia en relación a una serie de gastos administrativos (pago de alquileres de oficinas, fotocopias, planilla de personal de las gerencias administrativas y similares, intereses por financiamientos, etc.), todos efectuados durante la etapa de exploración petrolera, señalando que la deducción de este tipo de gastos preoperativos se rigen por lo dispuesto en el inciso g) del artículo $37^{\circ}$ de la Ley del Impuesto a la Renta y el inciso d) del artículo $21^{\circ}$ de su Reglamento, y no por las normas específicas de amortización del gasto preoperativo previsto en la Ley Orgánica de Hidrocarburos.

Tal interpretación resulta asimilable al régimen tributario minero y permite concluir bajo la misma lógica que los gastos de corte administrativo y general efectuados en una etapa previa al inicio de operaciones mineras se rigen por el inciso $\mathrm{g}$ ) del artículo $37^{\circ}$ de la Ley del Impuesto a la Renta, mientras que los gastos de prospección y exploración minera se rigen por las reglas específicas previstas en el artículo $74^{\circ}$ de la LGM.

\subsubsection{Gastos de desarrollo}

De otro lado, hay que diferenciar los gastos de prospección y exploración de los gastos de desarrollo que se efectúan aún en una etapa preoperativa. 
A decir de Rosado Silva (2003), los gastos de desarrollo son “(...) todos aquellos desembolsos necesarios para llevar el descubrimiento a una etapa de producción -comercial- que principalmente tienen que ver con trabajos para remover la tierra, excavar y construir caminos y túneles de acceso al depósito” (p. 121). Por su parte, el Tribunal Fiscal en la Resolución N 03113-1-2006, ha definido los gastos de desarrollo minero estableciendo que:

(...) comprenden las operaciones efectuadas antes de la explotación del yacimiento minero y que tienen como finalidad posibilitar y preparar el acceso al yacimiento minero y su producción, por lo tanto se establece que los gastos de desarrollo minero incluirán aquéllos incurridos a fin de realizar tales actividades (remoción de material estéril, desencape, apertura de socavones, etc.) que posibilitarán la explotación de la reserva del mineral (p.5).

Como hemos señalado, consideramos que la calificación de los gastos debe darse en función a su naturaleza y la finalidad para los cual fueron adquiridos, definiciones que obedecerán a criterios netamente técnicos. En ese sentido, entendemos que si el gasto tiene como finalidad la ubicación del mineral, o determinar sus dimensiones, calidad o viabilidad de su explotación calificará como gasto de exploración, mientras que si el gasto tiene como finalidad hacer posible el acceso o la producción del mineral calificará como gasto de desarrollo.

El límite y distinción entre las inversiones en prospección y exploración y de desarrollo es importantes desde un punto de vista tributario pues el tratamiento aplicable difiere dependiendo del tipo de gasto. Así y en relación al tratamiento tributario de los gastos de desarrollo, el segundo párrafo del artículo $75^{\circ}$ de la LGM establece lo siguiente:

Artículo $75^{\circ}$.-

Los gastos de desarrollo y preparación que permitan la explotación del yacimiento por más de un ejercicio, podrán deducirse íntegramente en el ejercicio en que se incurran o, amortizarse en dicho ejercicio y en los siguientes hasta un máximo de dos adicionales.

Haciendo un comparativo entre el tratamiento tributario de los gastos de prospección y exploración, con el tratamiento de los gastos de desarrollo, podemos advertir lo siguiente: 


\section{Tabla 3.2.}

Diferencias entre el tratamiento tributario de los gastos de prospección y exploración y los gastos de desarrollo

$$
\text { Prospección y Exploración }
$$

- A opción del contribuyente, el gasto puede deducirse en el ejercicio en que se incurra en él

- A opción del contribuyente, el gasto puede amortizarse en un plazo que se determinará en base a la vida probable del depósito

- La amortización se efectuará a partir del ejercicio en que se llegue a la producción mínima legal
Desarrollo

- A opción del contribuyente, el gasto puede deducirse en el ejercicio en que se incurra en él

- A opción del contribuyente, el gasto puede amortizarse en el ejercicio en que se incurrió en el gasto y en los siguientes hasta un máximo de dos adicionales

- La amortización se efectuará a partir del ejercicio en que se incurra en el gasto

- Alcanza a "lo invertido" en prospección y exploración.

- Sólo se refiere a "gastos" 18

Cabe advertir que la norma tributaria no fija un punto límite entre la ejecución de los gastos de prospección y exploración y los de desarrollo, es decir, no se tiene previsto un momento que para efectos fiscales signifique el fin de la ejecución de gastos de exploración y el inicio de la ejecución de gastos de desarrollo. Si bien una etapa sigue a la otra, desde un punto de vista técnico y atendiendo a la finalidad del gasto, los desembolsos para exploración en una etapa preoperativa pueden continuar y coexistir con desembolsos destinados al desarrollo o preparación.

En la práctica empresarial la distinción entre un gasto de prospección y exploración y uno de desarrollo obedecerá a criterios técnicos y presupuestarios que obligan a crear centros de costos distintos para mantener un mejor control de las inversiones; sin embargo, la distinción entre uno y otro tipo de gasto puede verse influenciada por el momento en que se obtiene la autorización o permiso legal para el inicio de la actividad minera de desarrollo.

Así, podría considerarse que los desembolsos que se efectúen con anterioridad a obtención de tal autorización legal califiquen como gastos de exploración, y sólo los

\footnotetext{
${ }^{18}$ La Administración Tributaria ha cuestionado la deducción de erogaciones que califican como "activo fijo" bajo las reglas aplicables a los gastos de desarrollo, pues bajo su entendimiento el artículo $75^{\circ}$ de la LGM, sólo es aplicable a "gastos", mientras que el "activo fijo" debe seguir las reglas de depreciación previstas en la Ley del Impuesto a la Renta.
} 
posteriores como gastos de desarrollo. Como hemos mencionado, consideramos que este criterio no debe regir para efectos tributarios pues la calificación del gasto como de exploración o desarrollo tendría que obedecer a su finalidad y destino, y no al título habilitante o la etapa legal en la que el gasto se ejecuta. Debe tenerse presente que la norma tributaria no prevé ni sujeta la distinción entre gastos de desarrollo y de exploración en función a la autorización legal o el título que habilita a desarrollar alguna de estas actividades mineras.

En esta misma línea, la distinción entre gastos de exploración y de desarrollo tampoco debería obedecer al tratamiento contable que corresponda a cada erogación. Así tenemos que la NIIF 6, resulta aplicable sólo a desembolsos que se efectúen antes de que se demuestre la factibilidad técnica y viabilidad comercial del proyecto, esto es antes de que se apruebe el Estudio de Factibilidad. Es así que contablemente es necesario distinguir entre gastos anteriores al Estudio de Factibilidad (que se rigen por la NIIF 6) y gastos posteriores al mismo (que se rigen por las normas contables específicas), pero ello de ningún modo podría implicar que se otorgue el tratamiento tributario de gastos de exploración a los primeros, y tratar como gastos de desarrollo para efectos fiscales a los segundos. Esta distinción generada por la aplicación de la NIIF 6 podría ser válida para efectos contables pero no para efectos tributarios.

\subsubsection{Gastos de cateo}

Tal y como hemos mencionado, el inciso o) del artículo $37^{\circ}$ de la Ley del Impuesto a la Renta se refiere a la regulación de los gastos en "exploración”. Por su parte, el artículo $74^{\circ}$ de la LGM se refiere no sólo a los gastos de exploración, sino que otorga el mismo tratamiento a los gastos de "prospección". Si bien ambos términos técnicamente son distintos, entendemos que la equiparación en el tratamiento tributario es lógico pues las inversiones que se realizan en esta primera etapa de la vida de la mina gozan de las mismas características, esto es, son inversiones que se realizan a fin de determinar la existencia del mineral y la viabilidad del proyecto minero, y que sólo tendrán un correlato con los ingresos que se generen una vez que se haya dado inicio a la explotación del proyecto.

No sucede lo mismo con los denominados gastos de "cateo", concepto mencionado en el artículo $1^{\circ}$ de la LGM como la acción conducente a poner en 
evidencia indicios de mineralización por medio de labores mineras elementales, y que supone acciones de búsqueda de mineral bastante preliminares a diferencia de la prospección que supone el uso de métodos y tecnología adicionales. Como puede verse, tenemos que la LGM en su primer capítulo diferencia el concepto de cateo de los conceptos de prospección y desarrollo; no obstante no existe mención a los gastos de cateo ni en la Ley del Impuesto a la Renta ni en el artículo $74^{\circ}$ de la LGM. Es decir, si bien la Ley General de Minería distingue el cateo de la prospección, sólo otorga en forma expresa un tratamiento tributario a los gastos de prospección y de exploración.

Entendemos por tanto que, al tratarse de gastos muy iniciales y poco significativos, no recibirían el tratamiento tributario específico previsto en la LGM, sino que serían tratados bajo el régimen general, esto es, como gastos preoperativos regulados por el inciso g) del artículo $37^{\circ}$ de la Ley del Impuesto a la Renta. Esta diferencia resulta importante, pues de ser así habría que separar estos conceptos y otorgarles un tratamiento tributario diferenciado. Así, mientras que los gastos de cateo podrían amortizarse en el primer ejercicio de iniciada la producción o amortizarse en el plazo máximo de diez años, los gastos de prospección podrían amortizarse a partir del inicio de la producción mínima legal en el plazo de la vida probable del depósito o deducirse en el ejercicio en que se incurrió en el gasto.

Consideramos que aunque por materialidad esta distinción podría no ser relevante, desde un punto de vista técnico jurídico sí lo es. Entendemos que en la medida que la propia LGM diferencia el cateo de la prospección, sería necesario que el artículo $74^{\circ}$ de dicha norma mencione expresamente a los gastos de cateo para que proceda la aplicación del tratamiento tributario especial previsto en dicha norma. Pese a ello, somos de la opinión que la norma no debería otorgar tratamientos diferenciados a los gastos de cateo y los gastos de prospección y exploración, pues finalmente el cateo sería sólo una fase muy preliminar de las actividades de prospección y la distinción entre la regulación fiscal de uno y otro tipo de gasto no tendría una justificación técnica.

\subsubsection{Corolario}

Podemos concluir en mérito de todo lo antes señalado que la distinción entre los distintos tipos de desembolsos que se presentan antes del inicio de la etapa productiva en minería: gastos de prospección y exploración, gastos de cateo, gastos de desarrollo y 
gastos preoperativos generales, resulta importante desde un punto de vista fiscal pues cada tipo de erogación tiene un tratamiento tributario aplicable distinto y específico que hay que observar a fin de evitar acotaciones por parte de la Administración Tributaria en relación al ejercicio en que corresponde su deducción o el método, plazo o cómputo de la amortización aplicada.

Ahora bien, cabe preguntarnos si se justifica el otorgar un tratamiento tributario disímil para cada tipo de gasto que obliga además a una serie de controles adicionales y a una mayor exposición a contingencias tributarias. Así nos cuestionamos: ¿es necesario desde un punto de vista técnico y jurídico que los distintos tipos de gastos se deduzcan y amorticen de distinta forma?, o es que simplemente la técnica legislativa utilizada obliga innecesariamente a efectuar distinciones para efectos formales cuando no hay razones de fondo para ello.

Sobre el particular, consideramos que si el principio que rige la deducción de los gastos en una etapa pre productiva es que éstos deban diferirse a ejercicios en los que existan ingresos, no cabría hacer mayor distinción entre el tratamiento tributario otorgado a cualquier tipo de desembolso efectuado en una etapa previa al inicio de la extracción. En otras palabras, todos estos desembolsos (cateo, prospección, exploración, desarrollo, preoperativos generales), podrían seguir perfectamente el tratamiento previsto en el artículo $74^{\circ}$ de la LGM. En efecto, en su gran mayoría se tratan de gastos que influyen en la generación de las rentas futuras a obtenerse durante la explotación del yacimiento minero, por tanto, si se opta por la amortización es lógico que esta se de a lo largo de la vida del depósito minero, y no en plazos de hasta tres o diez años previstos para los gastos de desarrollo o los preoperativos generales, respectivamente, plazos que no vinculan el gasto con el período en que éstos influyen en la generación de rentas y que por tanto carecen de mayor sustento técnico.

De otro lado, los gastos (de cualquier tipo) que no se reconozcan contablemente como activos por no tener mayor influencia en la generación de rentas futuras, bien podrían seguir la regla de deducción en el ejercicio de "incurrido" prevista en el artículo $74^{\circ}$ de la LGM, lo que permitiría además conciliar el tratamiento contable con el tratamiento tributario.

Adicionalmente, al permitir la deducción de las inversiones pre productivas -de cualquier tipo- en el ejercicio de "lo incurrido", se genera un incentivo tributario pues el 
inversionista optará por esta medida si es que obtiene a la par rentas provenientes de otras concesiones o Unidades Económicas o Administrativas que podrá compensar con las pérdidas que se generen como consecuencia de la deducción de las inversiones en las concesiones preoperativas. El poder deducir del Impuesto a la Renta todo desembolso efectuado en el ejercicio, en nuevos proyectos preoperativos o exploratorios constituye un incentivo fiscal importante para que el inversionista minero realice o prosiga con actividades de exploración y desarrollo.

El caso más discutible pudiera ser el de las inversiones en desarrollo, pues la norma que permite la amortización en el ejercicio en que se incurra en ellos o hasta en los dos años siguientes, es en realidad una norma que busca incentivar la inversión minera pues permite tomar el gasto de forma inmediata o en un plazo muy corto (máximo tres años); sin embargo, debemos tener presente que en el caso de las inversiones en desarrollo que se ejecutan en etapas preoperativas, el ejercicio en que "se incurre en el gasto" es un ejercicio en el que no se ha generado rentas, y por tanto, la deducción bajo dicha norma no conlleva un incentivo, sino por el contrario logra un efecto no deseado consistente en la generación de pérdidas tributarias precisamente porque no hay un correlato con ingresos que los absorban.

Como puede verse, incluso para las inversiones en desarrollo minero en etapa preoperativa sería conveniente seguir el tratamiento previsto por el artículo $74^{\circ}$ de la LGM, en primer lugar porque si se opta por la amortización se lograría generar un correlato entre los ingresos y el gasto evitando el innecesario reconocimiento de pérdidas tributarias; y de otro lado, si a criterio del titular de la actividad minera lo conveniente sería deducir el gasto en el ejercicio en que se incurra (probablemente por existir certeza sobre la factibilidad del proyecto y seguridad en que las pérdidas tributarias se arrastren y compensen en un corto plazo), puede optarse igualmente por la deducción en el ejercicio de "lo incurrido", generando el reconocimiento no en tres años sino sólo en uno.

Teniendo en consideración lo señalado, y en aras de otorgar uniformidad al tratamiento tributario de los desembolsos efectuados antes del inicio de la etapa productiva bajo criterios técnicos que lleven a conciliar el tratamiento contable con el tributario, otorgar incentivos a la inversión en exploración y desarrollo, evitar la generación de contingencias tributarias y dar seguridad jurídica al inversionista en la interpretación y aplicación de las normas, consideramos recomendable una 
modificación normativa que abarque dentro de los alcances del artículo $74^{\circ}$ de la LGM a todo desembolso efectuado antes de la producción mínima legal, y que incluya tanto a los gastos de prospección y exploración, como a los gastos de desarrollo, cateo y los preoperativos generales.

Como referencia tenemos que para el caso de la deducción de desembolsos preoperativos en el sector hidrocarburos, el artículo $53^{\circ}$ del Texto Único Ordenado de la Ley Orgánica de Hidrocarburos (Decreto Supremo N 042-2005-EM, 2005) prevé un tratamiento tributario uniforme para los gastos de exploración y desarrollo, y extiende el alcance de dicha norma para "las inversiones" que se efectúen antes del inicio de la extracción comercial ${ }^{19}$. Como vemos, a diferencia de la norma aplicable en el sector minero, la norma para el sector hidrocarburos pretende abarcar y dar un solo tratamiento tributario a toda erogación generada en etapa preoperativa, sin hacer distinción entre el tipo de gasto efectuado ${ }^{20}$.

${ }^{19}$ Según lo dispuesto por el primer párrafo del artículo $53^{\circ}$ de la Ley Orgánica de Hidrocarburos:

Los gastos de exploración y desarrollo, así como las inversiones que realicen los contratistas hasta la fecha en que se inicie la extracción comercial de Hidrocarburos, incluyendo el costo de los pozos, serán acumulados en una cuenta cuyo monto, a opción del Contratista y respecto de cada Contrato, se amortizará de acuerdo con cualesquiera de los métodos o procedimientos siguientes (...). (Subrayado agregado).

${ }^{20}$ Cabe señalar que el término "inversión” no ha sido suficiente para abarcar -sin controversia- a los gastos preoperativos generales, pues dicho término está relacionado con la colocación de capitales, o erogaciones para adquirir bienes o instrumentos de producción que tengan como fin directo la generación de ingresos por la venta de bienes o prestación de servicios. 


\section{CAPÍTULO IV: OPCIONES PREVISTAS POR LA NORMA TRIBUTARIA PARA LA DEDUCCIÓN DE LOS GASTOS DE PROSPECCIÓN Y EXPLORACIÓN MINERA ANTES DEL INICIO DE LA ETAPA PRODUCTIVA}

De acuerdo a lo señalado por el inciso o) del artículo $37^{\circ}$ de la Ley del Impuesto a la Renta, los gastos de exploración, preparación y desarrollo en que incurren los titulares de actividades mineras podrán ser deducidos en el ejercicio en que se incurran o deberán ser amortizados en los plazos y condiciones que señale la LGM. Por su parte, el artículo $74^{\circ}$ de la LGM, dispone lo siguiente:

El valor de adquisición de las concesiones, se amortizará a partir del ejercicio en que de acuerdo a ley corresponda cumplir con la obligación de producción mínima, en un plazo que el titular de actividad minera determinará en ese momento, en base a la vida probable del depósito, calculada tomando en cuenta las reservas probadas y probables y la producción mínima obligatoria de acuerdo a ley. El plazo así establecido deberá ser puesto en conocimiento de la Administración Tributaria al presentar la Declaración Jurada Anual del Impuesto a la Renta correspondiente al ejercicio en que se inicie la amortización, adjuntando el cálculo correspondiente.

El valor de adquisición de las concesiones incluirá el precio pagado, o los gastos de petitorio, según el caso.

Igualmente, incluirá lo invertido en prospección y exploración hasta la fecha en que de acuerdo a ley corresponda cumplir con la producción mínima, salvo que se opte por deducir lo gastado en prospección y/o exploración en el ejercicio en que se incurra en dichos gastos

$(\ldots)$.

Como vemos la norma tributaria minera establece dos sistemas para deducir los gastos de prospección y exploración minera efectuados antes de inicio de la etapa productiva (lo que para efectos jurídicos corresponde a la fecha en que de acuerdo a ley corresponde cumplir con la producción mínima), sobre las que el contribuyente deberá optar: 
a) Amortizar lo invertido a partir del ejercicio en que de acuerdo a ley corresponda cumplir con la producción mínima en un plazo determinado en base a la vida probable del depósito, el mismo que se calcula tomando en cuenta las reservas probadas y probables y la producción mínima obligatoria de acuerdo a ley; o,

b) Deducir lo gastado en el ejercicio en que se incurra en dichos gastos.

Asimismo, de acuerdo a lo señalado por el último párrafo del artículo $75^{\circ}$ de la LGM, la opción sobre un sistema u otro se ejercitará respecto de los gastos de cada ejercicio. Agrega que una vez escogido un sistema esto no podrá ser variado.

En tal sentido, año a año el contribuyente deberá elegir el tratamiento que aplicará sobre los desembolsos efectuados en cada ejercicio decidiendo si opta por amortizarlos o deducirlos como gasto. Podemos por tanto encontrarnos ante casos en que se opte por la amortización para determinados ejercicios, y en otros se opte por la deducción como gasto.

Es importante recalcar que el plazo elegido por el contribuyente respecto de cada ejercicio es invariable.

En el presente Capítulo desarrollaremos en amplitud ambas opciones, expondremos los distintos criterios interpretativos surgidos en relación a las mismas y exploraremos alternativas normativas que permitan eliminar las dudas o controversias en torno a aplicación, así como otras que permitan un tratamiento más acorde con la realidad actual y que brinden un mayor incentivo fiscal para el desarrollo de las actividades de exploración minera.

\subsection{Generalidades sobre la deducción de gastos efectuados en etapas preoperativas}

Antes de analizar a profundidad cada una de las opciones para la deducción de lo invertido en prospección y exploración previstas en el artículo $74^{\circ}$ de la LGM, consideramos importante revisar de manera general el tratamiento tributario aplicable a los gastos que se efectúan en etapas preoperativas a fin de entender la lógica que subyace a su regulación, sus implicancias, vinculación y similitudes con la regulación aplicable a los gastos de prospección y exploración minera que venimos tratando.

Como hemos señalado, los gastos en prospección y exploración que se efectúan en una etapa preoperativa implican para el inversionista minero desembolsos bastante 
significativos a realizarse por un largo período de tiempo. Dichos gastos se efectúan con la finalidad de obtener ingresos futuros que se generarán una vez que se de inicio a la explotación del yacimiento (si es que las actividades de exploración resultan exitosas y la extracción del mineral viable).

Tenemos entonces una situación en la que estos gastos no tienen correlato con los ingresos que estos generen pues ambos se producen en diferentes períodos de tiempo.

Ahora bien, como sabemos el Impuesto a la Renta grava la Renta Neta, esto es la renta menos los gastos y costos incurridos para generarla o mantenerla. Gravar los ingresos sin considerar la deducción de los gastos necesarios para su generación conllevaría la vulneración al Principio de Capacidad Contributiva, principio que implica que el tributo guarde relación con la capacidad económica del sujeto obligado. En relación al Principio de Capacidad Contributiva, el Tribunal Constitucional en la Sentencia recaída en el Expediente $\mathrm{N}^{\circ}$ 033-2004-AI/TC (2004) ha señalado que:

(...) la capacidad contributiva tiene un nexo indisoluble con el hecho sometido a imposición; es decir, siempre que se establezca un tributo, éste deberá guardar íntima relación con la capacidad económica de los sujetos obligados, ya que sólo así se respetará la aptitud del contribuyente para tributar o, lo que es lo mismo, sólo así el tributo no excederá los límites de la capacidad contributiva del sujeto pasivo (...) (párrafo 12).

En observancia del Principio de Capacidad Contributiva corresponde entonces la deducción de los gastos aún en el caso que estos se produzcan o desembolsen en un período preoperativo y las rentas se obtengan años después durante una etapa operativa. En este sentido, será indispensable que los gastos preoperativos generados en un determinado ejercicio, se asocien y deduzcan de las rentas que se generen en el futuro.

Para ello, es necesario un mecanismo que permita asociar y llevar dichos gastos a los ejercicios futuros en que se generan tales beneficios. Es allí donde toma especial relevancia la figura del gasto diferido.

Sobre el particular, el Diccionario Kohler para Contadores define al gasto diferido como "la erogación no reconocida como costo de las operaciones del período en que se incurre, sino que se lleva adelante para eliminarla en uno o más períodos futuros" (Cooper, 2005 p. 54). 
Por su parte, Bernstein (1995) ha señalado que los gastos diferidos:

(...) son aquellos que "representan gastos ya producidos que se retrasan al futuro porque está previsto que beneficien a futuros ingresos o porque representan una verdadera asignación de costes a operaciones futuras" (...) "de acuerdo al postulado contable de equiparación de ingresos y gastos, si un coste producido en un período va a beneficiar a uno o varios períodos futuros, mediante una contribución a los ingresos o una reducción a los costes, ese coste debe diferirse hasta el correspondiente período futuro. Así pues, si una empresa incurre en costes sustanciales de puesta en marcha para hacer funcionar unas instalaciones nuevas, mejores o más eficientes, puede diferir éstos costes y cargarlos a los períodos que previsiblemente se van a beneficiar de ellos ( $p$. $87)$.

Como puede verse, la figura de "gasto diferido" brinda una solución al reconocimiento de gastos en etapas preoperativas al prever que aquellos desembolsos que influyan en la generación de rentas futuras se difieran al futuro y se reconozcan conjuntamente con los ingresos. Este correlato entre gastos e ingresos por el diferimiento de los primeros permite gravar la renta neta del contribuyente sin afectar su capacidad contributiva.

Bajo la figura de "gasto diferido" subyace el criterio contable de correlación de gastos con ingresos desarrollado en el Marco Conceptual según lo siguiente:

Los gastos se reconocen en el estado de resultados sobre la base de una asociación directa entre los costos incurridos y la obtención de partidas específicas de ingresos. Este proceso, al que se denomina comúnmente correlación de costos con ingresos de actividades ordinarias, implica el reconocimiento simultáneo o combinado de unos y otros, si surgen directa y conjuntamente de las mismas transacciones u otros sucesos; por ejemplo, los diversos componentes del gasto que constituyen el costo de las mercancías vendidas se reconocen al mismo tiempo que el ingreso derivado de la venta de los bienes. No obstante, la aplicación del proceso de correlación bajo este Marco Conceptual no permite el reconocimiento de partidas en el balance que no cumplan la definición de activo o pasivo (párrafo 4.50).

Cuando se espera que los beneficios económicos surjan a lo largo de varios períodos contables, y la asociación con los ingresos puede determinarse únicamente de forma genérica o indirecta, los gastos se reconocen en el estado de resultados utilizando procedimientos sistemáticos y racionales de distribución. Esto es, a menudo, necesario para el reconocimiento de los gastos relacionados con el uso de activos tales como los que componen las propiedades, planta y equipo, la plusvalía, las patentes y las marcas, 
denominándose en estos casos al gasto correspondiente depreciación o amortización. Los procedimientos de distribución están diseñados a fin de que se reconozca el gasto en los periodos contables en que se consumen o expiran los beneficios económicos relacionados con estas partidas (párrafo 4.51).

Dentro del estado de resultados, se reconoce inmediatamente como tal un gasto cuando el desembolso correspondiente no produce beneficios económicos futuros, o cuando, y en la medida que, tales beneficios futuros no cumplen o dejan de cumplir las condiciones para su reconocimiento como activos en el balance (párrafo 4.52).

De lo señalado por las normas contables podemos llegar a las siguientes conclusiones en relación al reconocimiento de los gastos:

- Los gastos se reconocen en aplicación del procedimiento de correlación de costos con los ingresos. Este procedimiento implica el reconocimiento simultáneo de ambos.

- Cuando se espera beneficios económicos a lo largo de varios períodos, y la asociación con los ingresos puede determinarse únicamente de forma genérica o indirecta, los gastos se reconocen mediante depreciación o amortización. Estos procedimientos tienen como finalidad reconocer el gasto en los períodos en que se consumen los beneficios relacionados con los gastos.

- Si un desembolso no produce beneficios futuros, se reconoce inmediatamente como gasto del ejercicio.

- También se reconocerá inmediatamente un desembolso como gasto del ejercicio, si produciendo beneficios futuros, no se cumple las condiciones para su reconocimiento como activo en el balance, o se dejan de cumplir tales condiciones.

En resumen, de acuerdo al criterio contable de correlación de gastos con ingresos, los desembolsos que influyan en la generación de rentas futuras se deben reconocer conjuntamente con los ingresos. Cuando los gastos influyen en la generación de beneficios económicos por varios períodos, dicho reconocimiento se efectúa a través de la depreciación o amortización.

De otro lado, las normas contables prevén también un tratamiento para aquellos gastos preoperativos que no influyen en la obtención de beneficios futuros, señalando 
que los mismos deben deducirse como gasto del ejercicio.

Si bien el concepto de "gasto diferido" y el criterio contable de correlación de gastos con ingresos no ha sido recogido expresamente por la norma tributaria (como sí lo ha hecho por ejemplo la legislación española) ${ }^{21}$, tanto la doctrina como la jurisprudencia han desarrollado dichos conceptos y zanjado su aplicación en el tratamiento tributario de los gastos preoperativos.

Existen diversos pronunciamientos del Tribunal Fiscal referidos al diferimiento de los gastos efectuados en etapas preoperativas y la correlación de estos con los ingresos futuros, entre los que podemos citar a los siguientes:

\section{- Resolución del Tribunal Fiscal $N^{\circ}$ 00467-5-2003 (2003)}

El contribuyente difirió gastos de personal del ejercicio 1995 a 1996 al considerar que se encontraban directamente vinculados a proyectos inmobiliarios cuyos resultados se devengarían en dicho ejercicio en aplicación del principio de cotejo o matching de costos con ingresos relacionados, resultando aplicable lo dispuesto en el inciso g) de la Ley del Impuesto a la Renta.

La Administración Tributaria observó la deducción del gasto en el ejercicio 1996 al considerar que este era deducible en 1995 en aplicación del inciso a) del artículo $57^{\circ}$ de la Ley del Impuesto a la Renta. Al respecto, señaló que el argumento del contribuyente no tenía asidero legal.

El Tribunal Fiscal citando a Jan R. Williams, señaló que:

en virtud del concepto de imputación, se requiere que para determinar la utilidad neta de un ejercicio específico se imputen al ingreso del ejercicio los costos con los cuales está relacionado. En tal sentido, al igual que lo mencionado en las NIC, si el ingreso se difiere a ejercicios posteriores, también deben diferirse los costos conexos $(\ldots)$.

Adicionalmente, precisó que lo dispuesto en el inciso g) del artículo $37^{\circ}$ de la

\footnotetext{
${ }^{21}$ Ver sobre el particular el artículo 10.1 de la Ley 27/2014 del Impuesto sobre Sociedades Español (2014), norma que establece que:

“1. Los ingresos y gastos derivados de las transacciones o hechos económicos se imputarán al período impositivo en que se produzca su devengo, con arreglo a la normativa contable, con independencia de la fecha de su pago o de su cobro, respetando la debida correlación entre unos y otros" (subrayado agregado).
} 
Ley del Impuesto a la Renta -que regula la deducción de los gastos preoperativos generales- guarda coherencia con lo establecido en las normas y doctrina contables, dado que permiten relacionar los gastos preoperativos con los ingresos.

Agregó que bajo el razonamiento planteado, correspondía que los gastos se reconocieran en el ejercicio en que se producía la transferencia del bien, en aplicación del concepto de imputación o asociación entre ingresos y gastos, debiendo tenerse en cuenta que a tal fin, debía observarse los criterios contables que hicieran posible tal reconocimiento, es decir, que se haya acreditado la incidencia de los gastos en la generación de ingresos futuros, que el producto o proceso se encontrara definido, que la factibilidad técnica del producto pueda ser demostrada, que se acredite la existencia de un mercado y que se pueda contar con los recursos necesarios para completar el proyecto y comercial el producto.

Finalmente, mantuvo el reparo al considerar que el contribuyente no habría sustentado el diferimiento de los gastos al no haber identificado los proyectos y sus características, tales como las metas esperadas realizadas, los trabajos propios del proyecto, los resultados del estudio y proyección efectuados, entre otros, que permitan demostrar la necesidad de diferir tales gastos hasta el ejercicio siguiente, así como tampoco se identificó los ingresos que provienen de los proyectos y como se vinculan a los gastos reparados (p. 12-14).

\section{- Resolución del Tribunal Fiscal $N^{\circ}$ 5349-3-2005 (2005)}

La Administración Tributaria observó la amortización de diversos estudios y proyectos debido a que se trataban de obras que aún no habían sido explotadas o producidas, al considerar que en aplicación del inciso g) del artículo $37^{\circ}$ de la Ley del Impuesto a la Renta, la amortización debería efectuarse a partir del ejercicio en que se inicie la explotación o producción.

Asimismo, citó a la Norma Internacional de Contabilidad 1 (NIC 1), referida a la presentación de estados financieros, la misma que señala que una empresa debe preparar sus estados financieros, entre otros, sobre la base contable del devengado, precisando que los gastos se reconocen en el estado de ganancias y pérdidas en base a una asociación directa entre los costos incurridos y las partidas de ingresos (concepto de asociación). Señaló asimismo que de acuerdo 
al concepto de asociación, para efecto de la aplicación del devengado es indispensable vincular directamente el ingreso que aparece en el estado de resultados con todos los gastos en los que se incurre para la generación de dicho ingreso, por existir una relación causa y efecto entre los ingresos y gastos.

En mérito de ello, concluyó que los estudios y proyectos analizados calificaban como gastos diferidos por haber sido incurridos a efecto de beneficiar ejercicios posteriores y que para efecto de su deducción debían encontrarse asociados con los ingresos obtenidos (p. 9-13).

\section{- Resolución del Tribunal Fiscal $N^{\circ}$ 02989-4-2010 (2010)}

La Administración Tributaria observó la deducción en el ejercicio de diversos gastos (gastos de personal, alquileres, comunicaciones, materiales, servicios, etc.) efectuados por una empresa de hidrocarburos en una etapa preoperativa, al considerar que los mismos no habrían cumplido con el principio de causalidad toda vez que no se habían generado ingresos. Asimismo consideró que dichos gastos debían activarse en base a lo establecido en el artículo $53^{\circ}$ de la Ley Orgánica de Hidrocarburos, el inciso g) del artículo $37^{\circ}$ de la Ley del Impuesto a la Renta y el inciso d) del artículo $21^{\circ}$ de su Reglamento, y recién ser objeto de amortización a partir del inicio de la extracción comercial.

El Tribunal Fiscal señaló que de acuerdo al postulado contable de equiparación, asociación o "matching" de ingresos y gastos, debe entenderse que el primer año al que hace referencia el Reglamento de la Ley del Impuesto a la Renta no puede ser otro que el de inicio de producción o explotación.

En tal sentido, concluyó que los gastos preoperativos -diferidos-, toda vez que representan gastos ya producidos que beneficiarán la realización de operaciones futuras, únicamente podían deducirse a partir del año en que se iniciara la extracción comercial, confirmando el reparo (p. 7-9).

De lo antes señalado podemos concluir que tanto a nivel de normas contables como a nivel jurisprudencial y doctrinario, los desembolsos efectuados en etapas preoperativas en la medida que se vinculen con la generación de ingresos futuros, deben diferirse y reconocerse a partir del ejercicio en que se generen los ingresos asociados y deducirse bajo un criterio de correlación de gastos con los ingresos con los que se encuentren vinculados a través de su amortización, pues sólo así se permitirá gravar la renta neta 
del contribuyente sin afectar su capacidad contributiva.

\subsection{Primera opción: Amortización del gasto}

De acuerdo a lo señalado por el artículo $74^{\circ}$ de la LGM, el contribuyente puede optar por deducir lo invertido en prospección y exploración hasta la fecha en que de acuerdo a ley corresponda cumplir con la producción mínima, incluyendo tal inversión dentro del valor de adquisición de la concesión, el cual se amortizará en un plazo que el titular de la actividad minera determinará en ese momento, en base a la vida probable del depósito, calculada tomando en cuenta las reservas probadas y probables y la producción mínima obligatoria de acuerdo a ley.

La amortización de los gastos de prospección y exploración tiene su lógica en la imputación de gastos que influirán en la explotación de la mina y la generación de ingresos a lo largo de la vida del depósito minero, pues sólo difiriendo estos gastos hasta la etapa productiva se logrará gravar la renta neta y respetar la real capacidad contributiva del sujeto del impuesto, generando así un correlato entre los gastos deducibles y los ingresos que se generen. En tal sentido, al interpretar la norma deberá tenerse en consideración la finalidad u objetivo que guió su emisión.

Del texto de la norma podemos partir de las siguientes premisas: (i) el tratamiento del artículo $74^{\circ}$ aplica a lo invertido hasta la fecha en que de acuerdo a ley corresponde cumplir con la producción mínima; (ii) la amortización se inicia a partir de dicho ejercicio; (iii) el plazo de amortización se determina en dicho ejercicio; (iv) el plazo se fija en función a la vida probable del depósito; y, (v) la vida probable del depósito se calcula tomando en consideración las reservas probadas y probables, así como la producción mínima obligatoria de acuerdo a ley.

Asimismo, debemos tener en consideración lo señalado por el artículo $12^{\circ}$ del Reglamento del Título Noveno de la Ley General de Minería referido a las Garantías y Medidas de Promoción a la Inversión en la actividad minera (Decreto Supremo $\mathrm{N}^{\circ} 024$ 93-EM, 1993), -en adelante “el Reglamento del Título Noveno”- que a la letra señala:

En caso que el titular de actividad minera agrupe sus concesiones mineras en unidades económicas administrativas, el plazo de amortización del valor de adquisición de las concesiones se determinará en base a las reservas probadas y probables de la Unidad y a la producción anual de ella. 
Igual norma se aplicará para determinar el plazo de amortización de los gastos de exploración en que se incurra.

Si una concesión minera se incluyera en una Unidad Económica Administrativa una vez iniciado el plazo de amortización del valor de adquisición o de los gastos de exploración en que se hubiera incurrido, el plazo de amortización deberá reajustarse en base al que le corresponda como integrante de la Unidad.

Los plazos de amortización, tratándose de Unidades Económico Administrativas se reajustarán al cierre de cada ejercicio, considerando la disminución o aumento de reservas probadas y probables que sufra la Unidad como resultado de la inclusión o exclusión de una o más concesiones.

Como puede verse, la norma no hace expresa mención al método de amortización aplicable. Asimismo, la norma no desarrolla procedimiento alguno en caso la vida del depósito se extienda por el descubrimiento de nuevas reservas en el mismo proyecto, o cuál sería el tratamiento aplicable en el supuesto que la vida proyectada de la mina sea menor al plazo fijado, por ejemplo, por una menor producción a la estimada. Finalmente, mientras que la Ley establece que la vida probable del depósito se calcula tomando en consideración la producción mínima obligatoria, el Reglamento del Título Noveno hace referencia a la producción anual (en el caso de la constitución de unidades económicas administrativas).

En el presente subcapítulo, abordaremos y desarrollaremos la opción de amortización regulada en el artículo $74^{\circ}$ de la LGM, así como las controversias interpretativas surgidas en relación a ella y las alternativas que permitan mejorar su regulación y/o aplicación en el contexto actual.

\subsubsection{La amortización tributaria: concepto y fines.}

Como hemos señalado en capítulos anteriores, en aplicación del criterio de correlación de gastos con ingresos un desembolso que se vincule con la generación de rentas futuras debe diferirse y deducirse conjuntamente con los ingresos que este desembolso genere en uno o varios ejercicios. Ahora bien, tratándose de gastos que tienen correlato con la generación de rentas en varios períodos tributarios, tal deducción procederá a través de un procedimiento sistemático y racional de distribución del gasto: la amortización. La finalidad de la amortización es entonces distribuir el gasto a lo largo de los períodos en 
los cuales se generaron los beneficios económicos relacionados con el mismo.

Así tenemos que de acuerdo a lo señalado por el párrafo 4.51 del Marco Conceptual:

Cuando se espera que los beneficios económicos surjan a lo largo de varios períodos contables, y la asociación con los ingresos puede determinarse únicamente de forma genérica o indirecta, los gastos se reconocen en el estado de resultados utilizando procedimientos sistemáticos y racionales de distribución. Esto es, a menudo, necesario para el reconocimiento de los gastos relacionados con el uso de activos tales como los que componen las propiedades, planta y equipo, la plusvalía, las patentes y las marcas, denominándose en estos casos al gasto correspondiente depreciación o amortización. Los procedimientos de distribución están diseñados a fin de que se reconozca el gasto en los periodos contables en que se consumen o expiran los beneficios económicos relacionados con estas partidas (subrayado agregado).

Este procedimiento de diferimiento y distribución del gasto, permite un correlato entre gastos e ingresos que garantiza un gravamen sobre la renta neta del contribuyente y por tanto el respeto a su capacidad contributiva, en tanto la renta neta no puede significar otra cosa que el beneficio empresarial como verdadero indicador de la capacidad contributiva luego de excluir los costos de producción.

A decir de Colao Marín (1995), la amortización permite deducir el costo de un bien en diversos períodos en el que el bien es utilizado resolviendo la exigencia de gravar sobre rentas netas frente a la imposibilidad de deducir los costos de los bienes de producción que no se consumen ni incorporan en forma directa al proceso productivo sino que se consumen en forma indirecta a lo largo de su uso prolongado en el tiempo (p. 191).

De otro lado, resulta relevante para nuestros fines diferenciar los dos procedimientos de distribución de gastos existentes: “depreciación” y “amortización”.

Al respecto, la depreciación constituye un procedimiento de distribución de costes basado en el uso de los bienes y que es aplicable a los activos fijos tangibles que se desgastan por su uso u obsolescencia (depreciación económica).

Por su parte, la "amortización" es un procedimiento de distribución de gastos aplicable a intangibles que no son susceptibles de depreciarse en un sentido estricto del término, o partidas que se amortizan al distribuirse en el tiempo el importe de las 
inversiones efectuadas (depreciación jurídica). Así tenemos que mientras que la depreciación se asigna según el uso y desgaste de los bienes, la amortización se asigna según el transcurso del tiempo (Godoy Fajardo, 2008, p. 285-286).

Sobre el particular Colao Marín (1995), señala que en la amortización el elemento más importante es el transcurso del tiempo, tratándose de una depreciación peculiar que no provoca el proceso de envejecimiento debido al uso, sino que provoca la reducción de las expectativas de uso por el simple transcurso del tiempo (p. 116). Por su parte, García Novoa (2001), agrega que a diferencia de los bienes corporales, en el caso de la amortización nos encontramos ante una "depreciación jurídica" que no dependerá del uso del bien, sino de (por ejemplo) la vigencia temporal del derecho a la concesión (p. 100).

En mérito de lo antes señalado, podemos concluir que la amortización es un procedimiento sistemático y racional de asignación o distribución de los gastos que se vinculan con la generación de beneficios futuros en varios ejercicios. La amortización está diseñada para que se reconozca el gasto en los períodos en que se consume o expira el beneficio económico con el que está vinculado, reconocimiento que se realiza en función a la reducción de las expectativas dadas por el transcurso del tiempo, el que puede corresponder por ejemplo al de la vigencia de una concesión o la vida esperada del depósito minero. La amortización corresponde entonces a una "depreciación jurídica" que está basada en el simple transcurso del tiempo hasta que los beneficios futuros expiren, a diferencia de la "depreciación económica" que toma como base para asignar los gastos el uso y obsolescencia de los bienes corporales.

\subsubsection{Producción mínima obligatoria (PMO)}

A fin de analizar las posibilidades previstas por la Ley para la deducción de lo invertido en prospección y exploración, resulta necesario revisar previamente el concepto de Producción Mínima Obligatoria (en adelante "PMO"), en tanto el artículo $74^{\circ}$ de la LGM lo menciona como un hito determinante para su aplicación. Así, la norma establece que el PMO tiene implicancias en lo siguiente:

(i) El tratamiento previsto en el artículo $74^{\circ}$ de la LGM aplica a lo invertido en prospección y exploración hasta la fecha en que de acuerdo a ley corresponde cumplir con la producción mínima. 
(ii) La amortización de lo invertido en prospección y exploración se inicia a partir del ejercicio en que de acuerdo a ley corresponda cumplir con la obligación de producción mínima.

(iii) El plazo de amortización se determinará en ejercicio en que de acuerdo a ley corresponda cumplir con la obligación de producción mínima.

La PMO es una obligación administrativa que exige al titular de la concesión una producción mínima en la concesión otorgada y que tiene como premisa que el otorgamiento de la concesión por parte del Estado obliga a su explotación. Al respecto, De la Vega Rengifo (2012), señala lo siguiente:

La producción mínima obligatoria no es otra cosa que el piso o mínimo de producción que el Estado exige al titular de la concesión minera por la concesión otorgada. En esa misma línea, el plazo establecido para el cumplimiento de la producción mínima obligatoria dispuesto por la norma, se refiere a un parámetro que busca determinar un período máximo de tiempo en que el titular de una concesión minera puede mantener la concesión sin productividad (p. 30).

Por un lado, la exigencia de una producción mínima se sustenta en la necesidad de que el territorio concesionado sea aprovechado por el titular de una manera rentable obligando al titular a la búsqueda exitosa de reservas mineras y a su explotación. De otro lado, al llegar a la producción mínima, el titular demuestra que el proyecto minero ha obtenido índices mínimos de rendimiento aceptables. Es por tal motivo, que a partir de este momento y no antes, se considera que el proyecto entra en una etapa plena de producción para efectos jurídicos.

La PMO se encuentra regulada en el artículo $38^{\circ}$ de la $\mathrm{LGM}^{22}$, y exige (bajo el texto vigente modificado por Decreto Legislativo $\mathrm{N}^{\circ} 1054$ ) una producción no menor a la Unidad Impositiva Tributaria (UIT) o un porcentaje de ella, por año y por hectárea otorgada. Es decir, actualmente la PMO exigida depende del factor área de la concesión.

${ }^{22}$ De acuerdo a lo previsto por el artículo $38^{\circ}$ de la LGM vigente:

La producción no podrá ser inferior al equivalente a una UIT por año y por hectárea otorgada, tratándose de sustancias metálicas y del equivalente al 10\% de la UIT por año y por hectárea otorgada, tratándose de sustancias no metálicas. En el caso de pequeños productores mineros la producción no podrá ser inferior al equivalente a 10\% de la UIT por año y por hectárea otorgada en caso de sustancias metálicas y de $5 \%$ de la UIT por año y por hectárea en el caso de la minería no metálica. Para el caso de productores mineros artesanales la producción no podrá ser inferior al 5\% de la UIT por año y por hectárea otorgada sea cual fuere la sustancia. La producción deberá obtenerse no más tarde del vencimiento del décimo año, computado a partir del año siguiente en que se hubiera otorgado el título de concesión (...). 
Por ejemplo, la norma exige una producción no menor a 1 UIT por año y por hectárea para el caso de las sustancias metálicas. Asimismo, la norma señala que el titular de la concesión deberá obtener la PMO no más tarde del vencimiento del décimo año, computado a partir del año siguiente de otorgado el título de concesión.

Pues bien, como se ha señalado la norma establece como hito para diversos aspectos de su aplicación a la fecha o ejercicio en que "de acuerdo a ley corresponde cumplir con la producción mínima”. Surgen entonces dos posibles interpretaciones:

a) Entender que la fecha en que de acuerdo a ley corresponde cumplir con la PMO es la fecha en que efectivamente se llegue a producir un determinado monto en soles por hectárea.

b) Entender que la fecha en que de acuerdo a ley corresponde cumplir con la PMO corresponde al décimo año computado a partir del año siguiente de otorgado el título de concesión (independientemente de si se llegó o no efectivamente a cumplir con la producción exigida).

Como señalamos, la norma parte de establecer que el tratamiento previsto en el artículo $74^{\circ}$ de la LGM aplica a lo invertido en prospección y exploración hasta la fecha en que de acuerdo a ley corresponda cumplir con la PMO.

Bajo la primera interpretación, la norma alcanzaría a los desembolsos que se efectúen hasta que se obtenga el grado de producción exigido legalmente y no antes. Este entendimiento responde a que desde un punto de vista jurídico la explotación como tal da inicio una vez que el titular de la actividad minera logra el ingreso mínimo esperado por el Estado y por tanto, todos los gastos de exploración y prospección efectuados con anterioridad a dicho momento reciben un tratamiento específico. Bajo esta lógica, no es relevante que en la realidad la mina haya iniciado operaciones, generado ingresos, o empezado la producción o explotación del mineral, lo que importa para efectos jurídicos es que esa producción sea suficiente y significativa para considerar que la mina ha pasado de una fase preoperativa a una de explotación, y este límite entre una fase y otra está determinado por haber obtenido la producción mínima que exige la ley.

Bajo la segunda interpretación, el tratamiento previsto en el artículo $74^{\circ}$ de la LGM aplicaría a lo invertido en prospección y exploración hasta el décimo año computado a partir del año siguiente de otorgado el título de concesión, se haya iniciado 
o no actividad productiva o se haya llegado o no a la PMO. Consideramos que esta interpretación llevaría a una situación arbitraria e irracional, no tendría sentido tratar las inversiones en prospección y exploración que se realicen hasta el año diez de una manera, y a aquellas que se realicen en el año once de otra, pues no es el paso de los años lo que podría determinar el límite entre un gasto preoperativo de uno efectuado en etapa operativa. El plazo de diez años establecido es un plazo máximo en que el Estado espera lograr una producción por parte del inversionista, pero no un plazo que pueda implicar un corte que justifique un tratamiento tributario diferenciado entre un mismo tipo de gastos si es que la fase preoperativa continúa, o que pueda determinar que aún iniciada la explotación comercial, se siga otorgando un tratamiento que responde a la lógica aplicable a los gastos preoperativos a toda aquella inversión en exploración que continúe hasta el año diez.

Respecto a esta segunda interpretación, cabe mencionar que conforme a lo dispuesto por los artículos $40^{\circ 23}$ y $41^{\circ 24}$ de la LGM (bajo el texto vigente modificado por Decreto Legislativo $\mathrm{N}^{\circ}$ 1054), de no cumplirse con la PMO en el plazo de diez años corresponderá se aplique una penalidad pudiendo el titular mantener la concesión hasta el año quince. Si no llegase a la PMO en este plazo se declarará la caducidad de la concesión, salvo que logre prorrogar su vigencia hasta el año veinte, acreditando que el

\footnotetext{
${ }^{23}$ Según lo dispuesto por el artículo 40 de la LGM:
}

En caso de que no se cumpliese con lo dispuesto en el artículo 38 a partir del primer semestre del undécimo año computado desde el siguiente a aquel en que se hubiere otorgado el título de concesión minera, el concesionario deberá pagar una penalidad equivalente al $10 \%$ de la producción mínima anual exigible por año y por hectárea, hasta el año en que cumpla con la producción mínima anual. La penalidad debe pagarse en forma adicional al derecho de vigencia y abonándose y acreditándose en la misma oportunidad de su pago.

Si continuase el incumplimiento hasta el vencimiento del décimo quinto año de otorgada la concesión minera, se declarará su caducidad.

${ }^{24}$ De acuerdo a lo previsto por el artículo 41 de la LGM:

El concesionario no incurre en causal de caducidad luego del vencimiento del décimo quinto año señalado en el artículo 40 y hasta por un plazo máximo de cinco años no prorrogables, si el incumplimiento de la producción mínima se debe a caso fortuito o fuerza mayor o por algún hecho no imputable al titular de actividad minera debidamente sustentado y aprobado por la autoridad competente.

Asimismo, el concesionario podrá eximirse de la caducidad, dentro del plazo señalado en el párrafo anterior, pagando la penalidad y acreditando además, inversiones equivalentes a no menos diez veces el monto de la penalidad que le corresponda pagar. Para este efecto, el titular minero podrá acreditar inversiones destinadas a las actividades mineras y/o en infraestructura básica de uso público. Esta inversión deberá acreditarse de acuerdo a lo que disponga el Reglamento

Si continuase el incumplimiento hasta el vencimiento del vigésimo año computado a partir del año siguiente en que se otorgó la concesión, se declarará indefectiblemente su caducidad. 
incumplimiento se debió a caso fortuito o fuerza mayor o inversiones por no menos de diez veces el monto de la penalidad. Como vemos, si bien la norma establece que el plazo para llegar a obtener la PMO es de diez años contados a partir del año siguiente de otorgada la concesión, la posibilidad de "prorrogar" el plazo para su cumplimiento ha llevado a cuestionar si hito al que se estaría refiriendo el artículo $74^{\circ}$ de la LGM podría ser de hasta veinte años, posición con la que discrepamos pues entendemos que en todo caso, la norma estaría haciendo referencia al plazo máximo establecido sin que ello implique incurrir en moras o sanciones.

Considerando la falta de claridad de la norma y la discrepancia interpretativa existente, resulta recomendable precisar el texto legislativo para que este señale expresamente que el tratamiento previsto en el artículo $74^{\circ}$ de la LGM aplica a lo invertido en prospección y exploración hasta la fecha en que se cumpla efectivamente $\underline{\text { con la PMO. }}$

\subsubsection{Inicio de la amortización}

De acuerdo a lo previsto en el artículo $74^{\circ}$ de la LGM, la amortización de lo invertido en prospección y exploración se iniciará "a partir del ejercicio en que de acuerdo a ley corresponda cumplir con la PMO”.

Como se ha señalado, existen dos posibles interpretaciones en relación a dicha disposición:

a) Entender que el ejercicio en que de acuerdo a ley corresponde cumplir con la PMO, es aquel en que efectivamente se llegue a producir un determinado monto dinerario por hectárea.

b) Entender que el ejercicio en que de acuerdo a ley corresponde cumplir con la PMO, es el décimo año computado a partir del año siguiente de otorgado el título de concesión (independientemente de si se llegó o no efectivamente a cumplir con la producción exigida).

Consideramos que la primera interpretación responde efectivamente a la finalidad de la norma pues permite tener un correlato entre la deducción de los gastos efectuados con los ingresos que se generen con el efectivo inicio de operaciones bajo el estándar mínimo exigido. Esta interpretación responde a la razón de ser de la norma ("ratio 
legis") y resulta acorde con figura de la amortización durante la vida del depósito minero.

De otro lado, debe quedar claro que bajo este entendimiento el inicio del cómputo de la amortización está marcado por el cumplimiento de la PMO y no por el simple inicio de la producción o explotación, o la obtención de cualquier tipo de ingreso, sea por venta de mineral o por cualquier actividad generadora de rentas como podría ser la enajenación de un activo, la generación de intereses, etc.

Esto se explica porque jurídicamente, es sólo con la PMO que se ejercen plenamente las facultades otorgadas por la concesión, al alcanzar el nivel óptimo en función de una producción fijada administrativamente como producto del control administrativo del desarrollo de la actividad minera. Bajo este entendimiento, antes de la PMO no existe una "explotación” desde un punto de vista jurídico.

Bajo la segunda interpretación, la amortización se iniciaría al décimo año de otorgada la concesión, independientemente de si existe o no producción. Evidentemente bajo este criterio se rompería el correlato que debería existir entre gastos e ingresos dejando sin efecto la finalidad de la amortización.

Considerar que la amortización debe iniciarse en un plazo de diez años sin tener en consideración el inicio efectivo de las operaciones llevaría a una situación arbitraria que desnaturaliza el sentido de la norma y al absurdo de sostener, por ejemplo, que la amortización se debe computar a partir del año diez pese a que la empresa se encuentra en plena fase productiva desde el año seis, con lo cual tendríamos una empresa tributando por una renta que no considera deducciones en contravención del principio de capacidad económica. De igual forma se contraviene este principio si se da inicio a la amortización en el año diez pero se inicia la producción en el año quince, en este caso no sólo se produce un desfase entre el reconocimiento de los gastos y los ingresos, sino que se terminarían generando pérdidas tributarias que no podrían ser compensables en su totalidad.

Ahora bien, no obstante lo antes señalado, al resolver una controversia en torno al método de amortización aplicable, el Tribunal Fiscal se ha pronunciado sobre esta materia alejándose de las dos interpretaciones antes explicadas y considerando que el inicio de la amortización podía darse con la simple "explotación de la concesión", esto es, en forma previa a la PMO. 
Aún cuando el artículo $74^{\circ}$ de la LGM establece expresamente que la amortización se iniciará a partir del ejercicio en que de acuerdo a ley corresponda cumplir con la PMO, para el Tribunal Fiscal resulta admisible el cómputo de la amortización desde un momento previo.

En efecto, bajo el razonamiento del Tribunal Fiscal, si la "explotación de la concesión" se produce antes de la PMO entonces la amortización debía computarse desde que se produce tal explotación. Bajo su entendimiento, nos encontraríamos ante un supuesto de "adelanto de explotación" no previsto por la norma minera, por lo que al no estar regulado por la LGM, resultarían de aplicación las normas generales de la Ley del Impuesto a la Renta. Adicionalmente y para sustentar este entendimiento, se remite a las normas que regulan el inicio del cómputo de la depreciación por desgaste de los bienes.

Así tenemos que a la letra el Tribunal Fiscal señaló lo siguiente en la Resolución $\mathrm{N}^{\circ} 12603-8-2011$ :

(...) en el caso de autos se tiene que la explotación de la concesión se inicio en noviembre de 1998, es decir antes de la oportunidad prevista por el artículo $74^{\circ}$ en concordancia con el artículo $38^{\circ}$ de la Ley General de Minería, advirtiéndose que dicho supuesto (adelanto de la explotación) no fue previsto por la referida norma minera.

Que en tal orden de ideas corresponde tener en cuenta lo dispuesto por la Ley del Impuesto a la Renta -norma general en el presente caso- la misma que reconoce que el agotamiento por desgaste que sufran los bienes materia ya sea de depreciación o amortización, debe computarse a partir del mes en que estos se van afectados por la generación de renta gravada (...).

Que en consecuencia, a tenor de lo dispuesto por la Ley del Impuesto a la Renta, se establece que en el presente caso la amortización debía iniciarse a partir de noviembre de 1998, siguiendo en lo demás el procedimiento indicado en el artículo $74^{\circ}$ del TUO de la Ley General de Minería (...) (subrayado agregado).

No compartimos la posición adoptada por el Tribunal Fiscal en esta Resolución por las siguientes consideraciones:

- La interpretación del Tribunal Fiscal contradice abiertamente lo dispuesto en forma expresa por el artículo $74^{\circ}$ de la LGM que sujeta el inicio de la amortización a la PMO (y no a cualquier producción o el simple inicio de las actividades de explotación). 
- En términos fácticos, el inicio de la explotación de la concesión en todos los casos se dará antes de que se llegue a la PMO, pues esta última implica alcanzar ciertos niveles de producción luego de iniciada la actividad de explotación del mineral. El razonamiento del Tribunal Fiscal sería aplicable a la generalidad de los casos, por lo que no cabe considerar que el supuesto analizado sería un "supuesto no previsto por la norma minera", por el contrario, la norma precisamente está regulando el supuesto en que se inicie la explotación comercial antes de que se llegue a la PMO.

- Al aplicar las normas generales de la Ley del Impuesto a la Renta, el Tribunal Fiscal ha hecho primar las disposiciones una norma de carácter general sobre lo dispuesto por la Ley General de Minería, norma específica que prevé como fecha de inicio de la amortización a la fecha en que se haya llegado a la PMO, vulnerando el Principio de Especialidad de las normas según el cual una norma especial prevalece sobre una norma de carácter general.

- El Tribunal Fiscal ha considerado aplicables las normas del Impuesto a la Renta que regulan el inicio del cómputo de la depreciación por agotamiento o desgaste de los bienes. Consideramos que dichas normas no resultan aplicables al caso de la amortización de los gastos de prospección y exploración minera que obedecen a una "depreciación jurídica" (en función al transcurso del tiempo o la vida de la concesión), y no a una "depreciación económica" (aplicable sobre bienes tangibles en función a su uso, desgaste u obsolescencia).

En esta misma línea, no resulta relevante el mes de inicio de la explotación, sino la distribución del gasto durante el transcurso de la vida de la mina.

En este sentido la Resolución del Tribunal Fiscal N 05349-3-2005, señaló en relación a los gastos preoperativos regulados por el inciso g) del artículo $37^{\circ}$ de la Ley del Impuesto a la Renta, que por su naturaleza de "gastos diferidos" y a diferencia de los activos tangibles, la amortización no se encuentra relacionada con la vida útil del activo fijo, por lo que la amortización se debe efectuar a partir del ejercicio de inicio de la producción, entendiéndose por tal al período comprendido entre el 01 de enero y el 31 de diciembre y en forma proporcional, esto es en partes iguales entre los años del plazo para la amortización y no en el 
mes en el que se inició el uso, norma aplicable para la depreciación del activo fijo (p. 12-13).

Por lo antes señalado y basados en una interpretación teleológica de la norma, somos de la opinión que el inicio de la amortización debe corresponder al ejercicio en que efectivamente el titular de la actividad minera obtenga la PMO esperada por Ley.

Finalmente, por lo explicado y a fin de otorgar claridad a la norma, resulta consideramos recomendable precisar el texto legislativo de manera tal que se deje establecido expresamente y sin lugar a dudas, que el inicio de la amortización a que se refiere el artículo $74^{\circ}$ de la LGM debe darse a partir del ejercicio en que se llegue a producir efectivamente los volúmenes exigidos como PMO por la LGM.

\subsubsection{Plazo de la amortización}

De acuerdo a lo dispuesto por el artículo $74^{\circ}$ de la LGM, la amortización se efectuará en un plazo que el titular de actividad minera determinará en ese momento, en base a la vida probable del depósito, plazo que será calculado teniendo en consideración los siguientes elementos: (i) Las reservas probadas; (ii) Las reservas probables; y, (iii) la producción mínima obligatoria de acuerdo a ley. Agrega que el plazo así establecido deberá ser puesto en conocimiento de la Administración Tributaria al presentar la Declaración Jurada Anual del Impuesto a la Renta correspondiente al ejercicio en que se inicie la amortización, adjuntando el cálculo correspondiente.

En primer término, debemos tener en consideración que la norma prevé que el plazo de amortización se determine en un solo momento previo al inicio de su cómputo. Ese momento corresponde al ejercicio en que de acuerdo a ley corresponde cumplir con la PMO, ejercicio que entendemos corresponde a aquél en que efectivamente se obtenga la producción mínima requerida por la LGM. En tal sentido, el plazo se determinará en función a las variables existentes en dicho momento. Siendo ello así, el plazo en función de la vida del depósito se establece como un plazo proyectado, estimativo y probable, pero no responde a un plazo real.

El plazo de amortización así determinado es considerado un plazo fijo, no variable y no sujeto a modificaciones, y debe ser puesto en conocimiento de la Administración Tributaria mediante la Declaración Jurada Anual del Impuesto a la 
Renta que corresponda al ejercicio en que se haya dado inicio a la amortización, esto es, al ejercicio en que se cumpla con la PMO, adjuntándose el cálculo correspondiente.

La norma no ha previsto la posibilidad de que el contribuyente modifique el plazo como consecuencia de la verificación o corrección de sus estimaciones, por ejemplo, con la presentación de una Declaración Jurada Rectificatoria. De igual forma, no se ha previsto que el plazo pueda ser variado en el transcurso del tiempo en función al hallazgo de nuevas reservas o a la extinción de las mismas antes del plazo ya determinado. El único supuesto que la norma admite para modificar el plazo de amortización inicialmente fijado, es el de la incorporación o exclusión de una concesión en una Unidad Económica Administrativa (UEA) regulado en el artículo $12^{\circ}$ del Reglamento del Título Noveno ${ }^{25}$.

Sobre el particular, el Tribunal Fiscal en la Resolución $N^{\circ}$ 12603-8-2011 ha manifestado lo siguiente:

Que de lo expuesto se colige entonces que el plazo se determina en un único momento y es el que debe considerarse para amortizar el valor de la concesión a lo largo de la vida de la mina, siendo que salvo el caso del supuesto de la incorporación o exclusión de una concesión en una Unidad Económica Administrativa previsto en el artículo $12^{\circ}$ del Reglamento, no se prevé normativamente otro supuesto de modificación del plazo de amortización establecido conforme al artículo $74^{\circ}$.

De otro lado, entendemos que la comunicación a la que hace referencia la norma en comentario tiene efectos informativos y no constitutivos; no obstante, debe tenerse presente que en un caso referido a la comunicación sobre deducción de gastos de desarrollo regulada en el artículo $75^{\circ}$ de la LGM, el Tribunal Fiscal resolvió mediante la Resolución $\mathrm{N}^{\circ}$ 21753-11-2012 desconociendo el monto de la amortización al considerar que la comunicación se efectuó con posterioridad a su cómputo, como si

\footnotetext{
${ }^{25}$ De acuerdo a lo previsto por el artículo $12^{\circ}$ del Reglamento del Título Noveno:
}

Artículo 12.- (...) Si una concesión minera se incluyera en una Unidad Económica Administrativa una vez iniciado el plazo de amortización del valor de adquisición o de los gastos de exploración en que se hubiera incurrido, el plazo de amortización deberá reajustarse en base al que le corresponda como integrante de la Unidad.

Los plazos de amortización, tratándose de Unidades Económico Administrativas se reajustarán al cierre de cada ejercicio, considerando la disminución o aumento de reservas probadas y probables que sufra la Unidad como resultado de la inclusión o exclusión de una o más concesiones. 
efectivamente tal comunicación fuese un acto constitutivo del derecho a amortizar los gastos.

Ahora bien, como se ha señalado a fin de fijar el plazo de amortización se deben tener en consideración los siguientes elementos: (i) las reservas probadas; (ii) las reservas probables; y, (iii) la producción mínima obligatoria de acuerdo a ley.

Las reservas probadas son aquellas respecto de las cuáles se ha comprobado su existencia mientras que las probables son aquellas que se encuentran sujetas a comprobación o cuantificación. Así, el plazo de amortización se fija en principio conforme a la proyección estimada de reservas del proyecto.

Asimismo, la vida de un depósito minero no sólo se encuentra en función a la magnitud de las reservas, sino que el período de explotación dependerá también de la capacidad del productor minero en explotar dichas reservas, es decir, la vida del depósito depende además de las reservas del factor producción. La norma ha establecido que la producción a tomarse en consideración para efectuar el cálculo del plazo de amortización es la "producción mínima obligatoria de acuerdo a ley".

En relación a esta disposición han surgido las siguientes interpretaciones:

a) Interpretación literal: para calcular el plazo de amortización se considera que la producción de la mina será equivalente a la PMO establecida en la LGM. Bajo las normas vigentes a fin de proyectar la vida probable del depósito se tomaría en consideración una producción de 1 UIT por hectárea. En este caso, el plazo de amortización se determinaría según la siguiente fórmula:

$$
\text { Plazo }=\underline{\text { Reservas }}
$$

\section{PMO}

b) Ratio legis: Para calcular el plazo de amortización se considera que la producción de la mina corresponderá a la producción estimada anual (PEA) según estudios técnicos realizados al iniciar la producción. En este caso, el plazo de amortización se determinaría según la siguiente fórmula:

$$
\text { Plazo }=\underline{\text { Reservas }}
$$


Bajo la primera de las interpretaciones, tenemos que el plazo de amortización se fijaría considerando un nivel de producción ficticio que no reflejaría la vida real del depósito minero. Este nivel de producción ficto supondría que la mina se explote al mínimo nivel aceptable para efectos jurídicos en forma constante hasta que se consuma el depósito minero. Tenemos entonces que aplicando como denominador la PMO, el plazo para la amortización será bastante extenso y no se condecirá con la vida de la mina y por tanto, tampoco respetará la correlación de gastos con ingresos que se busca con la amortización del gasto.

El plazo de amortización bajo esta primera interpretación estará condicionado por el área de la concesión dado que la PMO se fija en función de un monto determinado por hectárea. Así mientras más extensa sea la concesión más corto será el plazo de amortización, independientemente del nivel de producción que esta tenga. Sobre este particular De la Vega Rengifo (2014) señala:

El único escenario ideal para engarzar la vida probable real con la señalada por la norma será aquel en que la concesión esté conformada por áreas extensas, de modo que la PMO aumente, trayendo como consecuencia un plazo de amortización más corto (p. 156).

Bajo la segunda interpretación, tenemos que el plazo de amortización se fijaría considerando un nivel de producción real estimado y proyectado al futuro que buscaría reflejar el plazo de vida real del depósito minero. Este nivel de producción obedecería a estudios técnicos que recogerían los estimados de posible extracción de mineral bajo las técnicas a emplearse y las características propias de la mina. Tenemos entonces que aplicando como denominador de la fórmula a la PEA, el plazo para la amortización será un plazo proyectado según estimaciones de producción reales que acerque los cálculos a la real vida probable del depósito minero, permitiendo un mayor correlato entre gastos con ingresos.

Esta segunda interpretación que admite calcular el plazo de amortización considerando una producción estimada real, tiene sustento en lo dispuesto por el artículo $12^{\circ}$ del Reglamento del Título Noveno, norma que establece que el plazo de amortización debe tener en consideración la producción anual ${ }^{26}$, entendiendo que este

${ }^{26}$ De acuerdo a lo dispuesto por el artículo $12^{\circ}$ del Reglamento del Título Noveno:

En caso que el titular de actividad minera agrupe sus concesiones mineras en unidades económicas administrativas, el plazo de amortización del valor de adquisición de las concesiones 
término hace referencia a la producción REAL anual. Bajo este criterio la referencia del artículo $74^{\circ}$ de la LGM a la PMO se limitaría a hacer hincapié en que al calcular la vida probable del depósito se debe considerar un factor producción que en ningún caso podría ser menor al exigido por ley. Quienes han sostenido esta posición señalan que la referencia a la PMO de ningún modo podría exigir que se calcule el plazo de la vida de la mina partiendo de la premisa de que esta sólo podría producir el mínimo legal exigible y no más, pues tal entendimiento iría contra la finalidad de la norma la lógica para la cual fue creada y la figura jurídica de la amortización.

Consideramos que esta segunda interpretación resulta más razonable porque permite que el plazo de amortización sea más acorde con la vida probable del depósito (De la Vega Rengifo, 2014, p. 157). No obstante ello, el Tribunal Fiscal ha adoptado la interpretación literal de la norma, y por tanto, ligado el plazo de amortización al supuesto ficticio de una mina que produce al mínimo nivel exigido legalmente. Así, en la Resolución N 12603-8-2011 ha señalado lo siguiente:

(...) que como se aprecia, la norma fija un elemento objetivo para la determinación del plazo, consistente en la producción mínima obligatoria de acuerdo a ley, independientemente de la producción real que pudiera obtenerse, lo que, de acuerdo al texto antes citado de la ley, no es tomado en cuenta.

(...) que sólo en el supuesto de que el artículo $74^{\circ}$ no hubiera señalado de manera expresa el que a efectos de establecer la vida probable del depósito, se debía tomar en cuenta la producción mínima obligatoria establecida en la ley, o si hubiera indicado que 'cuando menos' se tomará tal producción mínima obligatoria, se podría concluir como lo hace la recurrente, que la expresión vida probable del depósito estaba en función de las reservas probadas y probables y de la capacidad de producción real del titular y se hubiere estado bajo una amortización variable; sin embargo, no siendo el caso, dado que el artículo $74^{\circ}$ es claro y categórico en indicar que la vida probable del depósito se calcula tomando en cuenta las reservas probadas y probables y la producción mínima obligatoria de acuerdo a ley, no resulta válida la conclusión a la que arriba la recurrente". (Subrayado agregado).

se determinará en base a las reservas probadas y probables de la Unidad y a la producción anual de ella.

Igual norma se aplicará para determinar el plazo de amortización de los gastos de exploración en que se incurra (...) (subrayado agregado). 
El Tribunal Fiscal no ha tomado en cuenta que el Decreto Legislativo $\mathrm{N}^{\circ} 109$, Ley General de Minería vigente hasta 1991, regulaba un sistema distinto para determinar el valor de la producción mínima anual, pues fijaba dicho estándar en función a la reserva probada o probable y la inversión simultánea tendente al reemplazo de la reserva extraída, por lo que la producción mínima se encontraba directamente vinculada a la reserva del mineral y no a montos fijos de acuerdo al área de la concesión como sucede en la actualidad, por lo que una interpretación literal de la norma teniendo en consideración sólo la redacción actual se contrapone a la finalidad y razonabilidad de la misma.

Ahora bien, conforme a lo analizado, el plazo de amortización de los gastos efectuados en etapa preoperativa debería condecirse efectivamente con la vida del depósito minero de tal manera que exista una adecuada correlación entre gastos e ingresos y se respete la capacidad contributiva del inversionista. Asimismo, que para lograr este fin, el plazo de la vida de la mina no podría fijarse en función de variables irreales o ficticias, sino tendría que corresponder a la realidad.

En este sentido, el cálculo del plazo de amortización debería tener en consideración las reservas probadas y probables, y también el factor producción real, el mismo que a su vez, depende de la capacidad de producción del inversionista, de la inversión que éste realice, del uso de mejor tecnología, o de las propias condiciones de explotación.

En mérito de ello, y teniendo en consideración las características especiales de la actividad minera, convendría establecer un plazo de amortización variable en el tiempo que tome en cuenta los incrementos o decrementos de reservas o la mayor o menor producción, esto es, que tenga en consideración año a año tanto las variaciones en las reservas como en los niveles de producción o explotación.

No encontramos razonable ni propio de la naturaleza de la actividad minera, establecer a priori un plazo de amortización fijo e inamovible que finalmente no se condiga con la vida real del depósito minero ni permita una asociación idónea de los gastos con los ingresos que se vayan generando a lo largo del tiempo, y mucho menos, establecer plazos a priori que tomen en cuenta una producción ficticia que sólo lleva a retrasar la recuperación del gasto creando un escenario que desincentiva al inversionista desde el punto de vista fiscal. 


\subsubsection{Método de amortización}

En el caso concreto de la amortización de los gastos de prospección y exploración minera son dos los posibles métodos de amortización aplicables:

a) El método de amortización lineal, mediante el cual los gastos se amortizan en función a un plazo fijado y determinado, y se deducen anualmente en función a un porcentaje constante.

b) El método de unidades de producción, mediante el cual los gastos se amortizan en función al nivel de producción a través de la deducción anual de un porcentaje variable o ratio de amortización que resulta de comparar la producción versus las reservas existentes.

La norma no hace mención al método de amortización aplicable en forma expresa; sin embargo, considerando que el plazo de amortización se determina en una oportunidad específica y bajo las circunstancias presentes en dicho momento, y asimismo, en la medida que se prevé que dicho plazo no sería variable ni modificable, nos encontraríamos en el escenario de una amortización que se da en función de un plazo fijo y un ratio de deducción constante, características propias del método de amortización lineal.

Bajo este entendimiento, si las reservas varían en el tiempo (por nuevos descubrimientos por ejemplo), el plazo y porcentaje de amortización no variaría. Asimismo, si los niveles de producción a lo largo de la vida de la mina se incrementan (por ejemplo por el descubrimiento de nueva tecnología que eleva el grado de producción), o disminuyen (como ha sucedido con motivo de la drástica caída del precio del mineral que implicó un retraso en los niveles de inversión), el ratio de amortización no se vería afectado. Como puede verse, la amortización lineal no toma en consideración las variaciones en los niveles de reserva ni producción ni tampoco el ciclo natural de la explotación de un depósito minero, que es creciente al inicio de las operaciones y decreciente en la última etapa.

El Tribunal Fiscal se ha pronunciado en relación al método de amortización recogido en el artículo $74^{\circ}$ de la LGM señalando que este es lineal. Así, en la Resolución $N^{\circ}$ 12603-8-2011 manifestó lo siguiente: 
Que teniendo en cuenta que para determinar la amortización de la concesión, la norma minera ha relacionado el valor de la adquisición de la concesión y su vida útil, y ha fijado que esta se calcula tomando en cuenta reservas probadas y probables y la producción mínima obligatoria de acuerdo a ley, lo que arroja un número de años y no un monto de producción, aún cuando de manera expresa no se haya indicado que el método de amortización es el de línea recta, por la descripción del procedimiento que se consigna en el artículo 74 del TUO de la Ley General de Minería, se concluye que ese es el método adoptado por la Ley General de Minería.

Que en consecuencia, el Artículo 74 no contempla una amortización variable en función a producción real, como alega la recurrente, sino una amortización lineal en función a la vida útil determinada bajo las reservas probadas y probables y la producción mínima obligatoria. (Subrayado agregado).

Ahora bien, cabe preguntarnos ¿es el método lineal el más apropiado para amortizar las inversiones en prospección y exploración mineras efectuadas en etapa preoperativa? ¿Acaso dicho método cumple con la finalidad de la amortización que es diferir el gasto preoperativo para que exista una correlación entre los gastos y los ingresos futuros con los cuales se vinculan?

Consideramos que el método de amortización lineal no resulta el método más apropiado para ello y que es el método de unidades de producción el que cumple mejor tal finalidad. En efecto, el método de amortización mediante unidades de producción permite asignar o distribuir los gastos a lo largo de los períodos en que se produzcan los beneficios teniendo en consideración los niveles reales de producción minera. Si bien éste método resulta de compleja aplicación, es el más idóneo para determinar la vida de un proyecto minero, y en general, el más apropiado para las actividades extractivas. No puede perderse de vista que en la actividad minera la vida del yacimiento está condicionada a la mayor o menor producción del ejercicio. En esta misma línea Reig (2001), al analizar la normativa argentina ha manifestado que:

(...) para la amortización de bienes agotables - minas, canteras, bosques y bienes análogos, según los menciona el art. 75 de la ley-, no se señala como método general aplicable el lineal o directo, dado que la pérdida del valor se origina en el agotamiento o consumo de la sustancia productora de la renta. Resulta así que el método más indicado, como sostiene la doctrina contable, es el de amortizarlos en función de las unidades de producción. Este sistema adopta la ley, pues admite que se amortice proporcionalmente al agotamiento y en función de las unidades extraídas. El valor original a considerar, 
para minas, canteras y similares, es el precio de costo acrecido en los gastos incurridos para obtener la concesión, según lo expresa dicha norma legal. (p. 515).

En efecto la vida del depósito minero depende de la producción o esfuerzo y capacidad para obtener el mineral, así, ante mayor inversión o trabajo la vida del depósito será menor. A modo de ejemplo, tenemos el caso de dos proyectos en los que se ha estimado reservas para diez años; sin embargo; una de ellas realiza una mayor inversión logrando culminar con la explotación en un plazo de siete años. De amortizarse el gasto en función a un método lineal, ambas empresas mineras amortizarían lo invertido en prospección y exploración en diez años pese a que una de ellas explotó el yacimiento sólo en siete. Tal posición nos llevaría al absurdo de sostener que si un inversionista es más eficiente no podría aplicar el saldo de la amortización al que tiene derecho contra sus ingresos. Por el contrario, si el inversionista es menos eficiente en su producción, podrá amortizar el gasto en un período menor al previsto, generando una disociación entre los gastos y los ingresos y la posibilidad de pagar un menor Impuesto a la Renta en los primeros años como premio a su falta de productividad.

Siendo ello así, consideramos recomendable que se modifique la norma para admitir la amortización bajo el método de unidades de producción, pues es éste el método que permite la asociación entre gastos e ingresos y por tanto, una tributación en base a la capacidad contributiva del sujeto; sin perjuicio de que ello permitiría uniformizar el tratamiento tributario con el financiero pues es este el método primigenio utilizado por la contabilidad para la amortización del activo de exploración minera.

Este mismo planteamiento fue efectuado por la Relatoría General de las VII Jornadas Nacionales de Tributación de la Asociación Fiscal Internacional (IFA) Grupo Peruano al recomendar lo siguiente:

Modificar los artículos $74^{\circ}$ y $75^{\circ}$ del Texto Único Ordenado de la Ley General de Minería para permitir la amortización de los gastos de exploración y desarrollo, en base al método contable de unidades de producción, como método alternativo de amortización de dichos gastos (Rodríguez Dueñas, 2002, p. 17).

Asimismo, tenemos que en nuestra legislación interna la Ley Orgánica de Hidrocarburos admite la amortización en función al método de unidades productivas, así tenemos que el artículo $53^{\circ}$ de dicha norma señala lo siguiente: 
Los gastos de exploración y desarrollo así como las inversiones que realicen los Contratistas hasta la fecha en que se inicie la extracción comercial de Hidrocarburos, incluyendo el costo de los pozos, serán acumulados a una cuenta cuyo monto, a opción del Contratista y respecto de cada Contrato, se amortizará de acuerdo con cualesquiera de los dos métodos o procedimientos siguientes:

a) En base a la unidad de producción; $\mathrm{o}$,

b) Mediante la amortización lineal, deduciéndolos en porciones iguales, durante un período no menor de cinco (5) ejercicios anuales

Asimismo, y al igual que en el caso del sector hidrocarburos, convendría mantener la opción de amortizar lo invertido en prospección y exploración minera mediante la amortización lineal y proporcional en un periodo no menor de cinco ejercicios, pues esta norma constituye un importante incentivo fiscal para las actividades de exploración que permite acelerar la amortización y diferir el pago del Impuesto a la Renta en el tiempo.

En adición, tenemos que la mayor parte de países recogen en su legislación el método de unidades de producción para la amortización del activo de exploración y que países que buscan otorgar incentivos fiscales a las actividades de exploración minera han recogido la regla de amortización lineal y acelerada, como por ejemplo la legislación colombiana, que en el artículo $143^{\circ}$ de su Estatuto Tributario establece:

(...) Cuando se trate de los costos de adquisición o exploración y explotación de recursos naturales no renovables, la amortización podrá hacerse con base en el sistema de estimación técnica de costo de unidades de operación o por el de amortización en línea recta en un término no inferior a cinco (5) años (...).

Teniendo en consideración que el método de amortización de unidades de producción es el método más adecuado para la deducción de los gastos preoperativos mineros pues tiene en consideración la mayor o menor producción que determina el plazo de la vida de la mina, la misma que es variable a lo largo del tiempo y que refleja por consiguiente una correlación consistente entre los gastos y los beneficios futuros asociados a estos, y asimismo, teniendo en cuenta que la norma que admite la amortización lineal en forma acelerada de las inversiones en prospección y exploración constituye un incentivo fiscal para el inversionista minero que fomenta el desarrollo de actividades de exploración, proponemos modificar el artículo $74^{\circ}$ de la LGM a fin de admitir ambos métodos de amortización. 


\subsection{Segunda opción: Deducción del gasto en el ejercicio en que se "incurra"}

De acuerdo a lo señalado por el artículo $74^{\circ}$ de la LGM, lo invertido en prospección y exploración hasta la fecha en que de acuerdo a la ley corresponda cumplir con la producción mínima, podrá amortizarse en un plazo que se determine en base a la vida probable del depósito, "salvo que se opte por deducir lo gastado prospección y/o exploración en el ejercicio en que se incurra en dichos gastos". En relación a dicho dispositivo, han surgido dos posibles interpretaciones:

a) Se considera que el "incurrido" hace referencia al ejercicio de desembolso efectivo, constituyendo por tanto una excepción a la aplicación del Principio de Devengado y al criterio de correlación de gastos con ingresos.

b) De otra parte, la Administración Tributaria ha efectuado acotaciones al considerar que el ejercicio en que se incurre en un gasto debe ser el ejercicio en que se inicia operaciones. Sostiene tal posición en que el criterio de asociación de ingresos con gastos obliga a que los gastos se deduzcan en forma correlativa en el ejercicio en que se genere ingresos. Este criterio interpretativo ha sido aplicado para los gastos preoperativos regulados en el inciso g) del artículo $37^{\circ}$ de la Ley del Impuesto a la Renta.

Sobre el particular, tenemos que el artículo $57^{\circ}$ de la Ley del Impuesto a la Renta establece que los gastos serán deducibles en el ejercicio en que "se devenguen". De otro lado, tenemos que el inciso o) del artículo $37^{\circ}$ de la LIR, así como el artículo $74^{\circ}$ de la LGM establecen que los gastos de exploración serán deducibles en el ejercicio en que "se incurran". De una interpretación literal de las normas, podemos concluir que se están regulando dos supuestos distintos de reconocimiento de gastos, por un lado tenemos la regla general del "devengado", y por otro tenemos una regla específica y de excepción para el reconocimiento de gastos aplicable sólo a los gastos de prospección y exploración minera: "el incurrido".

En efecto, consideramos que si la intención del legislador hubiese sido que "incurrido" signifique lo mismo que "devengado", no hubiese sido necesario que establezca expresamente un criterio de imputación de gastos específico pues sería aplicable el criterio general. 
Ahora bien, ¿con qué finalidad el legislador habría previsto "el incurrido" como regla de imputación para los gastos de prospección y exploración? Pues entendemos que el legislador habría tenido las siguientes consideraciones:

a) Como hemos señalado en el capítulo anterior, el tratamiento tributario recogido en el artículo $74^{\circ}$ de la $\mathrm{LGM}$ es consistente con el tratamiento previsto en las normas contables o financieras. Así, la norma contable, específicamente el criterio de correlación de gastos con ingresos recogido en el Marco Conceptual, admite la posibilidad de deducir gastos en el ejercicio de su desembolso, por lo que NO es correcto afirmar que en aplicación de dicho criterio todos los gastos preoperativos deban diferirse hasta el período en que se generen ingresos. En efecto, la norma contable prevé reconocer gastos en el ejercicio en que se incurran o de su desembolso efectivo en el caso que no haya probabilidad de que estos influyan en la generación de beneficios futuros. Asimismo, también permite reconocer gastos en el ejercicio del desembolso en los casos en que siendo probable la generación de beneficios futuros, no se cumplan con las condiciones para su reconocimiento como activo en el balance, o en el camino se dejen de cumplir tales condiciones.

En el caso específico de los gastos de prospección y exploración minera, la "probabilidad" de que estos influyan en la generación de beneficios futuros es aún incierta, por lo que algunos inversionistas reconocen contablemente como gasto dichos egresos (y no como activo de exploración), hasta tener una mayor certeza sobre la posibilidad de su explotación (por ejemplo con la certificación de existencia de reservas).

Así, la norma contable reconoce razonablemente que un contribuyente opte por deducir los gastos en el ejercicio de desembolso en la medida que no todos los gastos, especialmente los de prospección y exploración minera, derivan (o no existe certeza en que deriven) necesariamente en la generación de ingresos. Siguiendo esta misma lógica contable, el legislador ha previsto esta misma opción para efectos fiscales equiparando de esta manera el tratamiento tributario con el financiero.

b) La deducción en el ejercicio de "lo incurrido", constituiría una norma fiscal de incentivo a las inversiones en exploración. 
En efecto, a una empresa minera que genera rentas y a la vez desarrolla actividades de exploración le resulta conveniente para efectos fiscales poder deducir como gasto las inversiones en exploración y por tanto su Impuesto a la Renta. En tal sentido, la deducción en el ejercicio de desembolso de gastos en prospección y exploración incentivaría fiscalmente la ejecución de nuevas exploraciones en unidades productivas.

De igual manera, resultaría conveniente para una empresa exploratoria que tiene certeza del inicio de operaciones en un corto plazo, deducir el gasto en exploración en el ejercicio en que se incurra en lugar de amortizarlo durante la vida del depósito, pues tal deducción generaría pérdidas tributarias y saldos a favor que podría arrastrar y compensar con la renta que generará en los próximos ejercicios.

En suma, consideramos que el "incurrido" constituye una excepción al "devengado" y por tanto debemos entender que de optar por ello, el gasto podría deducirse en el ejercicio de su desembolso.

Esta conclusión se ve respaldada al analizar el antecedente normativo del inciso o) del artículo $37^{\circ}$ de la Ley del Impuesto a la Renta, recogido en el inciso p) del artículo $38^{\circ}$ del Decreto Supremo $N^{\circ} 287-68-\mathrm{HC}$, (1968), norma que consideraba como gasto deducibles a:

p) Los gastos de exploración en que incurran durante el ejercicio gravable las empresas mineras. Tales gastos podrán deducirse íntegramente en dicho año, o diferirse su amortización para hacerla en razón de un porcentaje anual, en función de la vida probable de la mina, de acuerdo con la certificación de la Dirección General de Minería (...).

Como puede verse el texto de dicha norma es más claro y aúna a la interpretación de que el ejercicio en que se incurre en un gasto es aquel de su desembolso. Sobre esta interpretación se pronunció el Tribunal Fiscal en la Resolución $N^{\circ} 13725$ (1978), señalando lo siguiente:

Que de la interpretación del inc. p) del Art. $38^{\circ}$ antes mencionado resulta que éste establece la procedencia de la deducción de los gastos de exploración en que incurran las empresas mineras y prevé (sic) dos procedimientos para deducirlos: a) cargándolos íntegramente en el ejercicio en el cual se produjeron; o, b) Difiriendo su amortización. 


\section{$(\ldots)$}

Esta interpretación se ampara además en la circunstancia de que la empresa minera no puede conocer necesariamente durante un ejercicio si la mina va a resultar productiva o no, por lo que de aplicarse la interpretación de la Dirección General de Contribuciones llevaría a la inaplicabilidad de la norma en cuanto se refiere a la deducción íntegra de

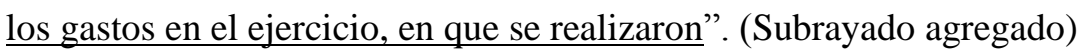

De otro lado y como hemos comentado anteriormente, la Administración Tributaria ha pretendido equiparar el tratamiento tributario de los gastos preoperativos generales, con el de los gastos de prospección y exploración, señalando que así como el inciso g) del artículo $37^{\circ}$ de la Ley del Impuesto a la Renta admite la deducción del gasto en "el primer ejercicio en que se inicien actividades", el artículo $74^{\circ}$ de la LGM admite la deducción del gasto en un solo ejercicio, debiendo entender por éste al ejercicio en que se llegue a la producción mínima legal. Como hemos señalado, a diferencia del inciso g) del artículo $37^{\circ}$ de la Ley del Impuesto al a Renta, la LGM no hace referencia a un "primer ejercicio". Asimismo, la norma tributaria minera prevé un criterio de imputación distinto al de devengado alejándose por tanto del denominado criterio de correlación de gasto con ingreso.

Al interpretar el inciso g) del artículo $37^{\circ}$ de la Ley del Impuesto a la Renta, la Administración Tributaria en su Informe $N^{\circ}$ 062-2009/SUNAT-2B0000, (2009) ha planteado y avalado la distinción entre "primer ejercicio en que se inicie la producción" en contraposición al "ejercicio en que se incurra en el gasto". En tal sentido, la propia Administración reconoce indirectamente que cuando el artículo $74^{\circ}$ de la LGM se refiere al "ejercicio en que se incurra", se está refiriendo al ejercicio de desembolso y no al ejercicio de inicio de actividades. En efecto, según lo expuesto en dicho Informe el "ejercicio en que se incurra en el gasto" constituiría la antípoda al "ejercicio de inicio de producción".

Finalmente, consideramos que esta discusión ha sido zanjada por el Tribunal Fiscal al emitir la Resolución N 18397-10-2013 (2013), la misma que se pronuncia en relación a reparos efectuados por la Administración Tributaria sobre diversos de gastos de exploración deducidos por el contribuyente en el ejercicio de su desembolso. La Administración Tributaria consideró que dichos gastos debieron diferirse y deducirse recién en el ejercicio de la producción mínima legal, sustentando su posición en la 
aplicación del criterio de correlación de gastos con ingresos. Sobre esta controversia el Tribunal Fiscal resolvió de acuerdo a lo siguiente:

(...) se observa que la Administración no cuestiona que (sic) la naturaleza de las erogaciones materia de reparo o que las mismas se hubiesen efectuado en la etapa de exploración, sino la oportunidad de su deducibilidad, esto es, que no corresponda que las mismas incidan en los resultados del ejercicio 2005 sino del ejercicio 2006, al considerar que las respectivas concesiones no habían ingresado a la etapa de producción mínima de conformidad con lo dispuesto en la Ley General de Minería; no obstante, el ente fiscal omite que la recurrente tenía la opción de efectuar la deducción de tales erogaciones en el ejercicio en que se incurren, lo que ésta hizo de acuerdo a ley, correspondiendo en consecuencia levantar el reparo bajo análisis y revocar la resolución apelada en este extremo" (p. 29-30) (subrayado y énfasis agregados). 


\section{CONCLUSIONES}

- El tratamiento tributario aplicable a las inversiones en prospección y exploración minera antes del inicio de la etapa operativa resulta de especial importancia para el inversionista que apuesta por iniciar y desarrollar un proyecto minero, teniendo en consideración el alto riesgo de la operación debido a la falta de certidumbre sobre su éxito o viabilidad. En este contexto, factores como la seguridad jurídica, la certeza y claridad en el tratamiento tributario de dichos desembolsos resultan fundamentales para medir y garantizar el retorno de la inversión.

La política tributaria minera debe tener como objetivo lograr ingresos que permitan al Estado sostener sus cargas públicas, pero también brindar al inversionista un sistema fiscal atractivo que otorgue seguridad jurídica y predictibilidad de las reglas de juego, de manera que se consiga competitividad internacional en la atracción de inversiones en exploración y se asegure la continuidad de la actividad minera, actividad fundamental para la generación de recursos estatales y el desarrollo nacional.

Las normas que regulan el tratamiento tributario de estas inversiones han quedado desfasadas en el tiempo, se han mantenido inalterables durante los últimos treinta años pese a que el sector minero, su importancia, dinamismo y complejidad ha sobrepasado las consideraciones planteadas inicialmente por el legislador. Asimismo, a lo largo de los años hemos sido testigos del surgimiento de diversos criterios interpretativos, discrepancias en su aplicación, así como actuaciones del fisco tendientes a desconocer la deducción de dichos gastos para la determinación del Impuesto a la Renta.

Vemos necesario un análisis de la normativa tributaria vigente así como la elaboración de propuestas normativas que otorguen claridad y predictibilidad en las reglas de juego, dando prevalencia a mecanismos tributarios que permitan incentivar la inversión en exploración y aseguren el crecimiento sostenido de la actividad minera, más aún en la coyuntura actual en la que existe una importante reducción de la inversión en exploración. 
- Son gastos de prospección minera, aquellos desembolsos destinados a la identificación de la zona en donde se encuentra el yacimiento minero a través de la ubicación de anomalías geológicas en la corteza terrestre por medio de indicaciones químicas y físicas medidas con instrumentos y técnicas de precisión.

Son gastos de exploración minera, aquellos desembolsos destinados a la comprobación de existencia de yacimientos minerales, sus dimensiones, ubicación, características, reservas y valores, así como la viabilidad técnica y económica de su explotación.

Los gastos de prospección y exploración minera efectuados antes del inicio de la etapa productiva, son aquellos ejecutados por el titular de la actividad minera que no realiza ninguna actividad de explotación de mineral, ni en el proyecto o concesión en donde explora, ni en otro distinto.

- El tratamiento tributario de los gastos de prospección y exploración minera se encuentra regulado en el inciso o) del artículo $37^{\circ}$ de la Ley del Impuesto a la Renta, norma que establece que los mismos podrán ser deducidos en el ejercicio en que se incurran o deberán ser amortizados en los plazos y condiciones que señale la LGM y sus normas complementarias y reglamentarias.

Por su parte, el artículo $74^{\circ}$ de la LGM, dispone que lo invertido en prospección y exploración hasta la fecha en que de acuerdo a la ley corresponda cumplir con la producción mínima, esto es, durante la etapa preoperativa, podrá amortizarse en un plazo que se determine en base a la vida probable del depósito, salvo que se opte por deducir lo gastado en el ejercicio en que se incurra en dichos gastos.

- El inciso o) del artículo $37^{\circ}$ de la Ley del Impuesto a la Renta hace referencia a "gastos de exploración" mientras que el artículo $74^{\circ}$ de la LGM se refiere a "lo invertido en prospección y exploración". Esta aparente disyuntiva ha generado dos posibles interpretaciones en relación al alcance del tratamiento tributario previsto en el artículo $74^{\circ}$ de la LGM:

a) Interpretar que sólo alcanza a aquellos conceptos que califiquen contablemente como "gasto", por lo que no sería aplicable a los desembolsos que califiquen como "activo" (que es como se registran las inversiones). Entendemos como "gasto" a la disminución del beneficio 
económico en un período contable que afecta sólo a los resultados de dicho ejercicio; o,

b) Interpretar que la referencia a "lo invertido", incluye tanto a gastos como a activos, en tanto que el término "inversión" hace referencia a todo desembolso que tiene relación con beneficios económicos futuros a lo largo de uno o varios años, lo que contablemente es registrado como activo y deducido vía amortización o depreciación.

- Consideramos que existen las siguientes razones y fundamentos para considerar que el tratamiento tributario previsto en el artículo $74^{\circ}$ de la LGM alcanza también a los "activos":

- El inciso o) del artículo $37^{\circ}$ de la Ley del Impuesto a la Renta hace referencia a "gastos de exploración" mientras que el artículo $74^{\circ}$ de la LGM se refiere a "lo invertido en prospección y exploración".

Al hacer referencia a "lo invertido", el artículo $74^{\circ}$ de la LGM alcanza a las partidas que califican como "activos", pues es así como se registran las inversiones o desembolsos que tienen relación con la generación de beneficios futuros.

Asimismo, de una interpretación sistemática de ambas normas, no podría entenderse que el supuesto regulado por la Ley del Impuesto a la Renta se limita a lo que en estricto califica como "gasto", sino que alcanza también a lo que se invierta en forma general, abarcando tanto a gastos como a activos.

- Los desembolsos destinados a la prospección y exploración minera son erogaciones que se efectúan con la expectativa de generar ingresos en el futuro, por lo que para efectos contables tienen la naturaleza de "activos" per se. Carecería de sentido interpretar que el artículo $74^{\circ}$ de la LGM se limita a regular sólo aquellos desembolsos que se registran contablemente como "gasto", pues bajo este entendimiento la norma resultaría inaplicable.

- Entender que el artículo $74^{\circ}$ de la LGM se aplica sólo a aquellos desembolsos que se registran como "gasto", es decir, a aquellos desembolsos cuya naturaleza NO es la de generar beneficios futuros, terminaría por eliminar la finalidad para la cual la norma tributaria fue creada, esto es, regular la deducción de las inversiones en exploración en 
correlación con los ingresos que estas inversiones generen en el futuro, llegando al absurdo de considerar que la amortización del gasto durante el período en que se generen rentas sería aplicable a desembolsos que no conllevaron su generación.

- El legislador ha tenido como finalidad recoger en la norma tributaria la regulación prevista por la norma financiera. Dicha regulación se encuentra recogida en la actualidad por la NIIF 6, norma contable que dispone que los desembolsos en exploración se reconocen como activos para exploración, según lo establezca la política contable de la empresa. Agrega que al establecer esta política se considerará el grado en que los desembolsos puedan estar asociados con el descubrimiento de recursos minerales específicos.

En tal sentido, resulta razonable y consistente, que los desembolsos que tengan vinculación con el descubrimiento de recursos y generación de beneficios futuros se reconozcan contablemente como activo para exploración y se amorticen tanto financiera como tributariamente. Por el contrario, los desembolsos que no tengan vinculación con la generación de beneficios futuros se reconocerían como gasto del ejercicio para efectos contables, mientras que para efectos tributarios se deduciría en el ejercicio en que se incurra en él.

En nuestra legislación interna tenemos una regla similar para la deducción de gastos en exploración de hidrocarburos recogida en el artículo $53^{\circ}$ de la Ley Orgánica de Hidrocarburos (Ley 26221, 1993), norma que se refiere a: "los gastos de exploración y desarrollo así como las inversiones que realicen los Contratistas hasta la fecha en que se inicie la extracción comercial de Hidrocarburos (...)". Al interpretar dicha norma, no cabe que la misma alcanza tanto a "gastos" como a "activos", por lo que bajo el mismo razonamiento, igual interpretación debería aplicarse para la norma tributaria minera.

- Existe una disyuntiva en relación a si el artículo $74^{\circ}$ de la LGM alcanza a aquellas erogaciones que bajo un concepto general califican como "activo fijo", o si por el contrario les es aplicable la deducción vía depreciación prevista en el artículo $38^{\circ}$ de la Ley del Impuesto a la Renta. 
Bajo las consideraciones planteadas en el punto anterior, el artículo $74^{\circ}$ de la LGM alcanzaría también a los "activos fijos" al regular en general a "lo invertido en prospección y exploración" sin hacer distinción alguna entre el tipo de inversión alcanzada.

Suma a esta posición, el que bajo las disposiciones de la NIIF 6, las inversiones se registran como "activos para exploración" y no como "activos fijos", no resultando de aplicación las normas de la NIC 16 ni el registro una depreciación financiera.

No obstante ello, no todos los bienes tangibles que se adquieren durante la exploración se registran o califican como "activos para exploración". En dichos caso sí resultaría de aplicación la NIC 16 y la contabilización financiera de la depreciación, tal es el supuesto de los denominados "activos de soporte" que se caracterizan por no tener una vida útil asociada a la vida del depósito minero.

Tal y como está redactada, la norma no es tajante ni permite determinar un tratamiento tributario claro en relación a los bienes que califican conceptualmente como "activo fijo" (se registren como tal o no), en la medida que no regula su tratamiento en forma expresa, ni limita su aplicación respecto del activo fijo que no tiene relación con la vida útil de la mina.

- En aras de la claridad y seguridad jurídica que debe tener la norma tributaria, consideramos recomendable que el artículo $74^{\circ}$ de la LGM haga referencia en general a "los desembolsos" que realicen los titulares de la actividad minera, de manera tal que tal regulación alcance tanto a las erogaciones que califiquen contablemente como "gasto" como a aquellas que califiquen como "activo" o “inversión”.

Asimismo, la norma debería definir claramente si es que dicha regulación resulta aplicable a los desembolsos que bajo un concepto general califican como "activo fijo", o si por el contrario corresponde su deducción vía depreciación, previendo asimismo un tratamiento específico para aquellos "activos fijos" que con registrados como tal por calificar como "activos de soporte" y cuya vida útil no tiene relación con la vida del depósito minero.

- En una fase previa al inicio de la etapa productiva podemos encontrar gastos de distinta naturaleza a los de prospección y exploración. La distinción entre un tipo de gasto y otro resulta fundamental para determinar el tratamiento tributario aplicable, 
pues mientras la deducción de los gastos de prospección y exploración se rige por la regla específica prevista en el artículo $74^{\circ}$ de la LGM, la deducción de los gastos que no califiquen como de prospección y exploración se regirán por las normas generales de la Ley del Impuesto a la Renta u otras normas especificas.

Además de los gastos de prospección y exploración podemos encontrar a los siguientes: (i) gastos preoperativos generales; (ii) gastos de desarrollo; y, (iii) gastos de cateo. La calificación de los gastos depende de su naturaleza y del destino o finalidad del desembolso de acuerdo a criterios técnicos y especializados.

Sólo calificarán como gastos de prospección y exploración aquellos que desde un punto de vista técnico estén destinados a la ubicación del yacimiento minero, la comprobación de sus características y la viabilidad de su explotación.

A diferencia de estos, los gastos preoperativos generales son gastos de corte administrativo vinculados a la constitución y organización de la sociedad. Estos gastos se rigen por el régimen común del Impuesto a la Renta previsto en el inciso g) del artículo $37^{\circ}$ de la Ley del Impuesto a la Renta y el literal d) de su Reglamento. Las diferencias entre el tratamiento tributario que corresponde a los "gastos preoperativos iniciales" y los gastos de prospección y exploración se describen en la Tabla 3.1

Los gastos de desarrollo son aquellos desembolsos anteriores a la etapa de explotación que tienen como finalidad posibilitar y preparar el acceso al yacimiento minero y su producción. Su tratamiento tributario está previsto en el artículo $75^{\circ}$ de la LGM. Las diferencias entre el tratamiento tributario aplicable a los gastos de prospección y exploración y los gastos de desarrollo se describen en la Tabla 3.2

Los gastos de cateo son aquellos conducentes a poner en evidencia indicios de mineralización por medio de labores mineras elementales, y que supone acciones de búsqueda de mineral bastante preliminares a diferencia de la prospección que supone el uso de métodos y tecnología adicionales. Si bien la LGM distingue el cateo de la prospección, sólo prevé un tratamiento tributario a los gastos de prospección y de exploración, por lo que la deducción de los gastos de cateo se regirá conforme al régimen general previsto en el inciso g) del artículo $37^{\circ}$ de la Ley del Impuesto a la Renta y normas reglamentarias. 
- Consideramos que no se justifica desde un punto de vista técnico y jurídico otorgar un tratamiento tributario disímil a cada tipo de desembolso efectuado antes del inicio de la producción minera dependiendo de su calificación como gasto de cateo, prospección, exploración, desarrollo o gasto administrativo general.

Cabe que todos estos desembolsos sigan el tratamiento previsto en el artículo $74^{\circ}$ de la LGM en tanto se tratan de erogaciones que deben reconocerse vía amortización al influir en la generación de las rentas futuras a obtenerse durante la explotación del yacimiento minero.

Asimismo, cabe que cualquiera de estas erogaciones puedan deducirse en el ejercicio en que se incurrieron sea porque: (i) se trata de desembolsos que no tienen mayor influencia en la generación de rentas futuras, o, (ii) tal opción genera un incentivo tributario al inversionista que obtenga a la par rentas provenientes de otras concesiones o UEA, al poder compensar sus rentas con las pérdidas que se generen como consecuencia de la deducción de las inversiones en las concesiones preoperativas.

En aras de otorgar uniformidad al tratamiento tributario de los desembolsos efectuados antes del inicio de la etapa productiva bajo criterios técnicos que lleven a conciliar el tratamiento contable con el tributario, otorgar incentivos a la inversión en exploración y desarrollo, evitar la generación de contingencias tributarias y dar seguridad jurídica al inversionista en la interpretación y aplicación de las normas, consideramos recomendable una modificación normativa que permita abarcar dentro de los alcances del artículo $74^{\circ}$ de la LGM a todo desembolso efectuado antes del año en que se alcance la producción mínima legal, y que incluya tanto a los gastos de prospección y exploración, como a los gastos de desarrollo, cateo y los preoperativos generales.

- En observancia del Principio de Capacidad Contributiva, los gastos deben deducirse del Impuesto a la Renta aún en el caso que estos se produzcan en un período preoperativo y las rentas se obtengan años después durante una etapa operativa. A tal fin, es indispensable que los gastos preoperativos se asocien y deduzcan de las rentas que se generen en el futuro. El mecanismo que permite asociar y llevar dichos gastos a los ejercicios futuros es el "gasto diferido". 
Bajo la figura de "gasto diferido" subyace el criterio contable de correlación de gastos con ingresos desarrollado en el Marco Conceptual, según el cual los desembolsos que influyan en la generación de rentas futuras se deben reconocer conjuntamente con los ingresos. Cuando los gastos influyen en la generación de beneficios económicos por varios períodos, dicho reconocimiento se efectúa a través de la depreciación o amortización. En caso los gastos no influyan en la obtención de beneficios futuros, deberán deducirse como gasto del ejercicio.

Si bien el concepto de "gasto diferido" y el criterio contable de correlación de gastos con ingresos no ha sido recogido expresamente por la norma tributaria, tanto la doctrina como la jurisprudencia han desarrollado dichos conceptos y previsto su aplicación para el tratamiento tributario de los gastos preoperativos.

- El artículo $74^{\circ}$ de la LGM prevé dos opciones para deducir los gastos de prospección y exploración minera efectuados en etapa preoperativa:

(a) Amortizar lo invertido a partir del ejercicio en que de acuerdo a ley corresponda cumplir con la producción mínima en un plazo determinado en base a la vida probable del depósito, el mismo que se calcula tomando en cuenta las reservas probadas y probables y la producción mínima obligatoria de acuerdo a ley; o,

(b) Deducir lo gastado en el ejercicio en que se incurra en dichos gastos.

- La primera de las opciones para deducir lo invertido en prospección y exploración es la amortización. La amortización es un procedimiento sistemático y racional de asignación o distribución de los gastos que se vinculan con la generación de beneficios futuros en varios ejercicios. La amortización está diseñada para que se reconozca el gasto en los períodos en que se consume o expira el beneficio económico con el que está vinculado, reconocimiento que se realiza en función a la reducción de las expectativas dadas por el transcurso del tiempo, el que puede corresponder por ejemplo al de la vigencia de una concesión o la vida esperada del depósito minero. La amortización corresponde entonces a una "depreciación jurídica" que está basada en el simple paso del tiempo hasta que los beneficios futuros expiren, a diferencia de la "depreciación económica" que toma como base para asignar los gastos el uso y obsolescencia de los bienes corporales. 
- El artículo $74^{\circ}$ de la LGM hace referencia al concepto de Producción Mínima Obligatoria ("PMO") como un hito determinante en su aplicación.

La PMO es una obligación administrativa que exige al titular de la concesión una producción mínima en la concesión otorgada y que tiene como premisa que el otorgamiento de la concesión por parte del Estado obliga a su explotación. Al llegar a la PMO, el titular demuestra que el proyecto minero ha obtenido índices mínimos de rendimiento aceptables. Es por tal motivo, que a partir de este momento y no antes, se considera que el proyecto entra en una etapa plena de producción para efectos jurídicos.

El artículo $38^{\circ}$ de la LGM exige una producción no menor a la Unidad Impositiva Tributaria (UIT) o un porcentaje de ella, por año y por hectárea otorgada, por lo que la PMO exigida depende del factor área de la concesión. Asimismo, la norma señala que el titular de la concesión deberá obtener la PMO no más tarde del vencimiento del décimo año computado a partir del año siguiente de otorgado el título de concesión.

- El tratamiento previsto en el artículo $74^{\circ}$ de la LGM aplica a lo invertido en prospección y exploración hasta la fecha en que de acuerdo a ley corresponda cumplir con la PMO. Sobre el particular han surgido dos posibles interpretaciones:

(a) Entender por tal fecha a aquella en que efectivamente se llegue a producir un determinado monto en soles por hectárea.

(b) Entender por tal fecha al décimo año computado a partir del año siguiente de otorgado el título de concesión (independientemente de si se llegó o no efectivamente a cumplir con la producción exigida).

Considerando la falta de claridad de la norma y la discrepancia interpretativa existente, resulta recomendable precisar el texto legislativo para que este señale expresamente que el tratamiento previsto en el artículo $74^{\circ}$ de la LGM aplica a lo invertido en prospección y exploración hasta la fecha en que se cumpla efectivamente con la PMO.

- En relación al inicio de la amortización, el artículo $74^{\circ}$ de la LGM establece que esta se iniciará "a partir del ejercicio en que de acuerdo a ley corresponda cumplir con la PMO”. Sobre el particular existen dos posibles interpretaciones: 
(a) Entender que la amortización se inicia en el ejercicio en que efectivamente se llegue a producir un determinado monto dinerario por hectárea. Esta interpretación responde a la finalidad de la norma pues permite tener un correlato entre la deducción de los gastos efectuados con los ingresos que se generen con el efectivo inicio de operaciones bajo el estándar mínimo exigido. Esta interpretación toma en consideración que antes de la producción mínima no existe una "explotación” desde un sentido jurídico.

(b) Entender que la amortización se inicia al décimo año computado a partir del año siguiente de otorgado el título de concesión. Bajo esta interpretación, no importaría la existencia o no de actividades productivas, lo que rompería el correlato que debería existir entre gastos e ingresos dejando sin efecto la finalidad de la figura de la amortización.

El Tribunal Fiscal en la Resolución $N^{\circ}$ 12603-8-2011 resolvió esta controversia alejándose de las dos interpretaciones antes explicadas y señalando que el inicio de la amortización podía darse antes de que se logre la PMO en aplicación de lo dispuesto por las normas generales de la Ley del Impuesto a la Renta, haciendo así primar dicha norma sobre lo dispuesto en la LGM.

Consideramos recomendable precisar la norma a fin de señalar expresamente que el inicio de la amortización debe darse a partir del ejercicio en que se llegue a producir efectivamente los volúmenes exigidos como PMO por la LGM.

- En relación al plazo de amortización, el artículo $74^{\circ}$ de la LGM señala que la misma se efectuará en un plazo que el titular de actividad minera determinará en ese momento, en base a la vida probable del depósito, plazo que será calculado teniendo en consideración los siguientes elementos: (i) Las reservas probadas; (ii) Las reservas probables; y, (iii) la producción mínima obligatoria de acuerdo a ley. Agrega que el plazo así establecido deberá ser puesto en conocimiento de la Administración Tributaria al presentar la Declaración Jurada Anual del Impuesto a la Renta correspondiente al ejercicio en que se inicie la amortización, adjuntando el cálculo correspondiente.

La norma prevé que el plazo se determine a priori en un momento previo al inicio de su cómputo en función a las variables existentes a dicha fecha, fijándose por tanto un plazo proyectado, estimativo y probable, que no responde a un plazo real. El plazo 
de amortización así determinado es considerado un plazo fijo, invariable y no sujeto a modificaciones, salvo en el caso de la incorporación o exclusión de una concesión en una UEA.

- La vida del depósito minero depende además de las reservas del factor producción. La norma ha establecido que la producción a tomarse en consideración para efectuar el cálculo del plazo de amortización es la "producción mínima obligatoria de acuerdo a ley”. En relación a esta disposición han surgido las siguientes interpretaciones:

(a) Interpretación literal: toma a la PMO establecida en la LGM, esto es, el valor de la UIT por hectárea. Bajo esta interpretación el plazo se fijaría considerando un nivel de producción ficticio que no reflejaría la vida real del depósito minero y que supone una explotación al mínimo nivel aceptable, determinando un plazo de amortización bastante extenso que no se condecirá con la vida de la mina y por tanto, que no respetará la correlación de gastos con ingresos que se busca con la amortización del gasto.

(b) Ratio legis: toma a la producción estimada anual según estudios técnicos realizados al iniciar la producción. Este plazo se fijaría considerando un nivel de producción real estimada y proyectada al futuro que buscaría reflejar el plazo de vida real del depósito minero.

El Tribunal Fiscal ha adoptado la interpretación literal de la norma, y por tanto, ligado el plazo de amortización al supuesto ficticio de una mina que produce al mínimo nivel exigido legalmente.

Al respecto, consideramos que el plazo de amortización debería condecirse efectivamente con la vida real del depósito minero de tal manera que exista una adecuada correlación entre gastos e ingresos y se respete la capacidad contributiva del inversionista. Para lograr este fin, se tendría que tomar el factor producción real, el mismo que a su vez, dependerá de la capacidad de producción del inversionista, de la inversión que éste realice, del uso de mejor tecnología, o de las propias condiciones de explotación. Teniendo en consideración las características especiales de la actividad minera, convendría establecer un plazo de amortización variable en el tiempo que tome en cuenta los incrementos o decrementos de reservas o la mayor 
o menor producción, esto es, que tenga en consideración año a año tanto las variaciones en las reservas como en los niveles de producción o explotación.

No encontramos razonable ni propio de la naturaleza de la actividad minera, establecer a priori un plazo de amortización fijo e inamovible que finalmente no se condiga con la vida real del depósito minero ni permita una asociación idónea de los gastos con los ingresos que se vayan generando a lo largo del tiempo, y mucho menos, establecer plazos a priori que tomen en cuenta una producción ficticia que sólo lleva a retrasar la recuperación del gasto creando un escenario que desincentiva al inversionista desde el punto de vista fiscal.

- En relación al método de amortización, son dos los posibles métodos aplicables:

(a) El método de amortización lineal, mediante el cual los gastos se amortizan en función a un plazo fijado y determinado, y se deducen anualmente en función a un porcentaje constante.

(b) El método de unidades de producción, mediante el cual los gastos se amortizan en función al nivel de producción a través de la deducción anual de un porcentaje variable o ratio de amortización que resulta de comparar la producción versus las reservas existentes.

Considerando que el plazo de amortización se determina en una oportunidad específica y bajo las circunstancias presentes en dicho momento, y asimismo, en la medida que se prevé que dicho plazo no sería variable ni modificable, nos encontraríamos en el escenario de una amortización lineal, posición que ha sido adoptada por el Tribunal Fiscal en la Resolución N 12603-8-2011.

Consideramos recomendable modificar la norma para admitir la amortización bajo el método de unidades de producción, pues éste es el método más idóneo para determinar la vida de un proyecto minero y es el que resulta más apropiado para las actividades extractivas desde el punto de vista contable y tributario, dado que permite la asociación entre gastos e ingresos y por tanto, una tributación en base a la capacidad contributiva del sujeto.

- La segunda opción para deducir lo invertido en prospección y exploración, consiste en deducir los gastos en el ejercicio en que se incurra en los mismos. En relación a dicho dispositivo, han surgido dos posibles interpretaciones: 
(a) Se considera que el "incurrido" hace referencia al ejercicio de desembolso efectivo, constituyendo una excepción a la aplicación del Principio de Devengado y por ende, al criterio de correlación de gastos con ingresos.

(b) Se considera que el ejercicio en que se incurre en el gasto debe ser el ejercicio en que se inicia operaciones en aplicación del criterio de correlación de gastos con ingresos.

Consideramos que "el incurrido" constituye una regla específica y de excepción al devengado. El legislador habría contemplado la posibilidad de deducir dichos gastos en el período en que se incurre en ellos por las siguientes consideraciones:

- Generar consistencia entre el tratamiento tributario y el tratamiento financiero, teniendo en cuenta que el criterio de correlación de gastos con ingresos admite la posibilidad de deducir gastos en el ejercicio de su desembolso en el caso que no haya probabilidad de que estos influyan en la generación de beneficios futuros.

- La deducción en el ejercicio de "lo incurrido", constituiría una norma fiscal de incentivo a las inversiones en exploración en los casos en que el contribuyente tuviese otras concesiones o UEAs productivas, permitiendo así la compensación de pérdidas de los proyectos exploratorios con las rentas generadas en los proyectos en explotación.

La controversia interpretativa ha sido zanjada por el Tribunal Fiscal, quien se ha pronunciado en el sentido que el contribuyente tenía la opción de efectuar la deducción en el ejercicio en que incurrió en ellos, dejando sin efecto la acotación efectuada por el fisco y que pretendía diferir el gasto al ejercicio de inicio de actividades.

- Finalmente, consideramos recomendable asimilar el tratamiento tributario previsto en la LGM con el previsto por la Ley Orgánica de Hidrocarburos, norma que prevé la amortización bajo dos posibilidades (a opción del contribuyente):

(a) En base a la unidad de producción; o,

(b) Mediante la amortización lineal y proporcional durante un período no menor de cinco ejercicios anuales 
Por un lado, consideramos que el método de unidades de producción resulta el método más adecuado para reconocer los gastos de prospección y exploración, así como el que mejor garantiza el respeto al Principio de Capacidad Contributiva.

Asimismo, resulta conveniente permitir la amortización lineal y proporcional en un periodo no menor de cinco ejercicios, norma que en el sector hidrocarburos ha resultado un importante incentivo fiscal para las actividades de exploración.

De igual manera, es recomendable mantener la norma de deducción en el ejercicio de "lo incurrido", en tanto esta constituye una norma de incentivo a las inversiones en exploración en los casos en que el contribuyente tuviese otras concesiones o UEAs productivas, permitiendo así la compensación de pérdidas de los proyectos exploratorios con las rentas generadas en los proyectos en explotación. 


\section{REFERENCIAS}

Bernstein, L. (1995). Análisis de los Estados Financieros. Madrid. Editorial Irwin/MacGraw-Hill.

Cholvis, F. (1974). Diccionario de Contabilidad. Buenos Aires. Editorial El Ateneo.

Colao Marin, P. (1995). La amortización del inmovilizado en el impuesto sobre sociedades. Pamplona. Aranzandi.

Cooper, W. (2005). Diccionario Kohler para contadores Español - Inglés. México. Editorial LIMUSA.

Decreto Supremo $\mathrm{N}^{\circ}$ 287-68-HC, Ley del Impuesto a la Renta (9 de agosto de 1968). Lima. Ediciones Tiempos Modernos.

Decreto Supremo N 014-92-EM, Texto Único Ordenado de la Ley General de Minería (4 de junio de 1992). Recuperado del sitio de internet del Sistema Peruano de Información Jurídica: http://spij.minjus.gob.pe/libre/main.asp

Decreto Supremo Nº24-93-EM, Reglamento del Título Noveno de la Ley General de Minería, referido a las Garantías y Medidas de Promoción a la Inversión en la actividad minera (7 de junio de 1993). Recuperado del sitio de internet del Sistema Peruano de Información Jurídica: http://spij.minjus.gob.pe/libre/main.asp

Decreto Supremo $N^{\circ}$ 122-94-EF, Reglamento de la Ley del Impuesto a la Renta (21 de Setiembre de 1994). Recuperado del sitio de internet del Sistema Peruano de Información Jurídica: http://spij.minjus.gob.pe/libre/main.asp

Decreto Supremo $N^{\circ} 179-2004-E F$, Texto Único Ordenado de la Ley del Impuesto a la Renta (8 de Diciembre de 2004). Recuperado del sitio de internet del Sistema Peruano de Información Jurídica: http://spij.minjus.gob.pe/libre/main.asp

Decreto Supremo N 042-2005-EM, Texto Único Ordenado de Ley Orgánica de Hidrocarburos (14 de octubre de 2005). Recuperado del sitio de internet del Sistema Peruano de Información Jurídica: http://spij.minjus.gob.pe/libre/main.asp

Decreto Supremo N 133-2013-EF, Texto Único Ordenado del Código Tributario (22 de junio de 2013). Recuperado del sitio de internet del Sistema Peruano de Información Jurídica: http://spij.minjus.gob.pe/libre/main.asp

De la Vega Rengifo, B. (2012). La amortización del valor de la concesión minera y los gastos de exploración. Análisis Tributario, (291), 29- 34. Recuperado de: https://www.aele.com/system/files/archivos/anatrib/12.04\%20AT.pdf 
De la Vega Rengifo, B. (2014). Tributación de inversiones en el sector minería e hidrocarburos. Revista de la Facultad de Derecho de la Pontifica Universidad Católica del Perú, (72), 153-162. Recuperado de:

http://revistas.pucp.edu.pe/index.php/derechopucp/article/viewFile/9774/10185

Estatuto Tributario Colombiano. Recuperado del sitio de internet de la Dirección de Impuestos y Aduanas Nacionales (DIAN):

http://www.dian.gov.co/dian/15servicios.nsf/etributario?OpenView \&Start=1\&C ount $=1000 \&$ Expand $=2 \# 2$

García Montufar, G. (1989). Apuntes de Derecho Minero Común. Lima: Cultural Cuzco S.A.

García Novoa, C. (1994). Las amortizaciones en el Impuesto sobre Sociedades. Madrid. Marcial Pons.

Godoy Fajardo, J. (2008). Amortización de inversiones en exploración y explotación de petróleo y minas. El Impuesto sobre la Renta en el Derecho Comparado. Reflexiones para Colombia, Homenaje al Dr. Juan Rafael bravo Arteaga. Bogotá. ICDT.

Informe $\mathrm{N}^{\circ}$ 035-2007-SUNAT-2B0000 (22 de febrero de 2007). Recuperado del sitio de internet de la SUNAT:

http://www.sunat.gob.pe/legislacion/oficios/2007/oficios/i0352007.htm

Informe $\mathrm{N}^{\circ}$ 62-2009-SUNAT/2B0000, (24 de abril de 2009). Recuperado del sitio de internet de la SUNAT:

http://www.sunat.gob.pe/legislacion/oficios/2009/oficios/i062-2009.pdf

Informe $\mathrm{N}^{\circ}$ 22-2014-SUNAT/5D0000, (2 de julio de 2014). Recuperado del sitio de internet de la SUNAT:

http://www.sunat.gob.pe/legislacion/oficios/2014/informe-oficios/i022-20145D0000.pdf

Informe $\mathrm{N}^{\circ}$ 079-2016-SUNAT/5D0000, (25 de abril de 2016). Recuperado del sitio de internet de la SUNAT:

http://www.sunat.gob.pe/legislacion/oficios/2016/informe-oficios/i079-2016.pdf

Instituto de Ingenieros de Minas del Perú (2016). En 2015 las inversiones en exploración minera en Perú bajaron 28.6\%. Minería On Line. Recuperado de: http://www.mineriaonline.com.pe/pagedeta.asp?idtipo=3\&idpage $=2726$

Lampadia (10 de marzo de 2016). El Perú sigue perdiendo atractivo en inversiones mineras. Recuperado de: http://www.Lampadia.com/analisis/mineria/el-perusigue-perdiendo-atractivo-en-inversiones-mineras/

Ley 27/2014 del Impuesto sobre Sociedades Española (28 de noviembre de 2014).

Recuperado del sitio de internet del Ministerio de Hacienda y Función Pública del Gobierno de España:

http://www.minhafp.gob.es/esES/Normativa\%20y\%20doctrina/Normativa/Pagin as/NormativaResultados.aspx?normativa=:Tributaria:Impuestos\%20sobre\%20so ciedades 
PROESMIN (s.f.) Manual de Minería. Recuperado de:

http://estudiosmineros.com/ManualMineria/Manual_Mineria.pdf

Marco Conceptual para la Información Financiera - versión 2016. Recuperado de:https://www.mef.gob.pe/contenidos/conta_publ/con_nor_co/no_oficializ/ES_ GVT_RedBV2016_conceptual.pdf

Norma Internacional de Contabilidad 1 (NIC 1). Presentación de Estados financieros versión 2016. Recuperado de:

https://www.mef.gob.pe/contenidos/conta_publ/con_nor_co/no_oficializ/nic/ES _GVT_RedBV2016_IAS01.pdf

Norma Internacional de Información Financiera 6 (NIIF 6). Exploración y Evaluación de Recursos Minerales - versión 2016. Recuperado de:

https://www.mef.gob.pe/contenidos/conta_publ/con_nor_co/no_oficializ/niif/ES _GVT_RedBV2016_IFRS06.pdf

Norma Internacional de Contabilidad 16 (NIC 16). Propiedades, Planta y Equipo versión 2016. Recuperado de:

https://www.mef.gob.pe/contenidos/conta_publ/con_nor_co/no_oficializ/nic/ES _GVT_RedBV2016_IAS16.pdf

Notas a los Estados Financieros de Compañía Minera Milpo S.A.A. al 31 de diciembre de 2016. Recuperado de:

http://www.smv.gob.pe/ConsultasP8/temp/Informe\%20EEFF\%20Milpo\%20Sep arado\%204T16.pdf

Notas a los Estados Financieros de Compañía Minera Buenaventura S.A.A. por los años 2016, 2015 y 2014. Recuperado de:

http://www.smv.gob.pe/ConsultasP8/temp/Informacion\%20financiera\%20audita da.pdf

Organismo Supervisor de la Inversión en Energía y Minas (2016). Reporte de análisis económico sectorial Sector Minería, Mercado Mundial, Nacional, efectos derivados y visión de la minería, (6). Recuperado de:

http://www.osinergmin.gob.pe/seccion/centro_documental/Institucional/Estudio s_Economicos/RAES/RAES-Mineria-Agosto-2016-GPAE-OS.pdf

Peumans, H. (1967). Valoración de Proyectos de Inversión. Bilbao. Editorial Deusto.

Red Latinoamericana de Industrias Extractivas (2016). Balance: Transparencia de las industrias extractivas en América Latina durante el superciclo de las materias primas [versión PDF]. Recuperado de: http://propuestaciudadana.org.pe/wpcontent/uploads/2016/02/Balance-transparencia-II.EE_.-en-Am\%C3\%A9ricaLatina-durante-el-superciclo.pdf

Reig, E. (2001). Impuesto a las ganancias. 10 ed. Buenos Aires. Ediciones Macchi.

Resolución del Consejo Normativo de Contabilidad Nº 043-2010-EF/94, Plan Contable General Empresarial (12 de mayo de 2010). Recuperado del sitio de internet del Ministerio de Economía y Finanzas: 
file://C:/Users/Gise/Documents/TESIS/TESIS\%202016/Bibliograf\%C3\%ADa/ Plan\%20Contable\%20General\%20Empresarial.pdf

Resolución de Tribunal Fiscal N 13725 (4 de enero de1978). Recuperado del sitio de internet del Tribunal Fiscal:

http://www.mef.gob.pe/contenidos/tribu_fisc/Tribunal_Fiscal/PDFS/1977/0/197 7-013725-0.PDF

Resolución de Tribunal Fiscal N 00467-5-2003 (29 de enero de 2003). Recuperado del sitio de internet del Tribunal Fiscal:

http://www.mef.gob.pe/contenidos/tribu_fisc/Tribunal_Fiscal/PDFS/2003/5/200 3_5_00467.pdf

Resolución de Tribunal Fiscal N 5349-3-2005 (26 de agosto de 2005). Recuperado del sitio de internet del Tribunal Fiscal:

http://www.mef.gob.pe/contenidos/tribu_fisc/Tribunal_Fiscal/PDFS/2005/3/200 5_3_05349.pdf

Resolución de Tribunal Fiscal Nº3113-1-2006 (7 de junio de 2006). Recuperado del sitio de internet del Tribunal Fiscal:

http://www.mef.gob.pe/contenidos/tribu_fisc/Tribunal_Fiscal/PDFS/2006/1/200 6_1_03113.pdf

Resolución de Tribunal Fiscal Nº 02989-4--2010 (19 de marzo de 2010). Recuperado del sitio de internet del Tribunal Fiscal:

http://www.mef.gob.pe/contenidos/tribu_fisc/Tribunal_Fiscal/PDFS/2006/1/201 0_4_02989.pdf

Resolución de Tribunal Fiscal N 12603-8--2011 (22 de julio de 2011). Recuperado del sitio de internet del Tribunal Fiscal:

http://www.mef.gob.pe/contenidos/tribu_fisc/Tribunal_Fiscal/PDFS/2006/1/201 1_8_12603.pdf

Resolución de Tribunal Fiscal № 21753-11-2012 (20 de diciembre de 2012).

Recuperado del sitio de internet del Tribunal Fiscal:

http://www.mef.gob.pe/contenidos/tribu_fisc/Tribunal_Fiscal/PDFS/2006/1/201 1_8_21753.pdf

Resolución de Tribunal Fiscal º 18397-10-2013 (11 de diciembre de 2013).

Recuperado del sitio de internet del Tribunal Fiscal:

http://www.mef.gob.pe/contenidos/tribu_fisc/Tribunal_Fiscal/PDFS/2013/10/20 13_10_18397.pdf

Rodríguez Dueñas, C. (Junio 2003). Implicancias de las NIC's en la aplicación del Impuesto a la Renta. Cuadernos Tributarios. Revista de la Asociación Fiscal Internacional (IFA) Grupo Peruano del IFA, (28), 1-18.

Rosado Silva, E. (Junio 2003). Implicancias de las normas contables en la aplicación del Impuesto a la Renta acerca de los gastos mineros de exploración, preparación y desarrollo. Cuadernos Tributarios. Revista de la Asociación Fiscal Internacional (IFA) Grupo Peruano del IFA, (28), 119-130. 
Sentencia recaída en el Expediente $\mathrm{N}^{\circ}$ 033-2004-AI/TC (28 de setiembre de 2004).

Recuperado del sitio de internet del Tribunal Constitucional:

http://www.tc.gob.pe/jurisprudencia/2004/00033-2004-AI.html

Sociedad Nacional de Minería, Petróleo y Energía (2016). Web estadística

mineroenergética. Recuperado del sitio de internet de la SNMPE:

http://www.estadisticas-

snmpe.org.pe/EstExt_Principal/EstExt_Pri_Menu.aspx ?x=5591342\&parCodIndi cador $=21 \&$ parCodRubro $=2$

Sociedad Nacional de Minería, Petróleo y Energía (Junio 2017). Entrevista a Juan Luis Kruger: Este 2017 debe ser el punto de inflexión para la industria minera. Desde Adentro. Revista de la SNMPE (SNMPE), 166), 10-12. 


\section{BIBLIOGRAFÍA}

Chumacero, R. (Febrero, 2015). Problemática en torno al tratamiento tributario de los gastos de desarrollo en la actividad minera. Revista del Instituto Peruano de Derecho Tributario, (58), 79 -100.

Colao Marin, P. (1995). La amortización del inmovilizado en el impuesto sobre sociedades. Pamplona. Aranzandi.

De la Vega Rengifo, B. (2012). La amortización del valor de la concesión minera y los gastos de exploración. Análisis Tributario, (291), 29- 34. Recuperado de: https://www.aele.com/system/files/archivos/anatrib/12.04\%20AT.pdf

De la Vega Rengifo, B. (2014). Tributación de inversiones en el sector minería e hidrocarburos. Revista de la Facultad de Derecho de la Pontifica Universidad Católica del Perú, (72), 153-162. Recuperado de: http://revistas.pucp.edu.pe/index.php/derechopucp/article/viewFile/9774/10185

Flury, H. (junio, 1998). Problemas en el marco tributario minero. Revista de Estudios Privados 3(3), 21-24.

García Novoa, C. (1994). Las amortizaciones en el Impuesto sobre Sociedades. Madrid. Marcial Pons.

Godoy Fajardo, J. (2008). Amortización de inversiones en exploración y explotación de petróleo y minas. El Impuesto sobre la Renta en el Derecho Comparado. Reflexiones para Colombia, Homenaje al Dr. Juan Rafael bravo Arteaga. Bogotá. ICDT.

Morón, E. (2007). Competitividad del sector minero, trabajo de investigación de la XXVIII convención Minera. Lima: Universidad del Pacífico.

Rosado Silva, E. (Junio 2003). Implicancias de las normas contables en la aplicación del Impuesto a la Renta acerca de los gastos mineros de exploración, preparación y desarrollo. Cuadernos Tributarios. Revista de la Asociación Fiscal Internacional (IFA) Grupo Peruano del IFA, (28), 119-130.

Seijas, T. (2015). La tributación minera peruana como freno de la competitividad empresarial nacional. Revista Jurídica Docentia et Investigatio, 17 (2), 131-144. Recuperado de http://revistasinvestigacion.unmsm.edu.pe/index.php/derecho/article/view/11569 $/ 10376$ 